\title{
POST-PETROPOLIS: ALBERTA AFTER THE OIL BOOM
}

\author{
By
}

Mohammed Ali Navid-bakhsh

A thesis submitted to the Faculty of Graduate and Postdoctoral Affairs

In partial fulfillment of the requirements for the degree of

Master of Architecture

M.ARCH (Professional)

Azrieli School of Architecture and Urbanism

Carleton university,

Ottawa, Canada

(C) 2016

Mohammed Ali Navid-bakhsh 


\section{Post-Alberta after Petropolís}




\section{Post-Alberta after Petropolis}

Azrieli School of Architecture and Urbanism

Carleton university,

Ottawa, Canada

(C) 2016

M. Ali Navidbakhsh 

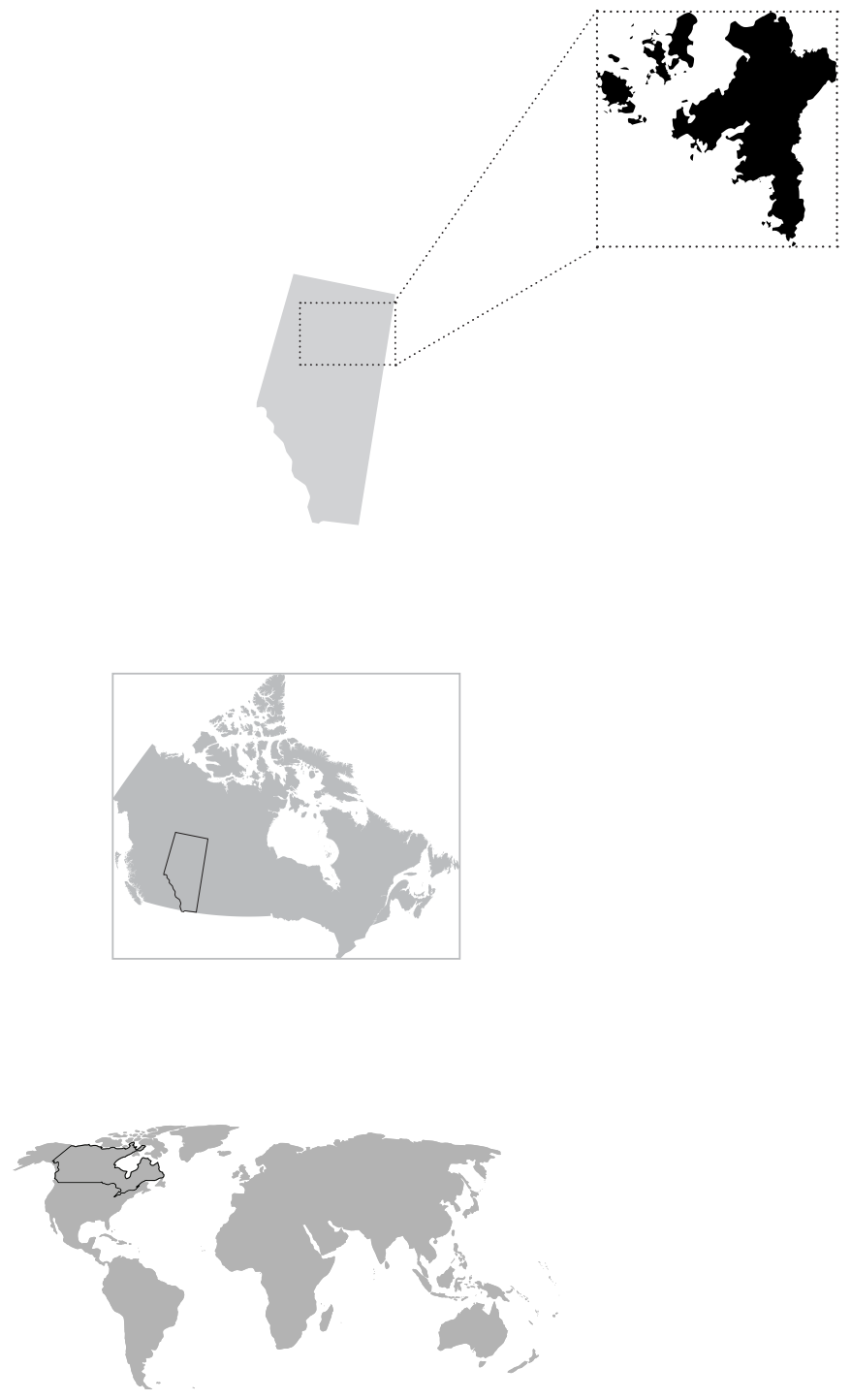


\begin{abstract}
Since the late 1960s, Oil Sand industries continue to scar the land; relentlessly reshaping the topography from wilderness to bulldozed fields in order to suit the strategies of Oil Sand processing and waste storage. This thesis is a counter-factual proposal for the dynamic and fluxing fabric of the Oil Sand industry in Alberta, Canada. Post-Petropolis is the story of conflicting natural and artificial landscapes; a speculative and theoretical proposal that explores today's immense rate of consumption, our precipitous abuse of the landscape, and the planet's scarce resources. Post-Petropolis questions whether it is possible to heal the colossal land scars caused by Oil Sand production with an architectural strategy that envisions the post-oil future of Alberta. Consequently, this theoretical architectural fantasy intends to create a new prehensile reality for Alberta after the oil boom...
\end{abstract}




\section{ACKNOWLEDGEMENTS}

I would like to thank Roger Connah, for all his support and encouragements. I am honoured to be his student and to have experienced true fiction under his advisory. I am very pleased to have been part of his Quintet Group, and to be able to enjoy the sunset at Baklava beach. I was fortunate to have had Claudio Sgrabi as a professor, mentor and most importantly as a theoretical guru. Thank you for the numerous discussions on theory and practice, nothingness and happiness, life and death. Whatever I do will never be enough, would this project be enough? "absolutely not". Thank you to my father, Safar, for always being there to respond to my premature hypothesis and countless conversations riddled with Utopian and dystopian questions. Thank you for all your support; without you I would have never imagined myself here now. An especially great thanks to my brother and sister, Reza and Elmira, who I love dearly and in every moment of this project have been in my mind. Last but not the least; I would like to thank my mother, Masoumeh, and to express my sincere gratitude to her. As always, she has given me exceptional support; she deserves more thanks than I can possibly put into words. I love her for her patience, motivation, and immense knowledge, thank you for all your fabulous stories. 


\section{CONTENTS}

Abstract

Acknowledgements

Prologue

A Reader's Guide to The Fictional Territory

Post-Oil Narrative

Six Stories:

1. Toxic Tourism 12

2. 789D New Suburbia 26

3. Carbon Lust / the Neon City 38

4. Yellow Shrine 51

5. The Little Duck Holocaust 63

6. In Search of Sad Oil 76

From Fiction towards an Architectural Critique 87

Six Archetypes:

1. The Homogeneous Territory - Ephemeral Economy 90

2. Transient Wetlands Territories - Archilocus 99

3. New Alliance Territory - Façades 108

4. Pedagogic Territory - Mercenaries of Architecture 116

5. Bureau of Reclamation - Fort McVegan, Space Frame Farming 125

6. Experimental Utopia - Post-Oil Playgrounds 135

$\begin{array}{ll}\text { Post-Script } & 139\end{array}$

Bibliography 148 


\section{PROLOGUE}

Post-Petropolis speculates on the future state of (Post-) Alberta; a response and critique of the current Oil Sand production trend in competing for the biggest and largest producer of crude oil in Alberta. This fairy tale tells the story of land, in a twelvepart fabular manifesto. Each particular fantasy finds it's rational with surreal and dystopian implications. An absurd ecological assault re-purposes the exhausted lands and glorifies the current irrational state of Alberta. Post-Petropolis is based on the belief that architecture with its visual capacity to comprehend space, people and time can provoke an alternative constituency and promote any utopian ideal. This fabular manifesto is an activist architectural project that postulates a visual dimension to the current environmental dilemma surrounding the Oil Sands in Canada. 
20:02:22
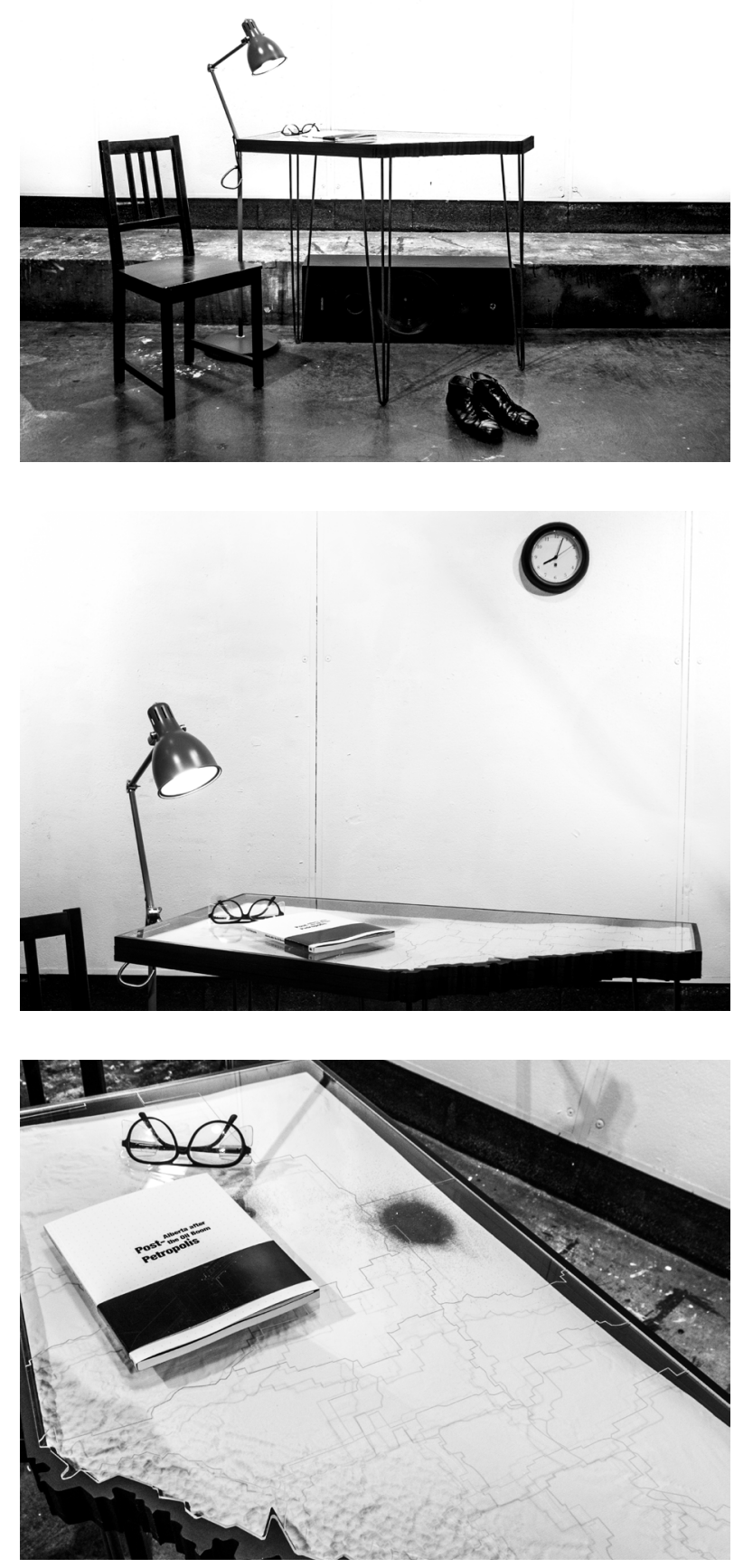


\section{A READER'S GUIDE TO THIS FICTIONAL TERRITORY}

If you find yourself intimidated by the maps, drawings and sequential narrative of this thesis please do not get blasé - it is infectious and simpler than it seems. Perhaps a generous approach might help readers to engage deeper into this thesis. Rather than start at the beginning of each part as in a conventional thesis, simply turn the pages until a drawing or fragment of a tale catches your attention. The story or drawings should be of interest; please skim the passages for other aspects that appear in an intriguing manner. Hopefully, the smog will clear, and the subliminal plot will reveal itself; you will be reading this thesis in the way it was composed; with inspirations from J.G Ballard's short science fiction stories, in particular The Atrocity Exhibition. ${ }^{\text {S Series of }}$ maps and drawings utilize multiple viewpoints to emphasize the collapse of Alberta's landscape. The architectural visualizations (maps and drawings) transcend the existing fabric of Alberta's ecology as the landscape takes new territorial transformation. The large format axonometric drawings reveal the process of land use and the architecture as it shifts to new purpose. To comprehend the context of each fairy tale a section of notes that identify the polemical essence of its narrative will follow. Furthermore, a diaspora section will be the closing part of each chapter and will focuses on presenting frames and visions, examining the past, the present and the possible future of Oil in a global context in order to capture the dynamic struggle between consumption and landscape. 


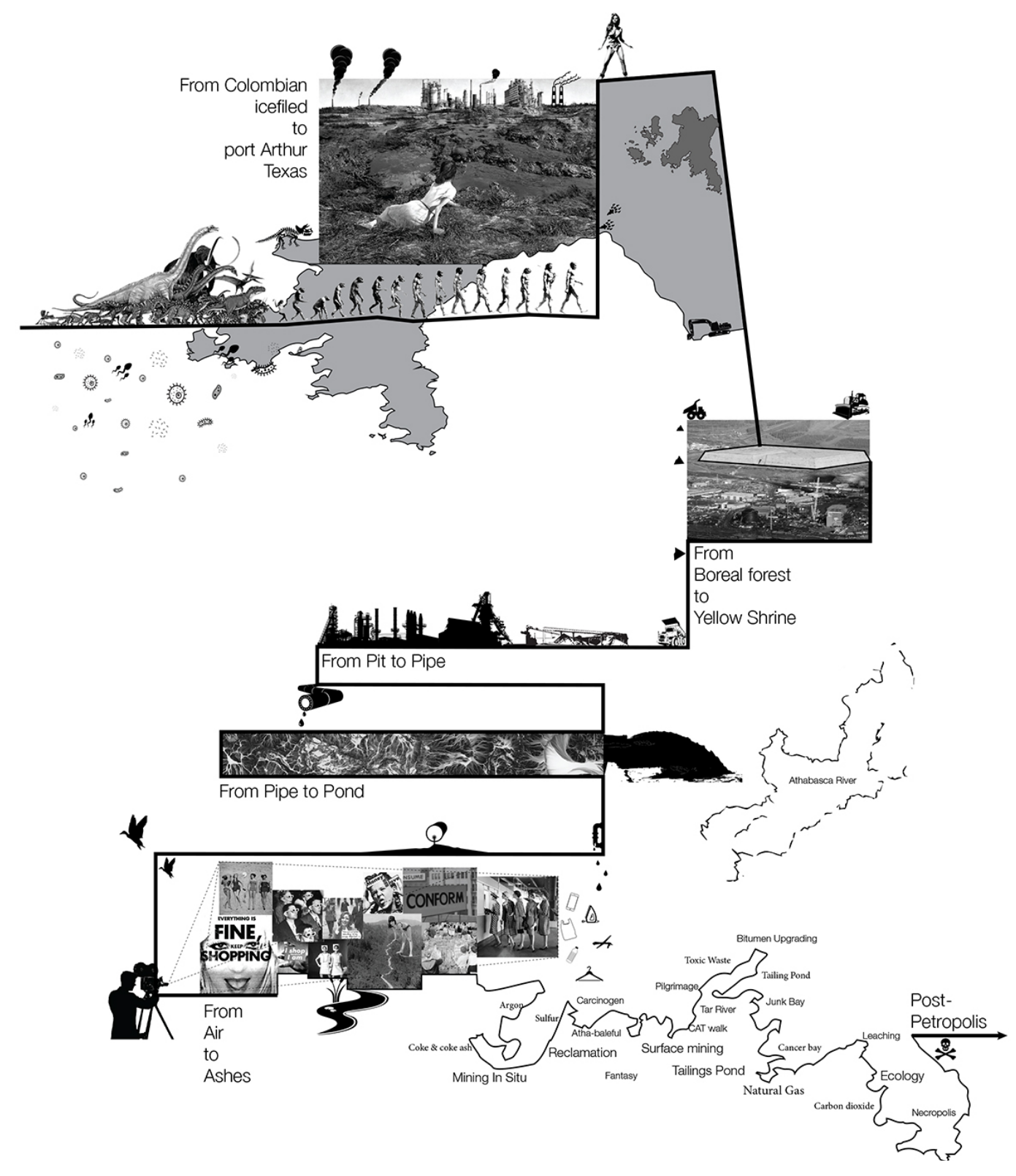




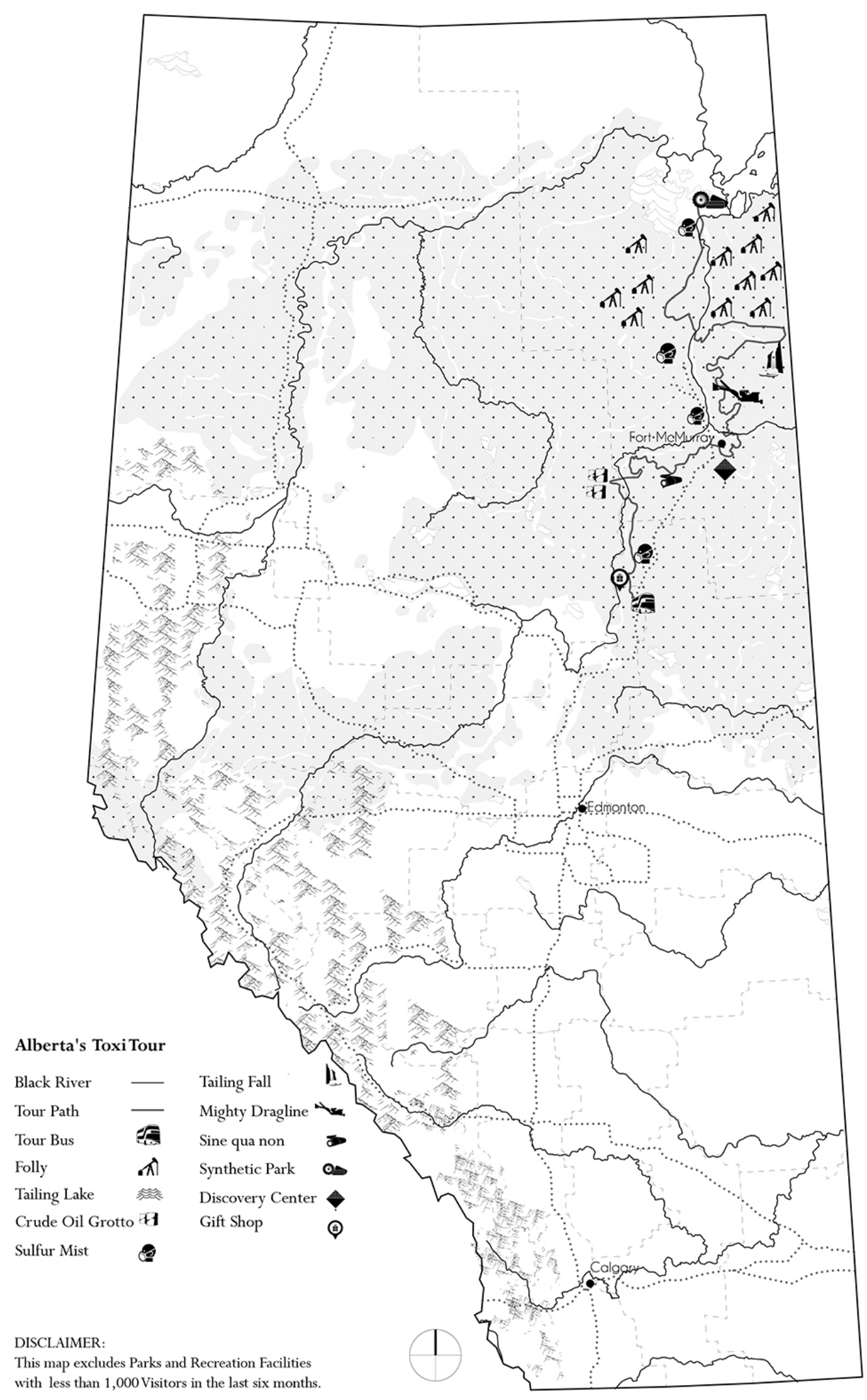




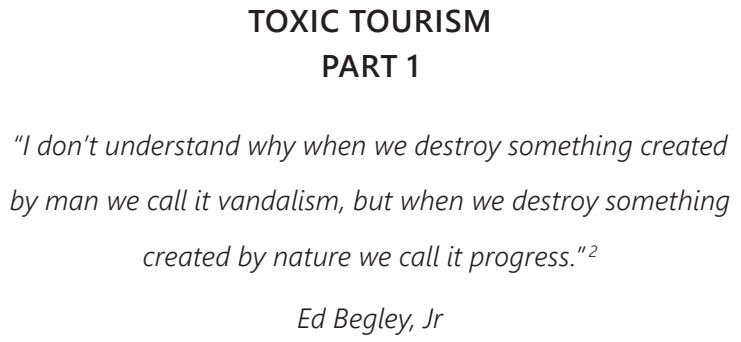

A land, once supporting potato and dairy farms has transformed into super-sized industrial oil sand factories pumping and dumping synthetic crude to the United States. Since the oil bust in 2050, the landscape has transformed again into a monumental tourist destination for delirious and acidic experiences.

Keywords

TOURIST ATTRACTION BEST SUGAR POLLUTION TOURISM

TOXIC TOUR

HAZMAT SUIT

DELIRIOUS EXPERIENCES
ALTERNATIVE

RECLAMATION
BLACK

LAND

$\begin{array}{lrrrr}\text { ALBERTA } & \text { BEST SUGAR } & \text { ALTERNATIVE } & \text { HAZMAT SUIT } & \text { LAND } \\ \text { SCARS } & \text { CAT WALKS } & \text { RECLAMATION } & \text { DELIRIOUS } & \text { EXPERIENCES } \\ \text { SELFIE } & & & & \\ & & & \end{array}$




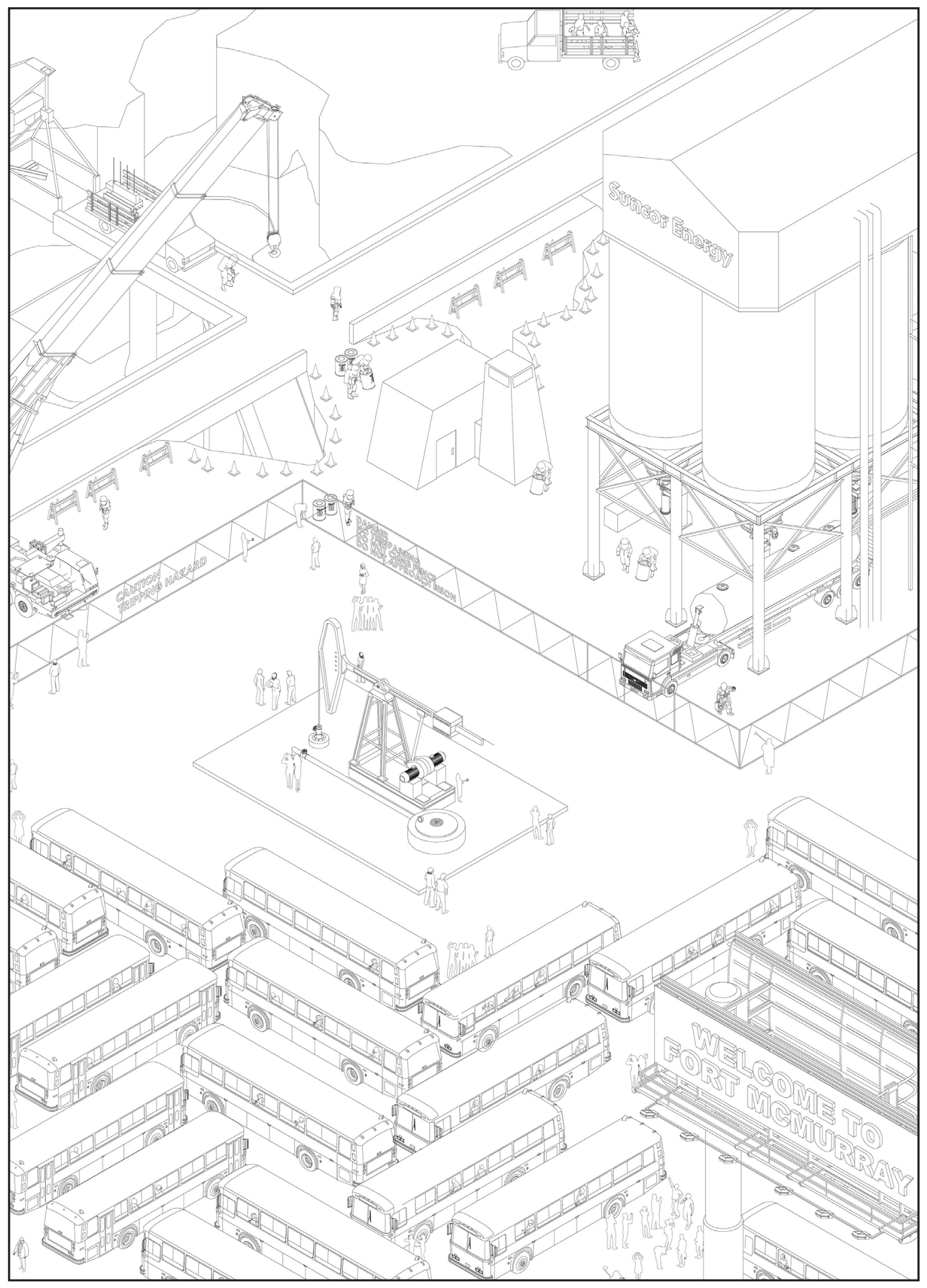




\section{TOXIC TOURISM}

In the summer of 2058, the Fort McMurray Tourism Center added the Oil Sands Bus Tour to the list of tourist itineraries. Since day one when I started driving my new shiny battery-charged Tesla bus, I knew someone had finally harnessed the potential of pollution as tourism. I am a 33 year old single man and I make way too much money, a lot more than I can ever spend here in the Great White North. I often take the weekends off from work and head down to Vegas with some of the other Tesla drivers - but even that is getting dull.

I spend most of my time ferrying tourists to and from the toxic sites. Don't get me wrong - I still do save some money to send back home to my family in Model Town, Lahore one of residential suburbs just outside the city, in Punjab, Pakistan. With the money I send them they probably have their own super-mall and mosque by now. They always complain that I don't visit more often. I do like to see my family, but let's be honest, even with a first class flight it takes more than 25 hours. Who would want to do that even twice a month?

The other day, a well cultured couple signed up for the Syncrude Ltd. tour. I didn't leave until the following morning. I wanted to take them both. Apparently the husband had too much fun at Carbon Boulevard the night before and was not feeling too well. There are times when some view these touristic destinations over romantically, particularly those experienced tourists. Such noble tourists, those are my favourite. I really admire these noble explorers who seek danger and are fantastic risk takers. You can tell those who are excited to explore new places and meet strangers. They are almost always the well-educated ones, having traveled to many places. 
I wonder sometimes if the tourists come here to accumulate experience so they can elevate their social status back in their elite circles. Or are they here to see the delirious madness and experience firsthand what it is like to be diluted in the sanitizers and breathe through plastic tubes? Oh, how they experience the world through a respiratory protection face mask!

Sometimes I wish Fort McMurray had more roads and highways, so I can take detours to see what is left of the forest. Since the big oil bust, the authorities - they are such muppets! - have sealed off the overburdened territories and the only road to the city is Highway 63. Not Highway 61!

Except for the benevolent and carefree individuals, most of the visitors on the toxic journey are surprised how benign the site is. If they have even a smattering of education they should know that toxic sites lack visual evidence. You cannot know it is poisonous until you remove your respiratory protection and your body reacts to the heavy particles in the air. The pain in the lungs is sublime as they struggle to catch their breath after 3 minutes of exposure. ${ }^{3}$

Last night, after my last shift, I was so frustrated by my hazmat suit I closed all the doors and windows and took the suit off. Sometimes I wish our hazmat suits were not so standardized, and we could have them tailored. We exist $24 / 7$ so why not have a perfect fit? I would personally pay whatever it would cost to get it fitted so I don't have to walk like a penguin when I cross the road. 
As I was enjoying the liberation from my suit, I had my head pressed against the side window of my bus; I was looking through the front window. I was parked on the top level of the parking lot. To my left I saw the forest and, as I turned my eyes to the right, all I could see were mines and abandoned refineries in a bare-naked ladies landscape. I was in awe for a while mixed with that horrific feeling of crash test dummies.

There was a problem with the scale of what I was seeing; the leftover of the previous generations are monuments of our generation, the gargantuan draglines and 400 ton trucks seemed so tiny, like a little 3D printed souvenir. This was more than a broken social scene. I could not stop thinking about bigness, weight and land. The biggest machinery in the world is now in front of my eyes; they are so tragically hip like ants in a sandbox loomed over by the titanic scars they have created. 


\section{CONTEXT}

The geographical limitation of The Athabasca River and its boreal context is the framework that leads to the development of Toxic landscape and Toxic Tourism, a project that anticipates a more radical planning tool for Alberta. This will help us critically assesses current lucrative oil sand operations, with their operative focus on Capital. The initial catalyst for toxic landscapes is an understanding Alberta as two radically opposed urban conditions: a sea of single family homes are being replaced by workers' settlement camps and a gargantuan industrial site that is perpetually growing larger and deeper.

- Toxic Tourism offers an alternative to the archaic business-as-usual model for the tar sands/oil sands and intends to change this country called Canada forever.

- The old system was intended to enrich a few powerful companies, dull the economy, erase the world's third-largest watershed, industrialize nearly half of Alberta's land, guzzle the last drop of supplies, and grind down Canadian independence. Here Toxic Landscapes are metaphors for our never-modern existence.

- Toxic Tourism aims to search for a dialogue between tourist attraction and involuntary revulsion, fantasy and trepidation.

- Toxic visitors are allured by their individual desires and serendipity for fantasy; though they are conscious that the land is grieving from human's capitalist triumph.

- Toxic Tourism magnifies the visitors' concern for land and traps him or her within a tense contradiction where each toxic sight is opening onto a reflecting pool. Can they believe that they are experiencing the last square mile of what is left from Canada's boreal forests?

- More than a million tons of forest displaced on a daily basis. The Toxic Tour intends to showcase the 200 square mile of toxic-ponds, emitted carcinogenic emissions and the dried up Athabasca River. The Boreal forest of Canada is the largest vegetation region of Canada, covering about 55\% of the country's land mass. These expanses of virgin timber land the area of New York State. ${ }^{4}$ The Boreal forests extend from northern British Columbia in the west to Newfoundland and Labrador in the east. ${ }^{5}$ The trail of Boreal forest passing through Alberta has been undisturbed for 10,000 years until 1719, when a Cree named Wa-Pa-Su took a sample of oil sands to Henry Kelsey for trade at the Hudson's Bay Company. ${ }^{6}$ Peter Ponds, an American explorer, traveled to the north and explored Athabasca's springs of bitumen in 1778, which marked the dawn of a petro-state for Canada. 


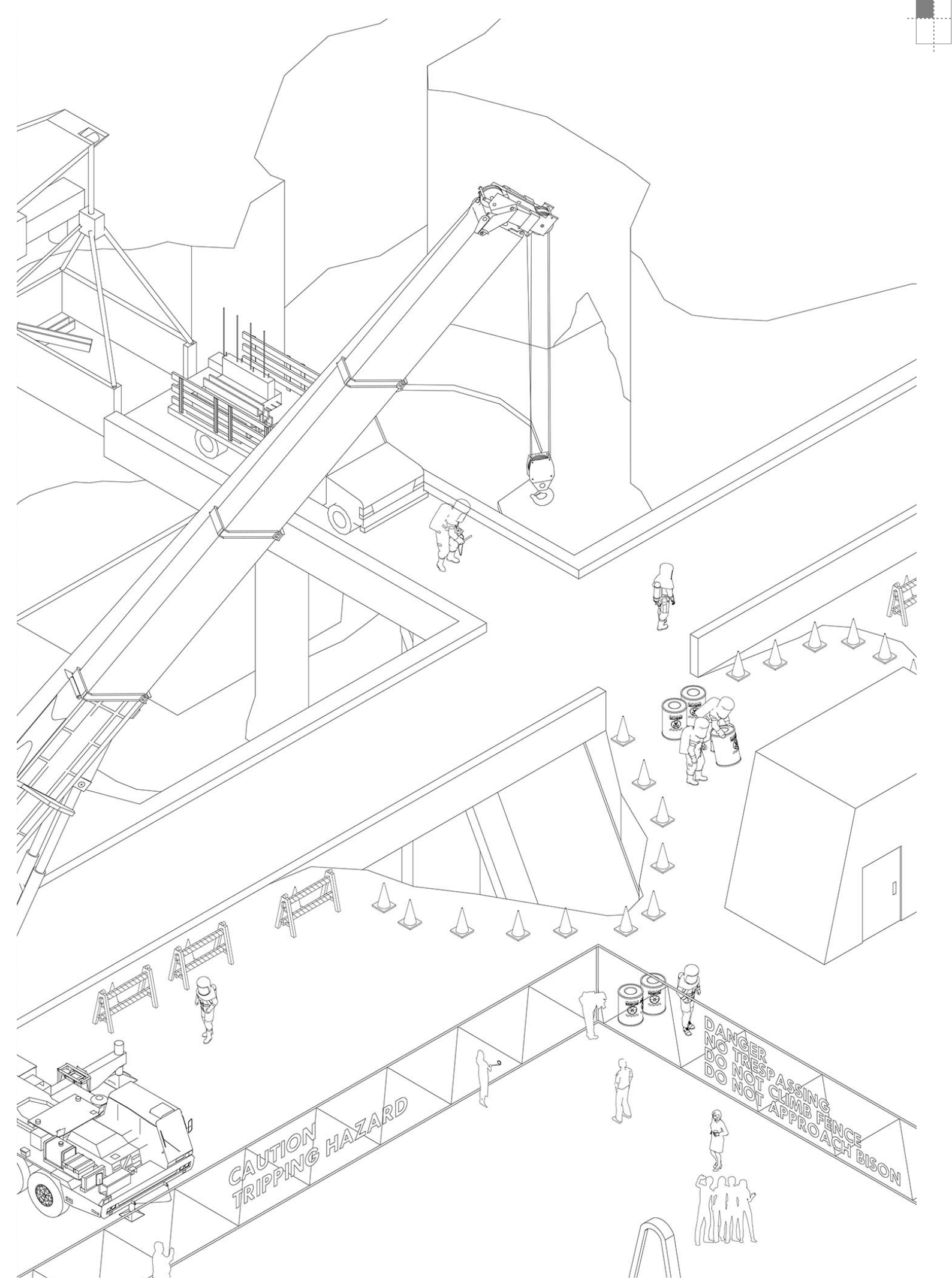




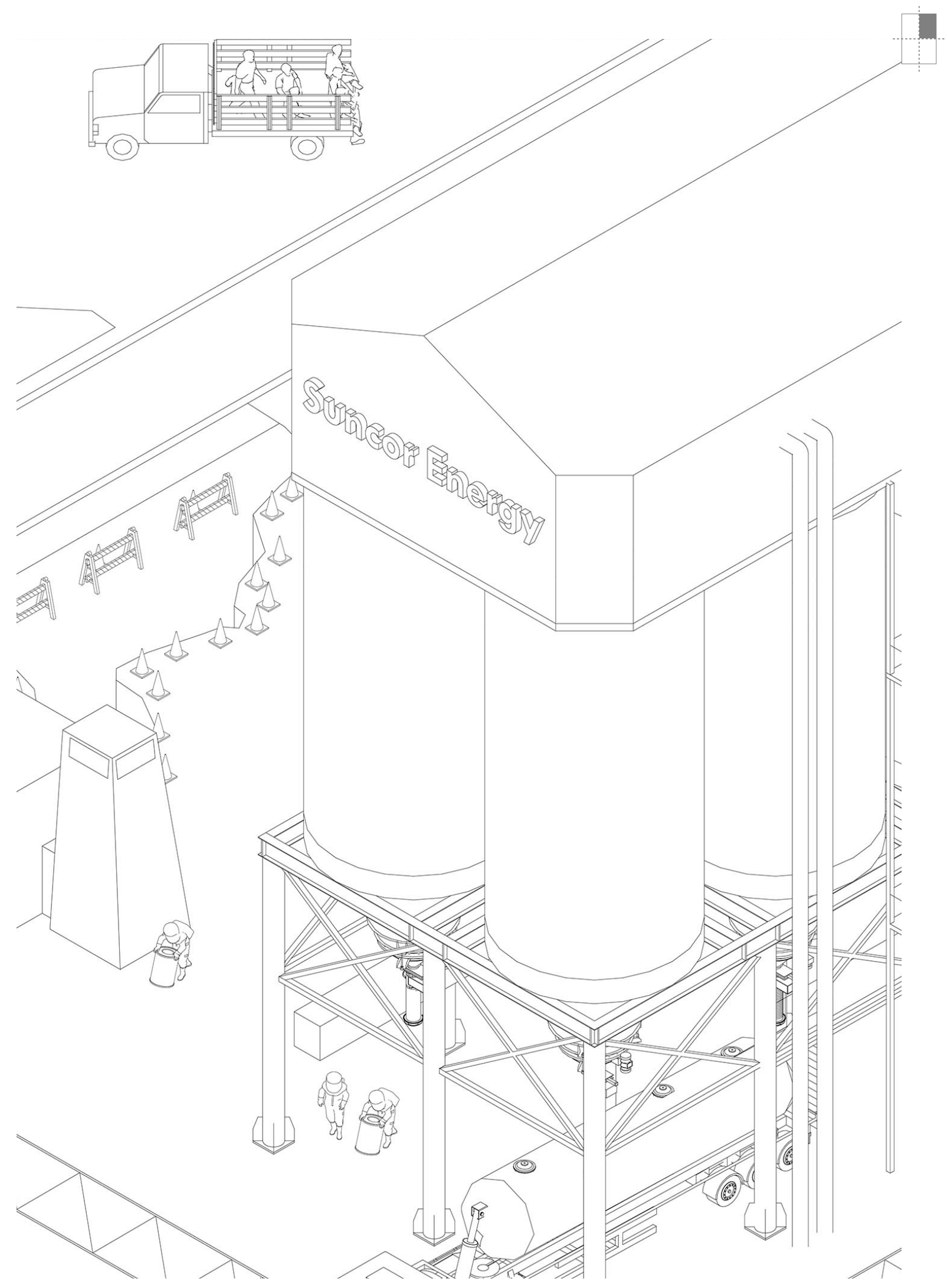




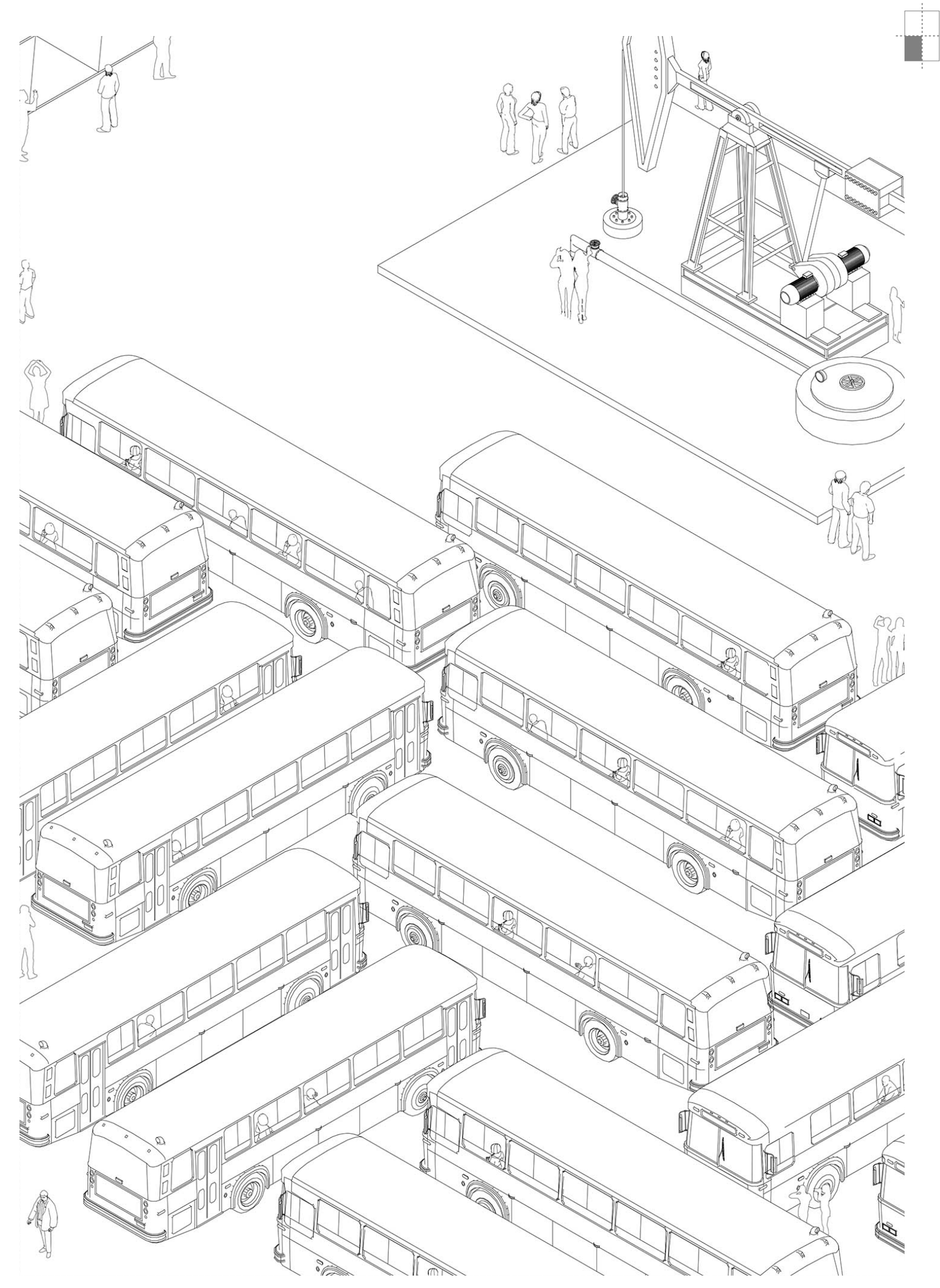




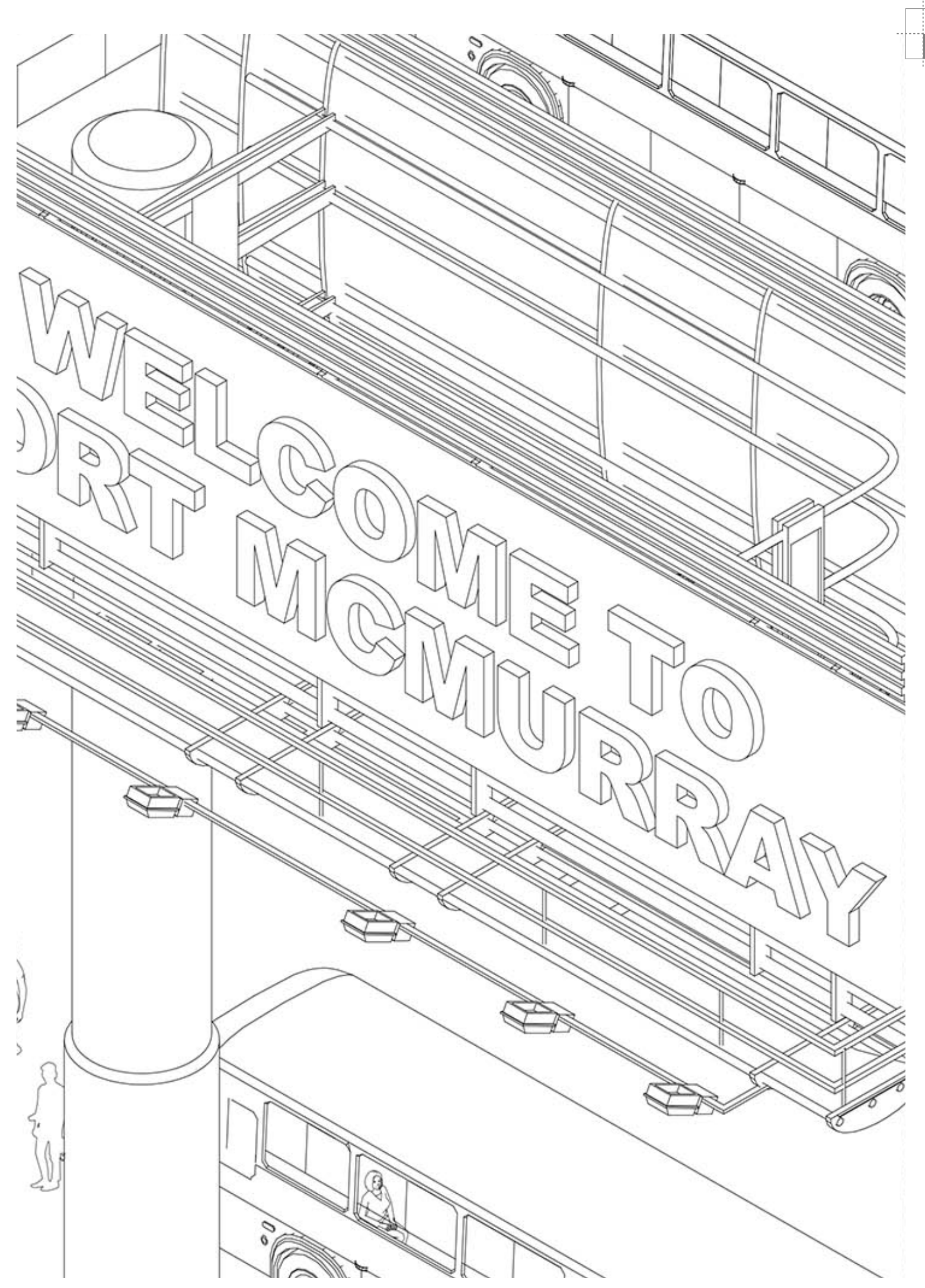




\section{NOTES}

Today, Canada is reaching the point where the risk of concentrating on one industry is proving more than problematic.? Though some oil sand critics such as New Democrat Rachel Notley, Amin Asadollahi of The Pembina Institute, a clean energy think-tank and Greenpeace spokesman Mike Hudema, ${ }^{8}$ all question the damages unleashed upon the environment, their fear of oil sand monsters scooping, hauling, and extracting oil sand through multi-stage serpentine systems is understandable. ${ }^{9}$ According to the Canadian Association of Petroleum Producers there has been a 15 percent rise in greenhouse gas emissions produced by Canadian oil and natural gas production since 2009.10 Perhaps that is what forced the recent Conservative government (Stephen Harper) on Dec 12, 2011 to pull out of the Kyoto Accord on Climate Change.11 The potential economic damage is less publicized since the United States is the major consumer of the Canadian oil sand production with little concern for the unbalanced economy of Canada. ${ }^{12}$

Since 2007 for every natural resource job opportunity, 15 manufacturing jobs have been exported.13 The frustration in the soaring crude oil price seems to be nothing compared to the pump and dump scheme of the American oil corporations; less than half the oil sands output is upgraded in Alberta, the rest mostly refined in Port Arthur, Texas. As Eric Reguly, an award-wining Canadian journalist stated; "exporting raw oil is exporting jobs and talent."14 The oil sands mining consumption of energy is almost as much as its production according to a 2013 report by Rachel Nuwer from Inside Climate News. "The average 'Energy Returned on Investment', or EROI, for conventional oil is roughly 25:1. In other words, 25 units of oil-based energy are obtained for every one unit of other energy that is invested to extract it",15 oil sand surface mining had an EROI of only about 5:1, and the oil sand extracted from deeper layers of earth had even less EORI, with a maximum ratio of about 2.9:1 which is almost one unit of natural gas for 3 units of oil based energy. Oil sand companies have to use a lot of natural gas and fresh water to upgrade the heavy, sticky, gooey tar-like oil into a fluid required for further processing. ${ }^{16}$

Once upon a time, very few noticed the Tar Sands Sand, but now - the biggest in the world - it is impossible to ignore. ${ }^{17}$ 'The Great Black North' is how journalist and filmmaker Andrew Blackwell of the New York Times, refers to Alberta, Canada: "since the Canadians had hit the grim bull's eye in the world's largest energy project they have metamorphosed to the Middle East of the Great White North, established a gargantuan institute-mining spectacle of mega trucks, mega electric shovels, lakes of toxic waste, and giant sulfur pyramids growing out three dimensionally just for kicks." ${ }^{18}$ 
It is astonishing how much political capital the federal government is investing on oil sands, given the undeniable risk of having one dominant economy. According to the United Nations Population Fund (UNFPA) Canada's population will reach 41 million, as Reguly mentioned "in 50 years, maybe 25 years, Canadians may come to regret the rapid pace of oil sands development."19

As lucrative as the fees and land lease deals are, the end of the oil boom is inevitable. Concentrating on one industry has always led to a rapid demographic shift; the fall of manufacturing jobs has also resulted in the end of state control over corporate activities. Oil sand industries create; leave colossal land scars which are relentlessly reshaping the topography of Northern Alberta. Little energy is spent to prevent the bowdlerization of boreal forests. 


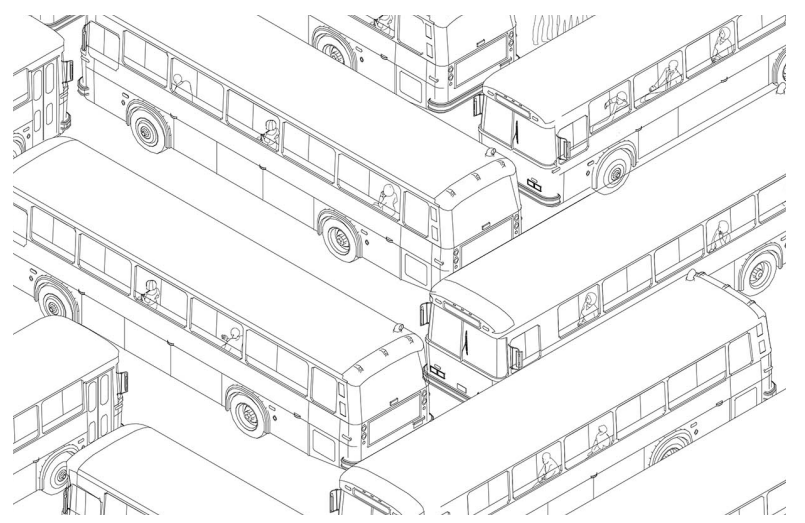




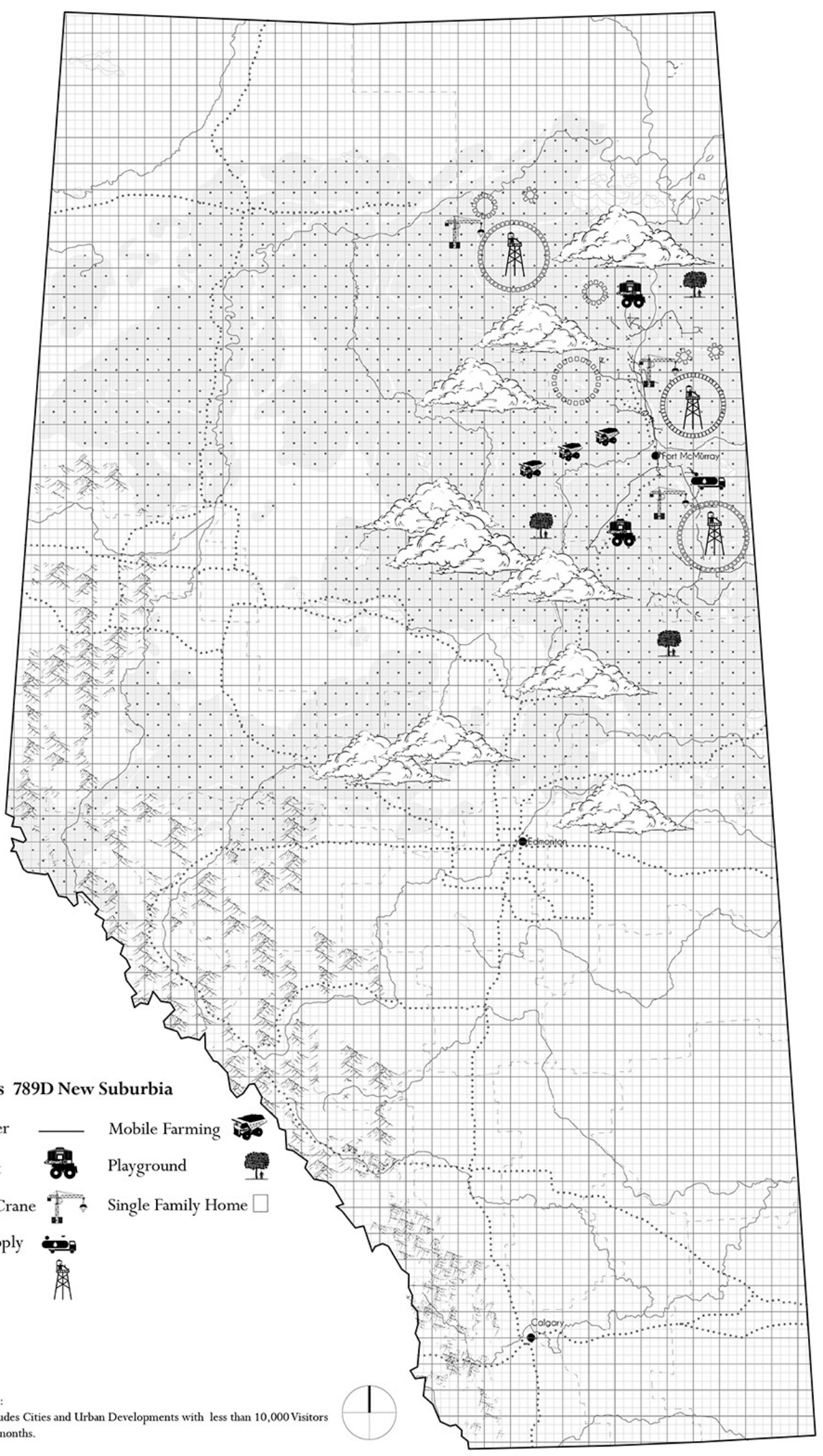




\section{D SUBURBIA \\ PART 2 \\ "Paradise is a state of being, more than \\ just the name of a suburb or a home." 20 \\ -Raquel Cepeda}

Suburbia is a mobile ground on the quest to establish a new region, with ephemeral edifice. It is a territory of roads and monster trucks escaping the urban zone of the Petropolis. Parents have made these regions into new 'monster pastoral' countryside on wheels.

Keywords

Consumerism

Mega Trucks

Mobile Farming
Vancouverism

Resilience Housing

Walk out With a View

Crude Oil Aroma

Truck Mart

CAT Golf 


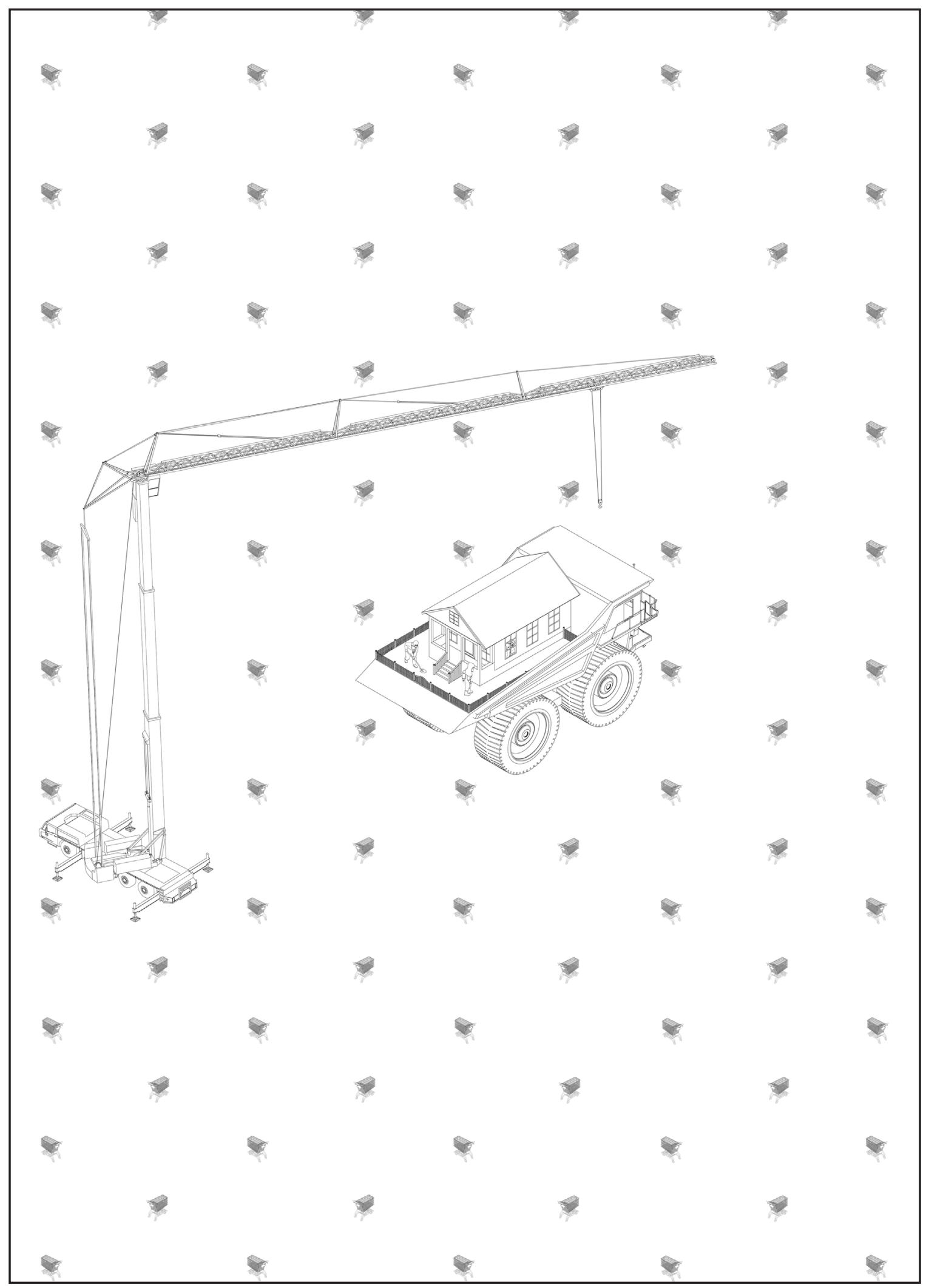




\section{D SUBURBIA}

789D Suburbia is a follow up of the Toxic landscapes series; a response to the PostAlberta housing condition. A sea of single family houses is transformed to workers' camps. 789D Suburbia is a fairy tale set after Alberta's oil boom in the not so distant future.

The primary purpose of 789D Suburbia is to highlight where the consumer class is destined to go, and how Alberta is preparing itself to reduce the energy and resource rigorous lifestyle that is currently beloved. 789D Suburbia examines the energy intensity of current consumer culture in Alberta. It aims to create a sustainable housing solution for a future without extensive dependency on oil. 789D Suburbia reflects on the current energy supply situation and considers the fate of consumers in the context of an imminent decline in oil supplies. 789D is an intelligent mining truck that battles hostile conditions in Canada's highest production Oil Sand surface mines. $789 \mathrm{D}$ is a colossal mining machine that is 8 meters tall, which makes it the largest on the planet. ${ }^{21}$

$789 \mathrm{D}$ is a mobile two storey house, hauling 300,000 tons of sand a day to uncover a fortune in black oil. This $\$ 5.5$ million beast achieves the impossible thanks to a 2,100 hp engine with a fuel tank of $3785 \mathrm{~L}$ at a top speeds of $57.2 \mathrm{~km} / \mathrm{h}$ that could power a freight train, 6 super grip tires at 3.569m in diameter and $4100 \mathrm{Kg}$ each and a survival system that is built for the toughest climates. ${ }^{22}$

Given the evolution of tire design, 789D tires mimic Mother Nature, modeled from the unbeatable grip of cat's paws; the weight of the truck compresses the rubber treads on the tires displaces rock and dirt that is stuck in between the grooves. For $\$ 70,000$ each, the tires clean themselves. 
Built from 50,000 components, the $789 \mathrm{D}$ is the pinnacle of truck design. At full capacity, the 3 megawatt electric generators can provide power to a town with a population of 10,000. The back bed can haul up to 4000 tons, the weight of a jumbo jet. This mega truck was built for one reason only; for hauling more earth than any other machines. 789D refuels at least twice a day; any excess rise in the core temperature of the truck can lead to a disaster. Thanks to the engineering innovation and architectural phenomenon of vancouverism, 789D is integrated with a smart urban planning strategy to give birth to 789D Suburbia.

789D Suburbia aims to downscale for environmental and social fairness reasons, but the main focus of the new suburbia will be on the implication of downscaling, and how it may impose a post-individualism for Alberta. While this fictitiously enforced downscaling of lifestyle will be an unpleasant surprise for Albertans, the people will actually benefit from voluntarily embracing a modest lifestyle of reduced social interaction and resource consumption.

While energy supply issues pose unparalleled obstacles for Albertans, 789D Suburbia argues that with prudent planning the mandatory transition away from energyintensive consumerism would lead Albertans down a more enjoyable and sustainable path, such that Albertans will voluntarily choose this path. 
?

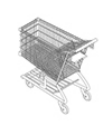

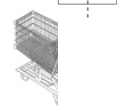

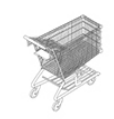

r

?

장

s
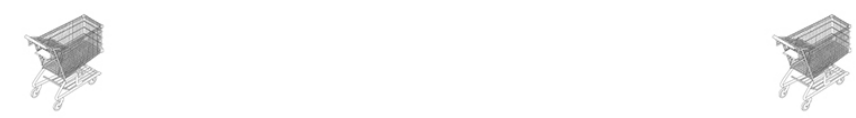

?

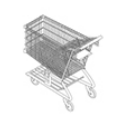

$\$$
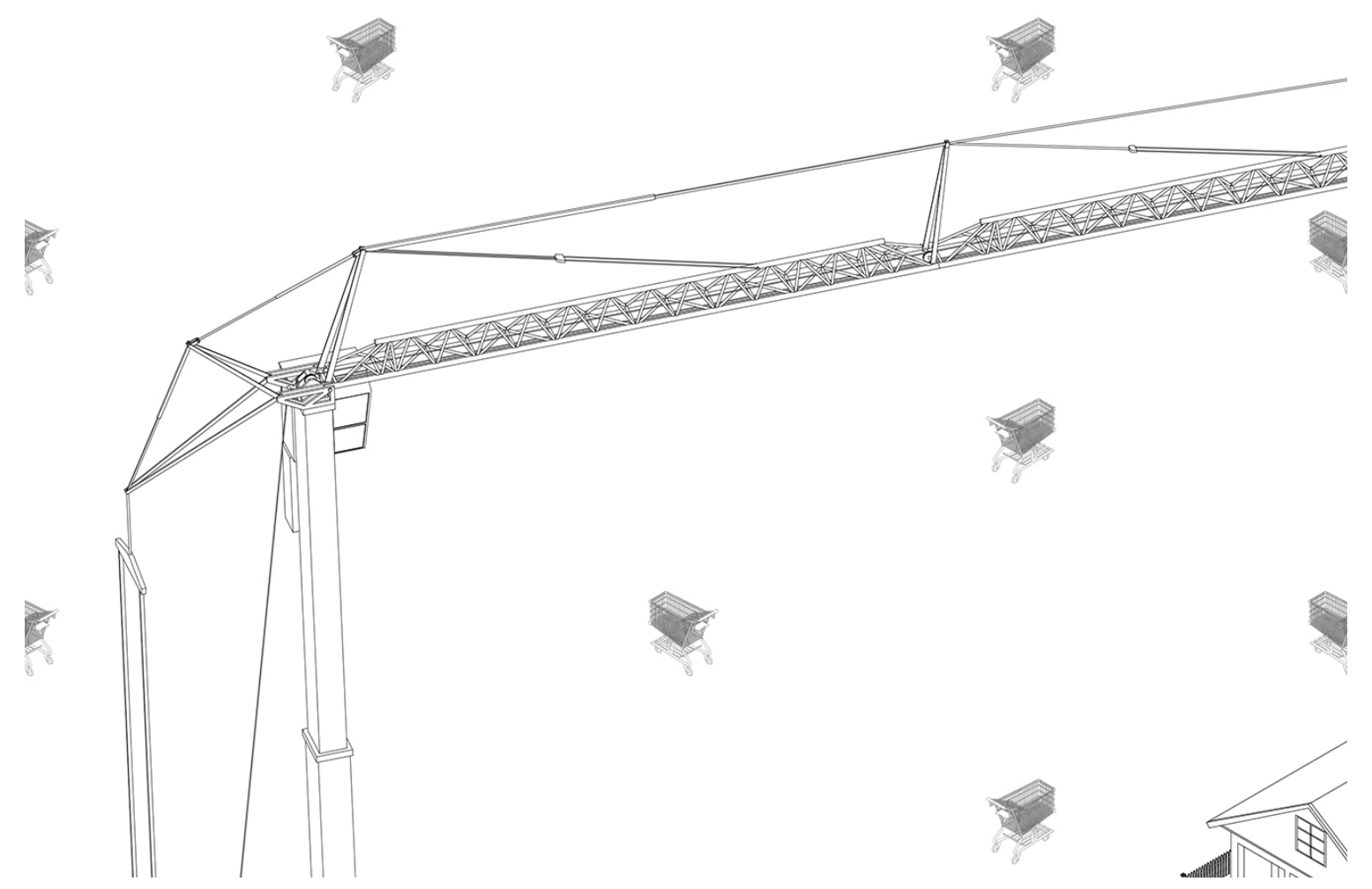


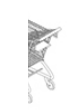

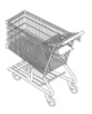

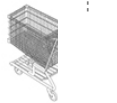

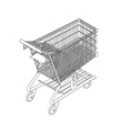

?

8

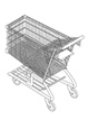

3

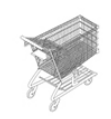

)

8

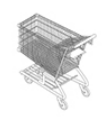

S
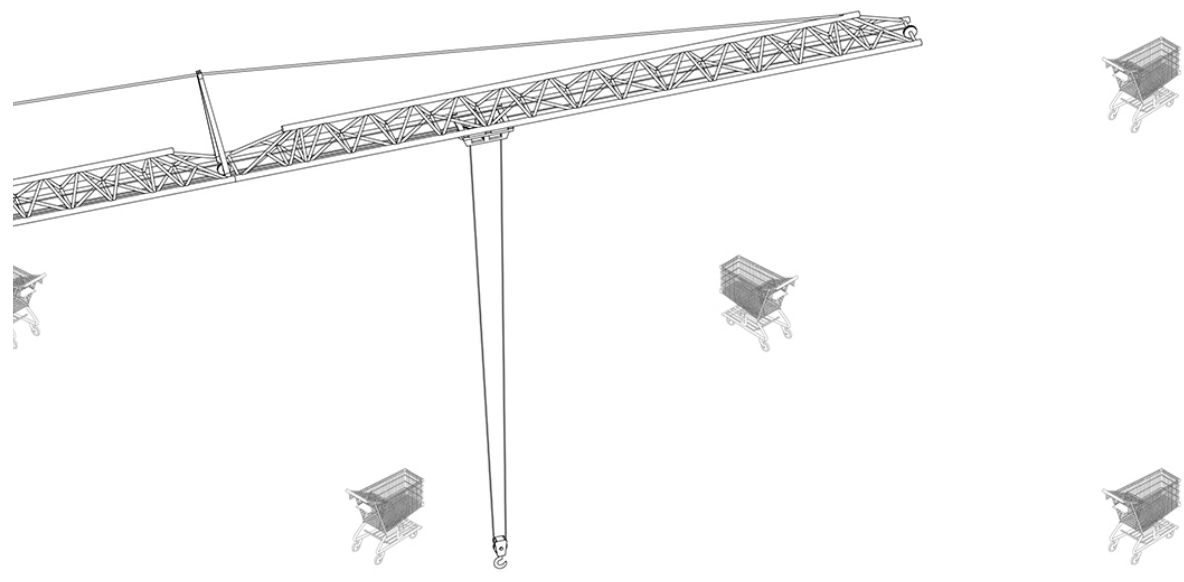

공

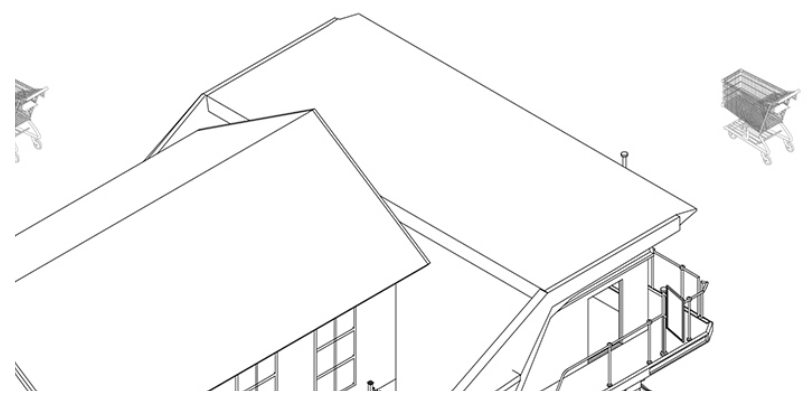

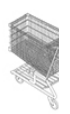



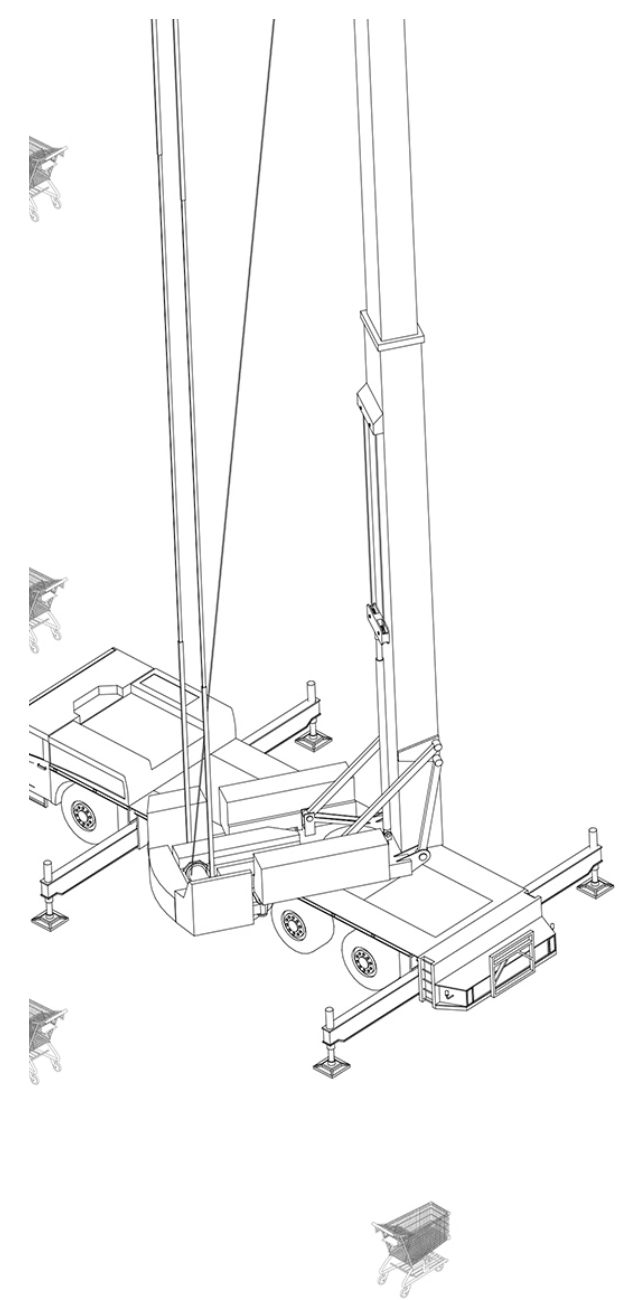

है

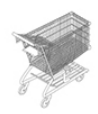

है
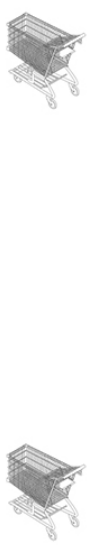

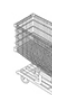
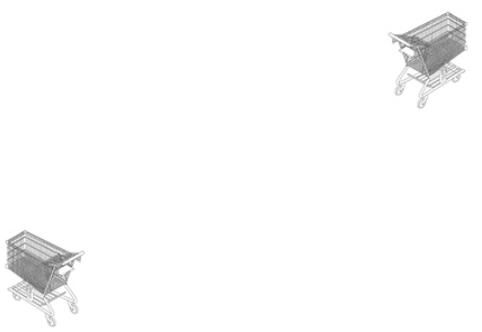

S

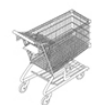

\&

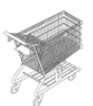

3

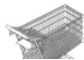



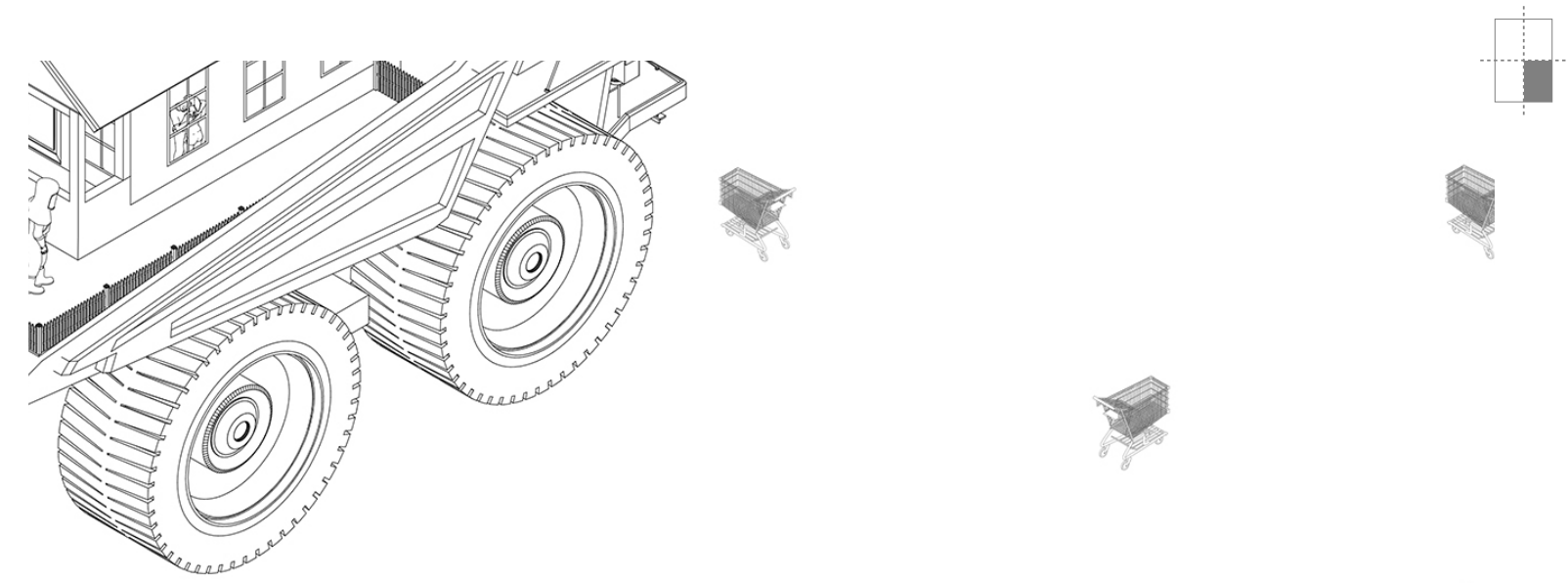

의

의

?
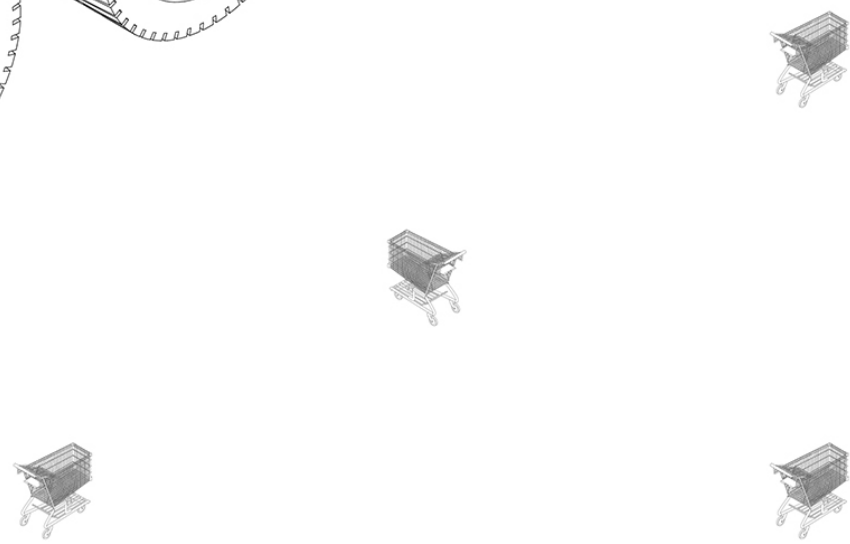

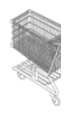

है
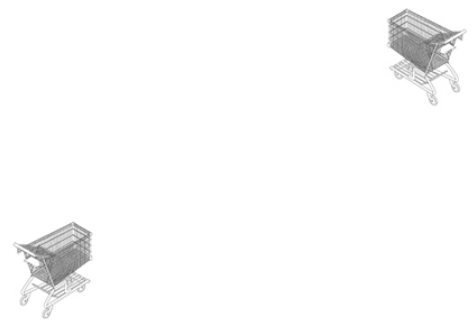

,

$\sqrt{2}$
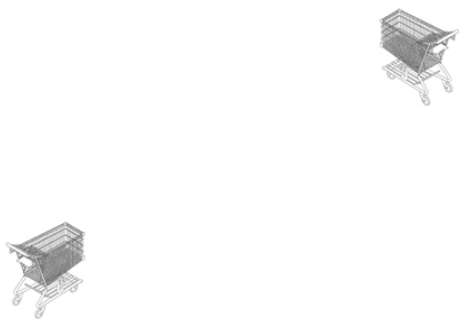

है

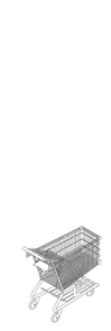

S?

t
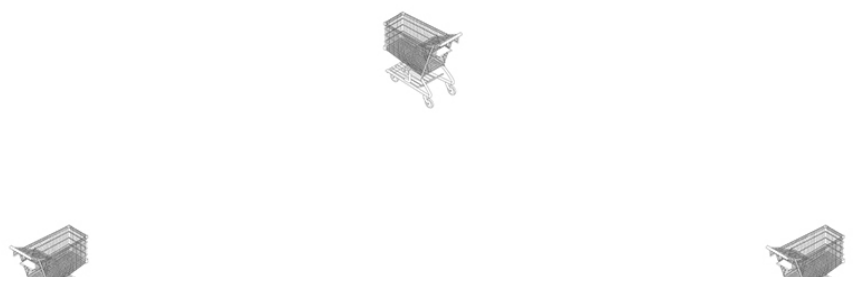


\section{NOTES}

The Petroleum industry has drastically reduced agricultural populations, and rapid mechanization that has shifted the labor force to the service sector. ${ }^{23}$ Globalizing trade and culture, imposing regulations on the world economy inevitably gave birth to mega cities; conurbations that were once a distant dream became reality. The rise of consumer societies and the transformation of western ideals of 'personal

\section{Conventional Oil: Discoveries vs. Production}

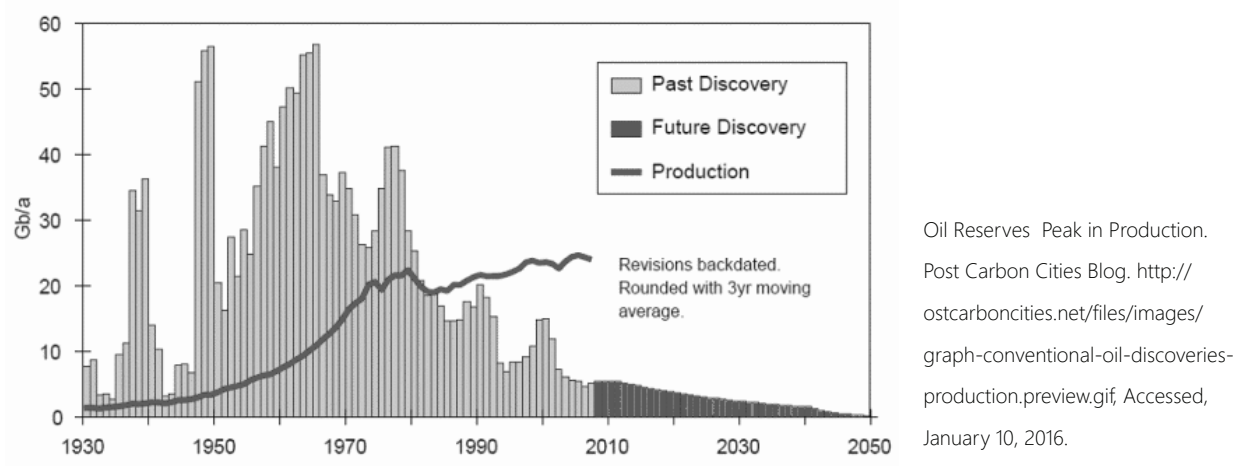

freedom' and democracy into a powerfully appealing (as well as fanatically resented) global force have only been conceivable due to the lavish supply of cheap oil. ${ }^{24}$ Despite the fact that the demand for oil is expected to grow significantly, there are growing concerns that the conventional oil reserves have reached their peak in production.

Suncor Millenium Mine, Alberta, Canada, Louis Helbig. Blog.http://www. beautifuldestruction.ca/project/open-pitbitumen-mine/ Accessed, January 10, 2016

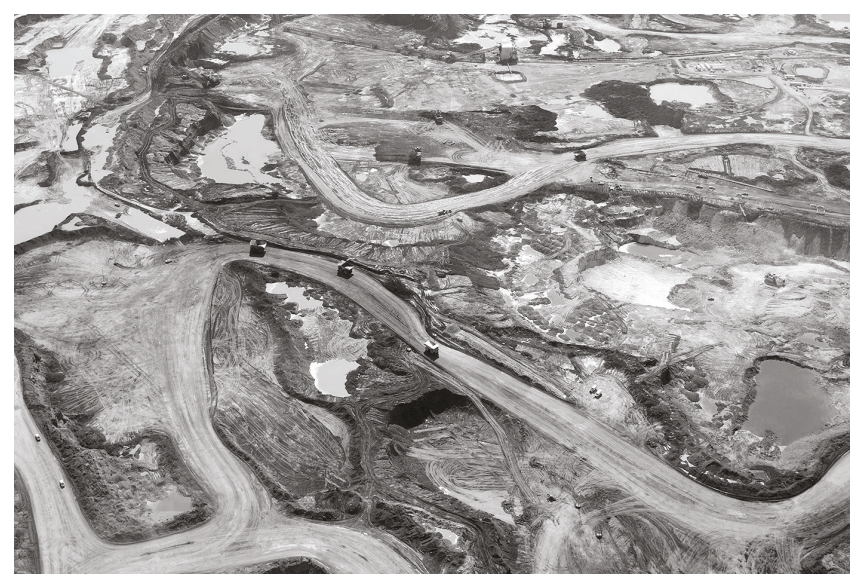


Nevertheless, consumerism depends on the nonstop supply of fossil fuel. As Alex Samuel, (Office for Environmental Programs at University of Melbourne, Australia) mentioned in his 2012 paper on Peak oil, "Oil is the ultimate foundation of industrial economies" and it will soon "face a situation where economic and geopolitical competition escalates over access to increasingly scarce oil supplies". Thus, all commodities rise in value, and this will have pervasive consequences on the globalised economy and the consumer societies that are dependent on the global market. ${ }^{25}$

Additionally, Western civilization has played a huge role in making irreversible environmental mistakes, such as:

- Colonialism

- $\quad$ Free trade policy

- Investing too much Capital in none renewable resources

- Deforestation

Fort McMurray, Alberta is a perfect example of brutal recklessness towards the environment. The consumer's lifestyle is energy intensive, therefore requires perpetual production of oil from the tar sands. As the demand for pseudo-objects rises, the size and number of the oil sand mining companies rise too. Consumerism is inversely connected to the deforestation of Alberta's boreal forest and the devastating shortage of water that eventually leads to Athabasca River drought, (according to Green Peace Canada). ${ }^{26}$ 
1

V

18

당

5 


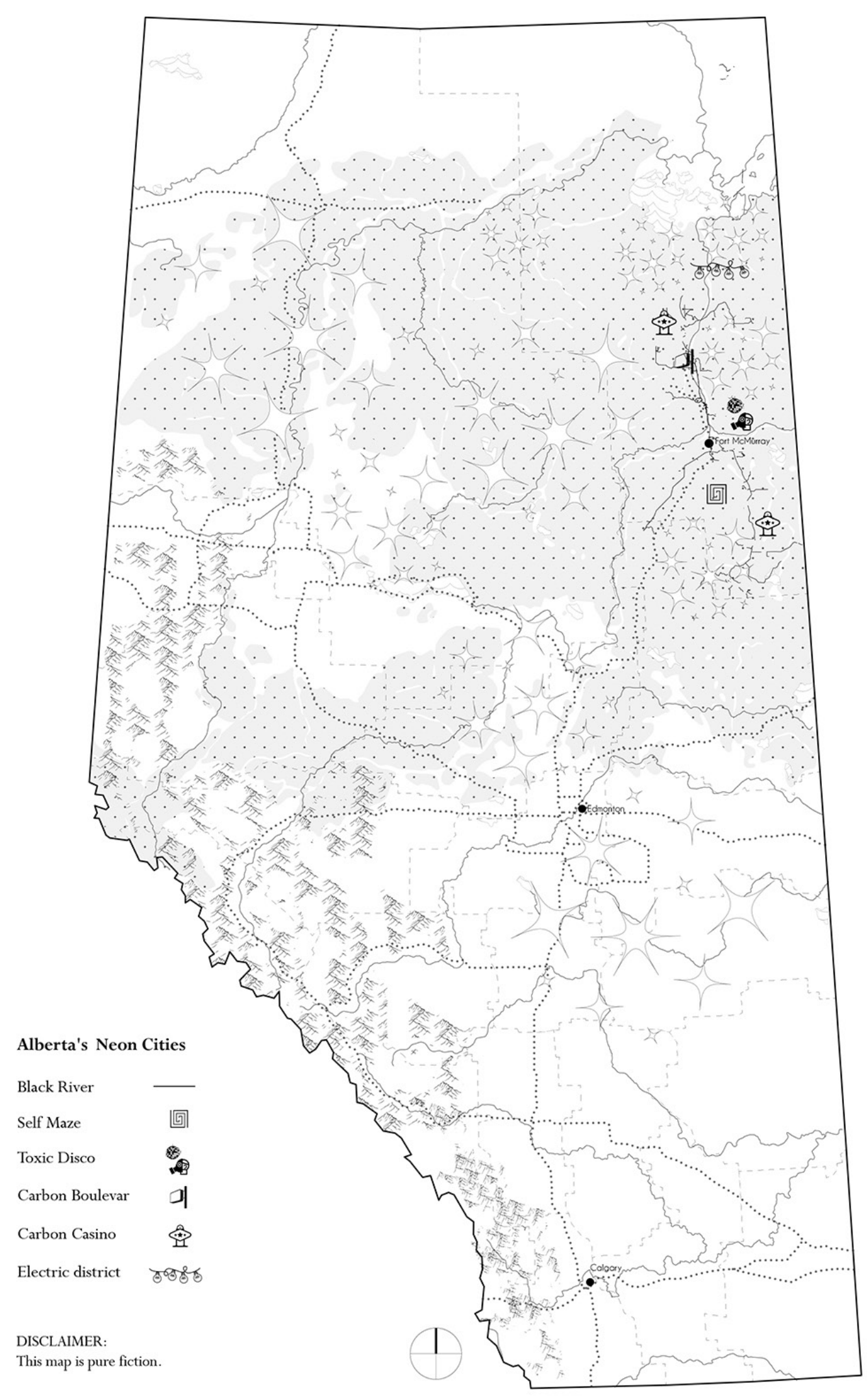




\section{CARBON LUST / THE NEON CITY PART 3}

"A map of the world that does not cover

Dystopia is not worth a glimpse." 27

-Os. Will

The Neon City is a self-reflecting territory made of an intricate maze, a network of oil and gas refineries, and a new land where illegal consumption is authorized. This senseless territory offers a hidden feast of drugs, sex and fantasy, within an infinite network of pipes, storage tanks, and spiral stairs. Here, visitors experience the disconnected autonomous moment of time being at the mercy of Great White North. In this New Alberta, the economy of survival is found in prostitution. Carbon lust is a platform for a Dionysian bacchanalia of surplus.

Keywords

\begin{tabular}{llcrlrl} 
City & Lust & \multicolumn{2}{c}{ Sex and Drugs } & Labyrinth & Theory of Leisure & Carbon \\
Boulevard & Vegas Strip & Carbon Casino & Electric district & Alberta \\
after Rain & Carbon Carnival & Hazmat Suit & CATHouse & Happy Urbanism \\
Reclaimed Lands & & Abandoned Refineries
\end{tabular}




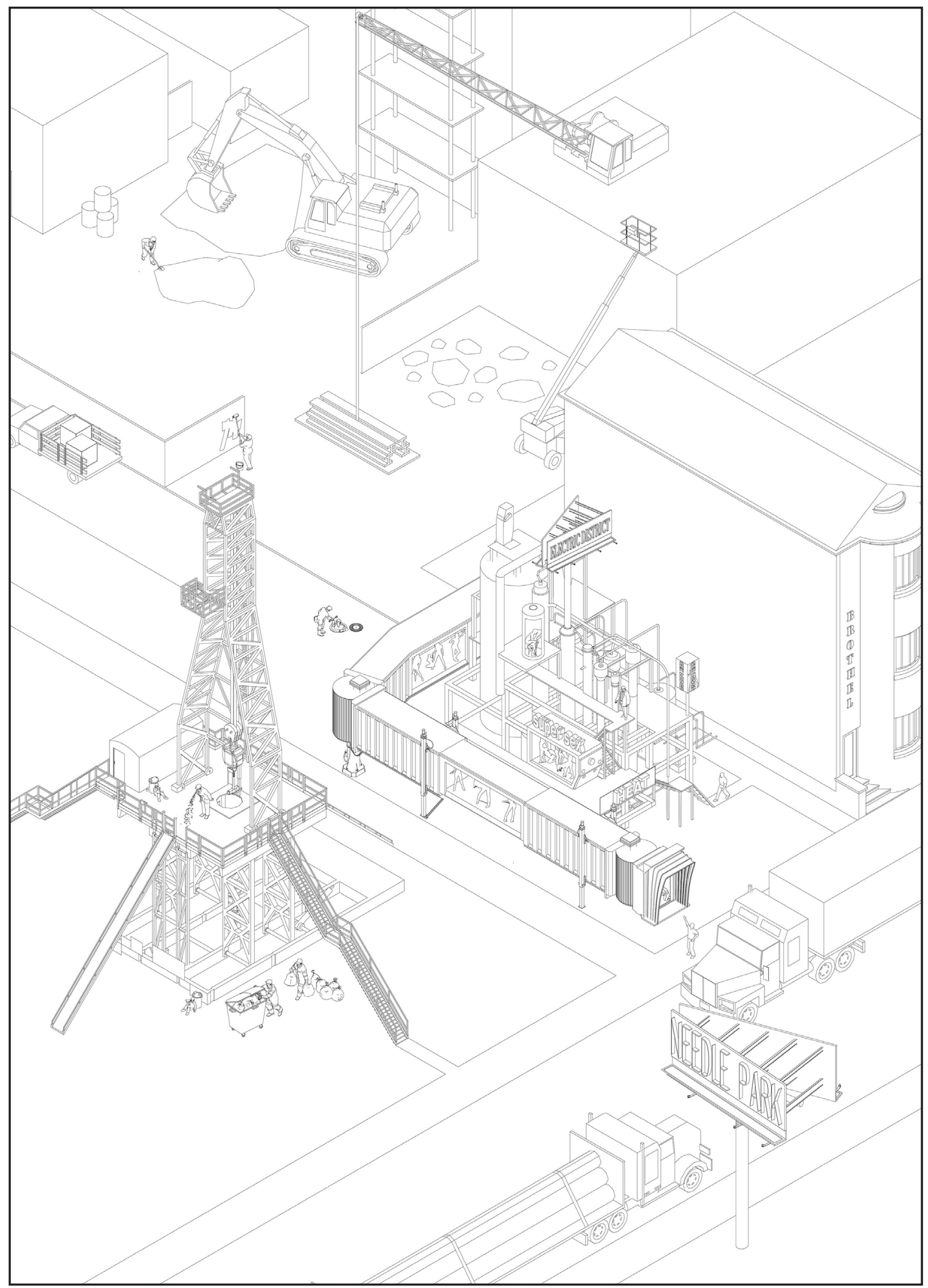




\section{CARBON LUST / THE NEON CITY}

Neon City is the third scenario of the Toxic landscape series, a peculiar fantasy built as a labyrinth on Fort McMurray's existing oil sand refineries. Ideally for an Alberta after the toxic rain, Neon City is built to host Carbon Carnival Casino offering radical night life and strong libido for the post-oil inhabitants.

In a Post-Petropolis scenario, the consumer society pushes towards a world of impermanency and rapid transformation of large scale edifices that were once meant to last a lifetime, now rundown, dismantled, transported, and adapted to momentary needs. Temporary structures are an impermanent way of life. They are symbols of a new ephemeral society, a society on the rise. Technological progress has helped to create an Eden out of Carbon Boulevards, devastated lands and unoccupied refineries. This is an idealized modern community bringing light, air and electric eroticism to the inhabitants of the doomed dark toxic lands.

As in films, cities of the future come with a cautionary tale about what might happen if we don't change our consumer lifestyle. In The Neon city there are no warnings, only illusory billboards to reinforce the post-individualism ideals for all.

The Neon City's architecture is built on the very machinery that was once hauling its ground piece by piece, rooted in the abandoned mining sites and faded dreams of the ideal production, Alberta aimed to achieve. It clings to the rustic pipes and heavy steel structure of the world's largest crude oil refinery. The Neon City is a Utopian idea that tells a story that transcends time of the future that may presumably help Albertans transcend their individual constraints. 
Finally, The Neon City is the servant of the CAT house, and one day will be fully immersed in it. Therefore, there will be no authority or any form of government in The Neon City but workers, journeymen, and hedonists each inhabiting their own labyrinth and calling it 'home'.28 


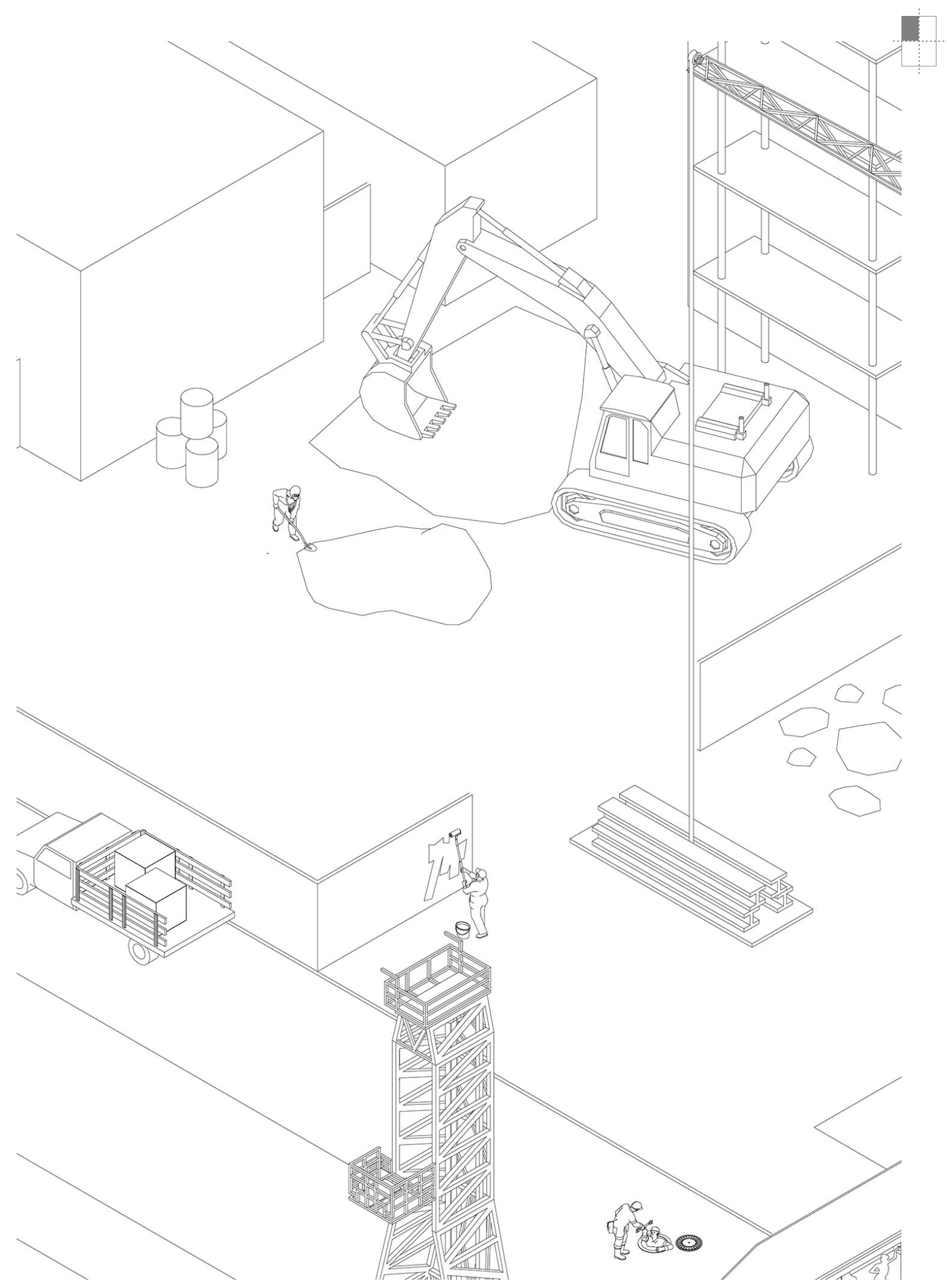




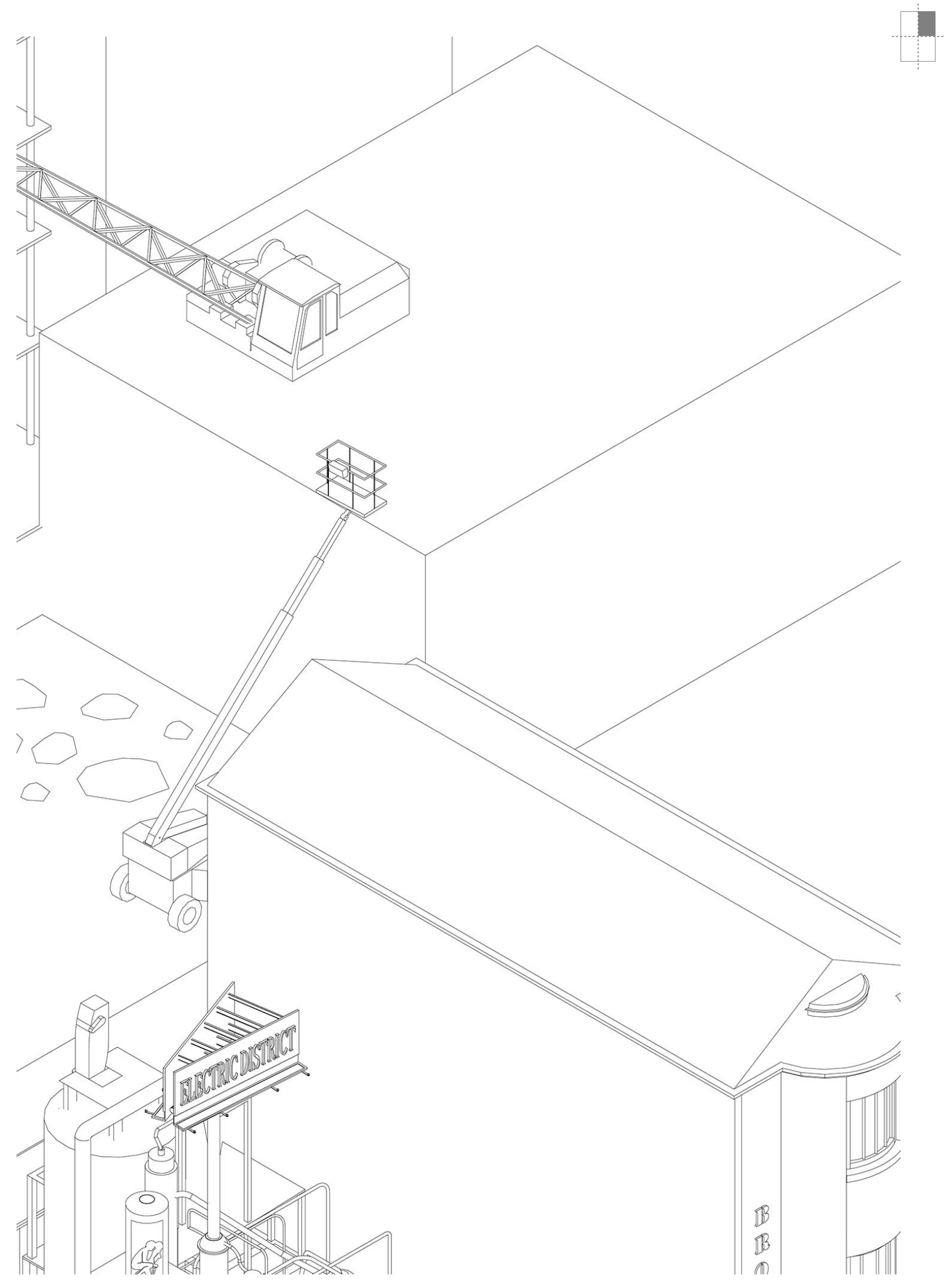




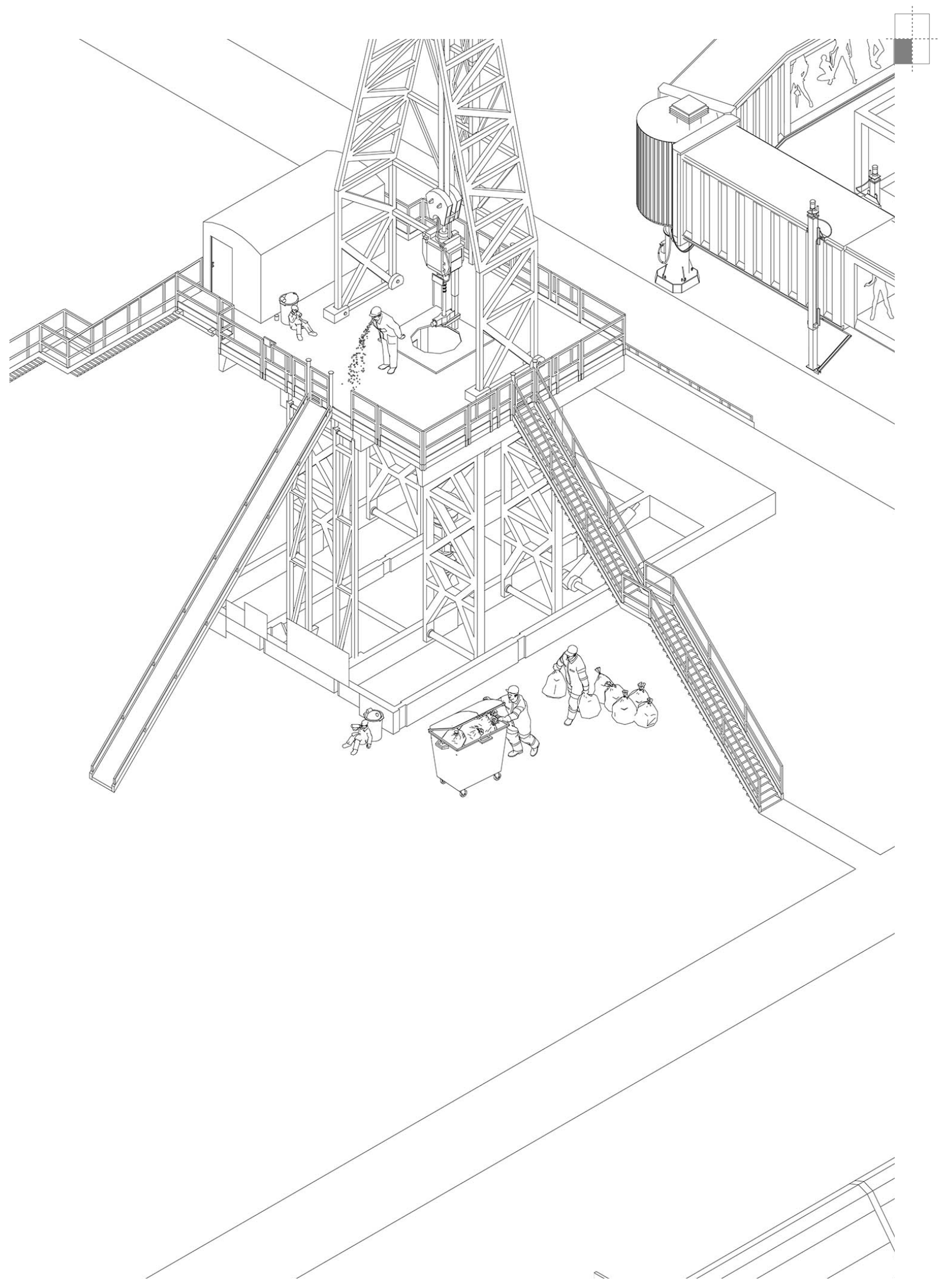




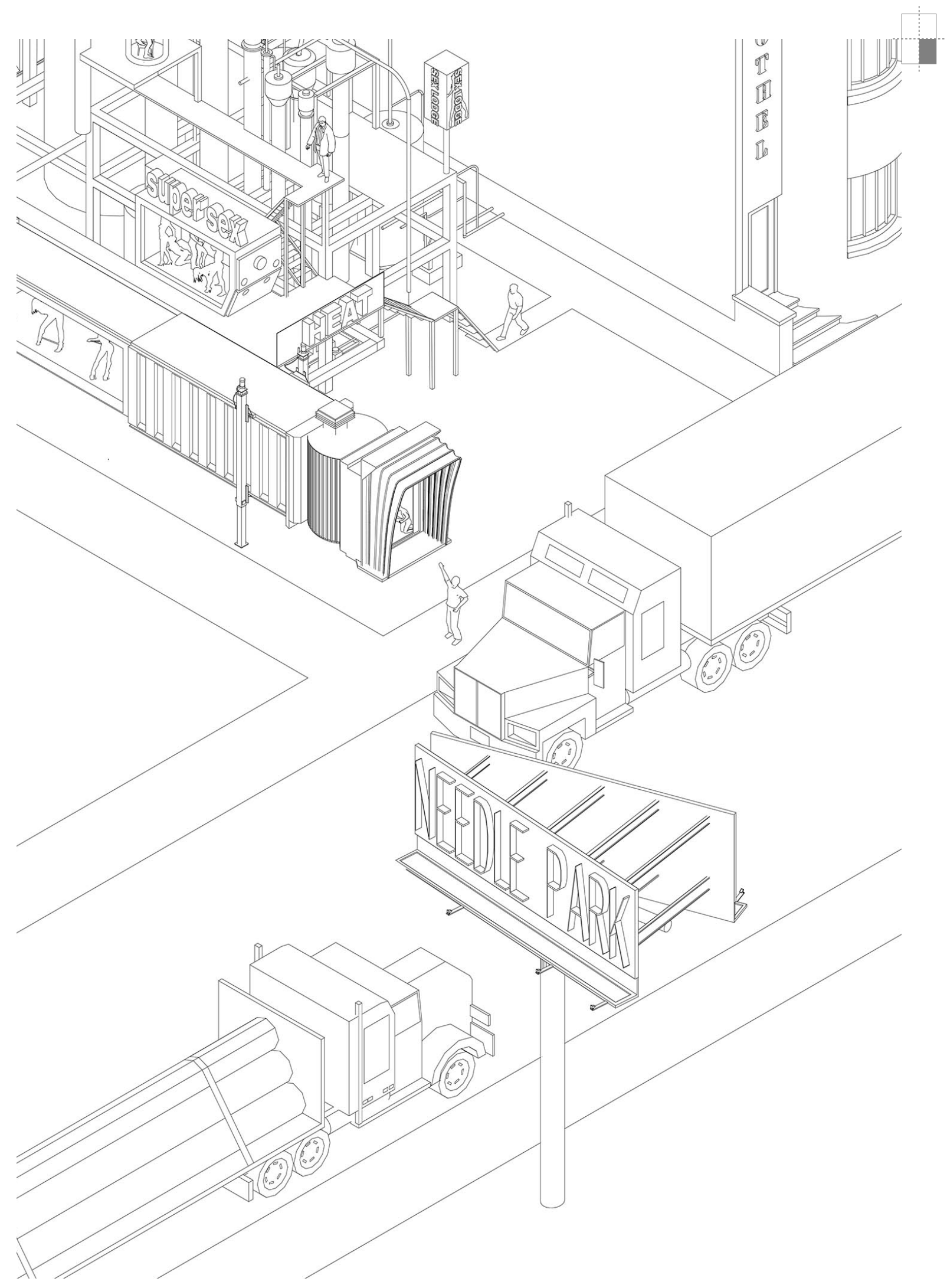




\section{NOTES}

Unlike idealized utopian dreams, The Neon City does not require a clean slate. The Neon City is a testament for collective aspiration of Albertans and offers the public a form for its perpetual development. This new happy urbanism expresses the ideal that Albertans wish to portray.

According to architectural historian Lara Schrijver, neuroscience is becoming increasingly sophisticated, revealing our unconscious responses to hidden hints. Social design is becoming increasingly strong, taming us toward respectable behaviour. Lara Schrijver argues in the catalogue to the exhibition COMING SOON that, "perhaps the realization of utopia is not an internal but an external matter; perhaps space indeed is the final frontier."29 The universe as we know it is paired with utopian promises, from landing on the moon to extra-terrestrial interactions, an ultimate transgression towards a new form of survival. ${ }^{30}$

We may never step into space time, yet in cinema current imperfections are annihilated via "aliens, asteroids or robots". ${ }^{31}$ When the antagonist is completely abolished, what remains is not just ruins but hope, the promise of a new future.

The Day after Tomorrow, 2004. Screen Shot. http:// www.movpins.com/dHQwMzE5MjYy/the-dayafter-tomorrow-(2004)/still-3181877248, Accessed

November 11, 2015

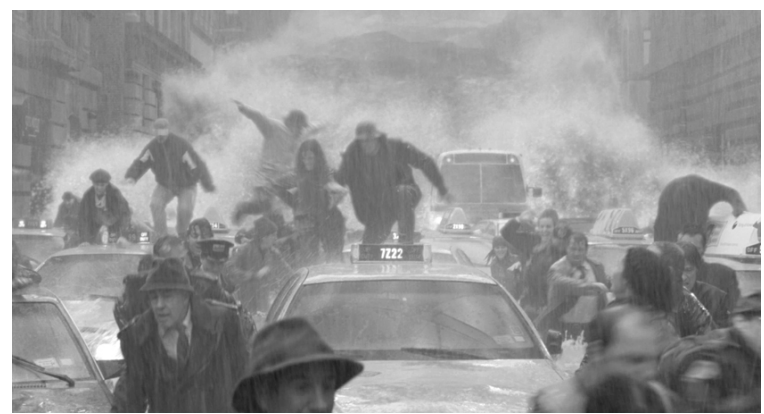

If we put aside the typical utopian scenario in cinema ${ }^{32}$ and assert that utopia does not require progression or destruction to flourish what would a Post-Petropolis City look like? Recent technological development has helped create a 'heaven', an ideal modern community. In films, cities of the future come with a warning about what might happen if we fully adapt to the modern ideals. ${ }^{33}$ The rich and famous will retreat into ghettos of perfection while others are left in the dark world. While cinema scripts absurd visions for the future, often times these dark unrealistic future speculations shape our present reality from wonders of space travel to frightening apocalypse. ${ }^{34}$ 
The Beach, 2000. Film. http://www. nicksflickpicks.com/thebeach.html, Accessed,

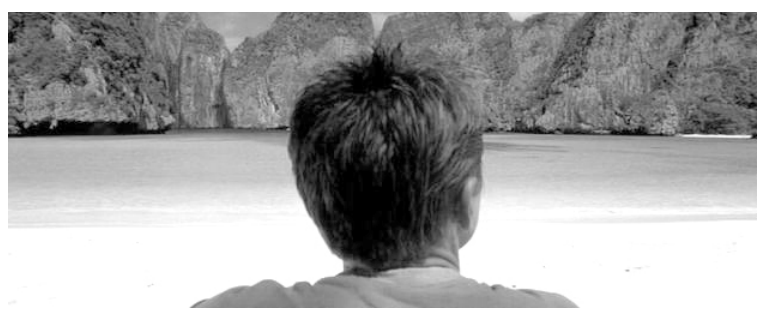

November 11, 2015

The ultimate escape from the fabricated apocalypse in our mind is not isolation; the cinematic depiction of an individual in a deserted island. Retreating to a primitive estate to find authenticity and perfection is in fact a pseudo-life stripped of all that is real. The $24 / 7$ society $^{35}$ pushes us into constant activity and eroding forms of relationships and political expressions, damaging the fabric of everyday life; the never ending struggle to search for meaning and ideals. ${ }^{36}$ Cary further explains that the non-stop process of twenty-firstcentury capitalism has devastating penalties. ${ }^{37}$

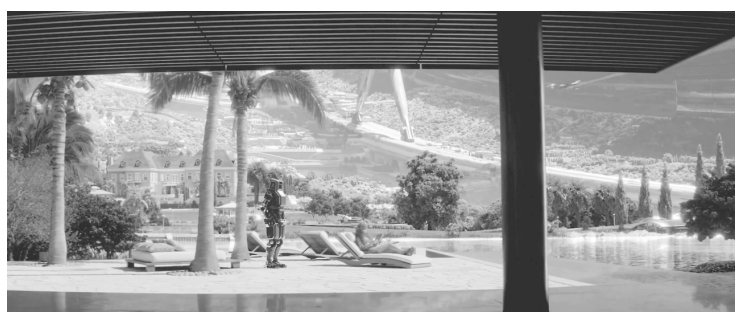

Elysium, 2013. Screen Shot. http://

leftfilmreview.net/2013/08/10/elysium-2013/,

Accessed, November 11, 2015.

Cutting down on working hours and purifying leisure periods will be the ultimate solution to stop the everlasting rat race. Newton's 3 Laws of Motion, with every action there is an equal and opposite reaction, best described by Tilda from The Cloud Atlas (2012) 02:34:10 "from womb to tomb we are bound to others, past and present, and with each crime and kindness we birth future."38 
The Day the Earth Stood Still. 1951. Screen Shot. http://www.moviemail.com/film/56610/ The-Day-The-Earth-Stood-Still-(Wise,-1951), Accessed, November 11, 2015.

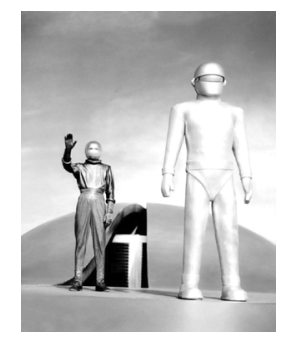

We always try to give character to our ideals as a testimony to our dreams. Meanwhile, if escape or primitive authenticity is already within us we don't need the technological support to embrace salvation. Utopia cannot be external but it is deep within us. This is the core structure of The Neon City, a platform to embrace the imperfections to harvest a spiritual or even pantheistic community where everything and everyone is connected.

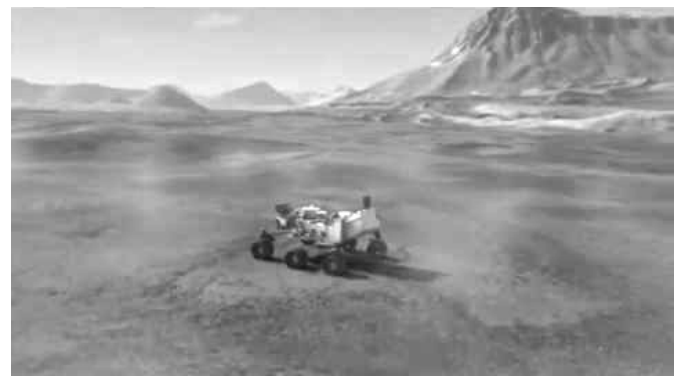

Life on Mars One Day to Mars 'Curiosity'

Landing. August 04, 2012, Screen Shot. http://

www.moviemail.com/film/56610/The-Day-

The-Earth-Stood-Still-(Wise,-1951), Accessed,

November 11, 2015.

"Cloud Atlas," 2013. YouTube video, 1:38, January 28, 2013, https://www.youtube. $\mathrm{com} /$ watch?v=0rQaQAsn6gM, Accessed, November 11, 2015

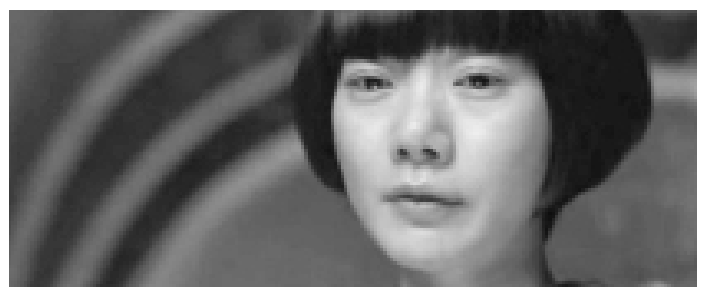




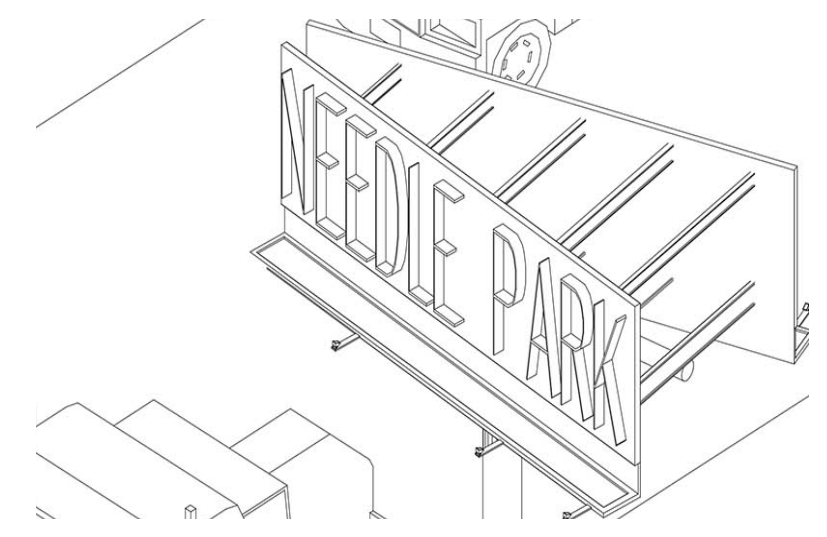




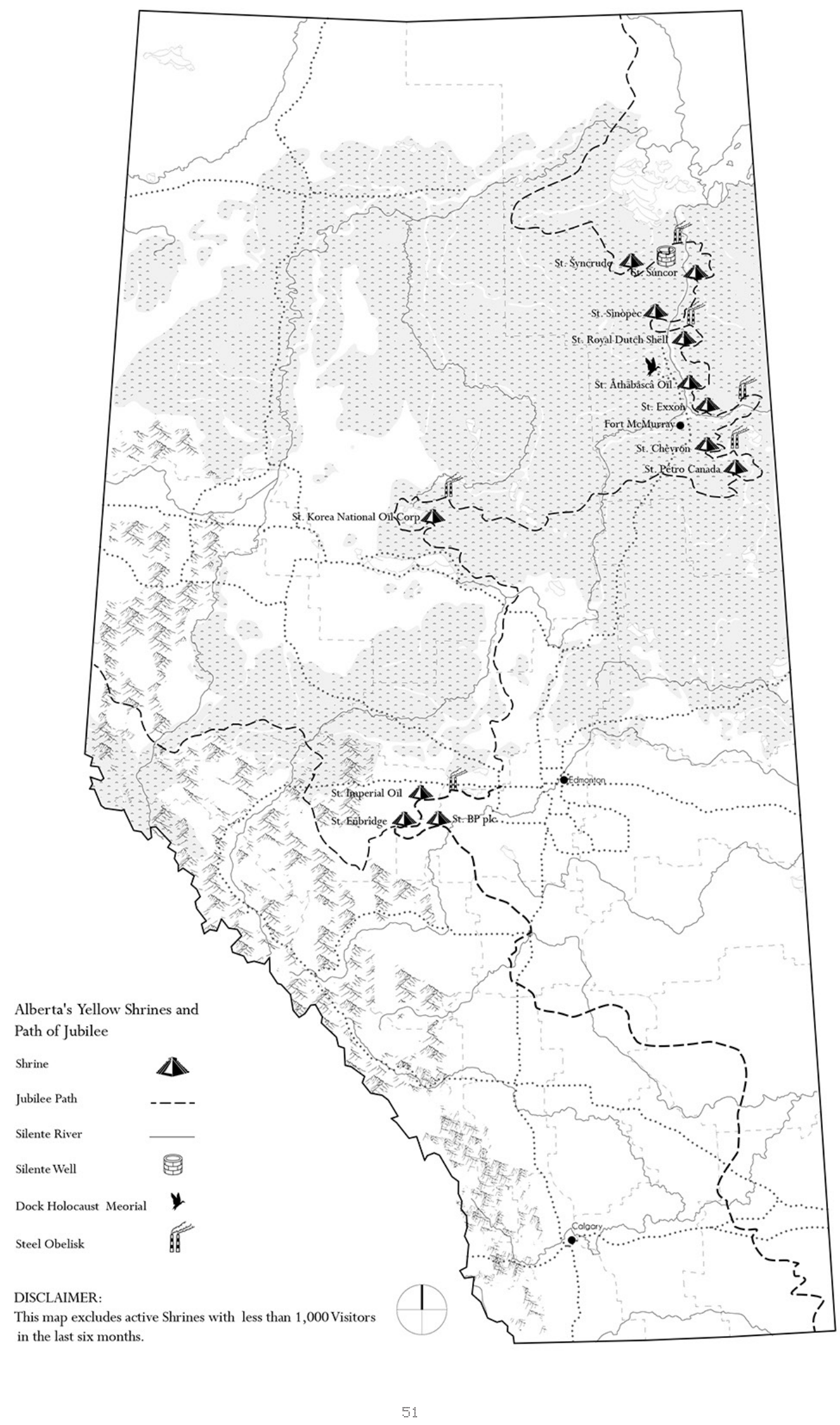




\section{YELLOW SHRINE \\ PART 4 \\ "Look at spirit, how it fuses with earth, \\ giving it new life $e^{139}$ \\ -Rumi}

Yellow Shrine relies on the strong foreign worker program to build the wonderful shrines and keep the spirit of the gods and goddesses alive through the collection of offerings and holy sacrifices. Worshippers offer jars of dirt as indulgences. This new territory of religious ground is a key element in providing good fortune and spiritual support for all. Yellow Shrines establish a new religious journey which brings hope and faith to New Alberta.

Keywords

Imam
Monks
Blasphemy

Sanctity

Love

Religious Destination

By-Product

Pilgrimage

Indulgence

Sulfur Dust

Sacrifices

Sacrilegious

Jubilee

Haji

Relic scarce 


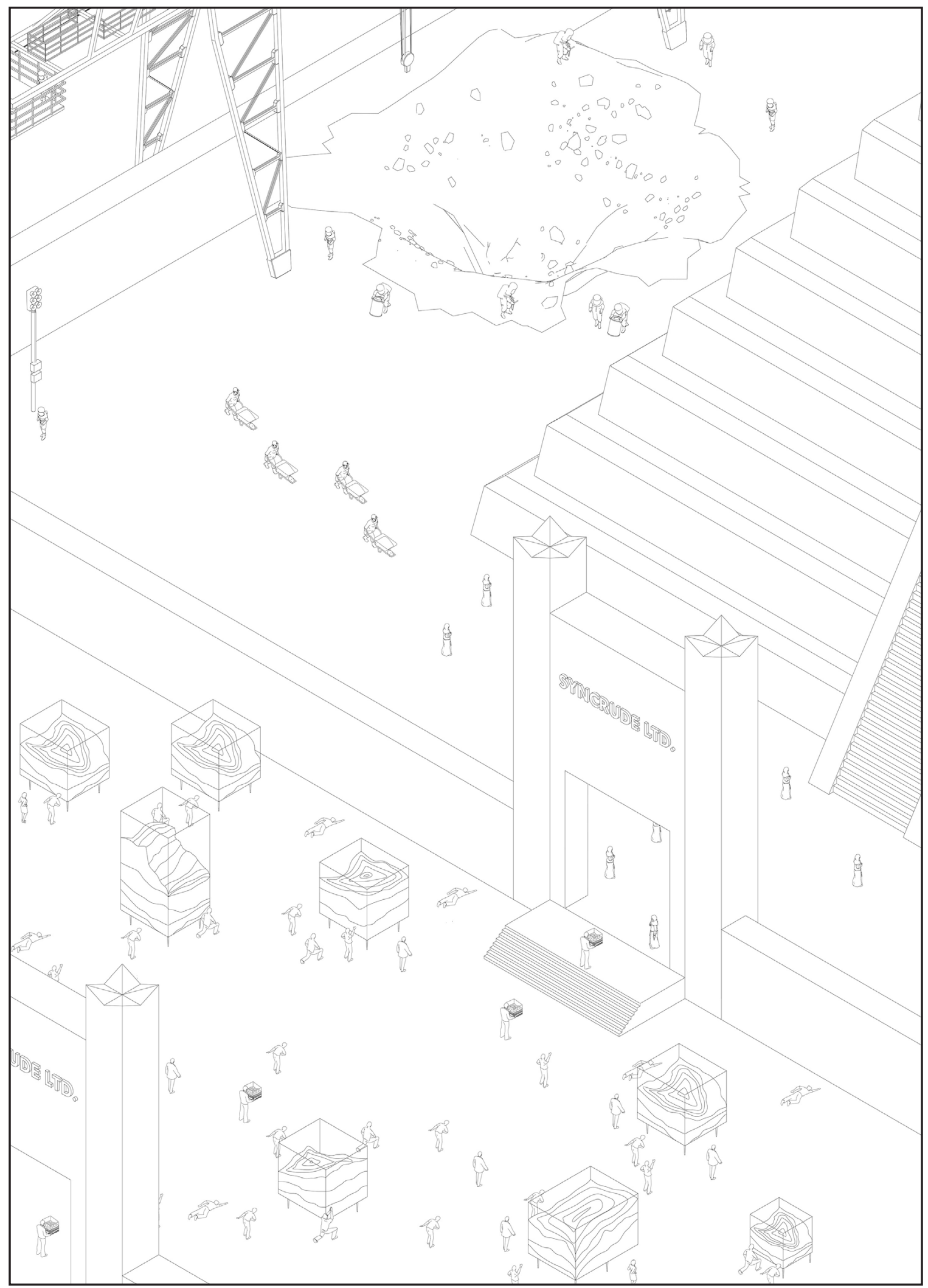




\section{YELLOW SHRINE}

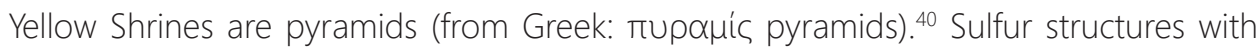
triangular outer surfaces which meet at a single point, making a pyramid. These are commonly constructed as ziggurats, built by the foreign workers of Alberta under the supervision of Supreme Albertan Monks for local religious ceremonies.

Pyramid design in Alberta has been around for decades, but it has only gained attention since the oil bust in 2050. The distribution of weight in the construction of the Shrines allowed architects to create stable structures, lasting for eternity. More recently, it was shown that the common shape of the pyramids of Alberta, from Fort McMurray to the southern parts of Calgary, represents the dry-yellow stone construction that requires the least human work to displace. Yellow shrines offer a significant contribution to the new ecology of hope for Alberta. They provide good fortune and spiritual support for all locals and visitors.

Yellow Shrine relies on the strong will of the dedication of the foreign workers of Alberta; to build the most wonderful monuments of the highest honor. Every other year sulfur worshippers are obliged to take the religious journey across the sacred Jubilee path cleanse their souls and pay tribute to the gods and goddesses who bring good

health and fortune for all mankind. Collection of offerings and holy sacrifices are of the highest honor among the Monks of Shrines. The worshippers offer jars of clean dirt as indulgence. These jars are transferred to supersize vitrines made of the finest, clearest and most expensive glass in the Great White North. Jar City like you have never seen. 
Worshippers must enter the sacred ground through a very specific path paved long ago by the compassionate and merciful founding fathers of Alberta. The loyal Hajjis of the Shrine invest time, faith and scarce fecund soil as an offering to the shrines at the end of their jubilee journey, in the hope of replenishing the colossal eradication of land by the prehistoric civilizations. Yellow shrines establish a new pedagogy of belonging and patriotic vanity. The Shrines represent the treatment of an epidemic land insolence that was once spread across the globe, infecting every living soul.

On special occasions such as Victoria Day and Civic Holidays - and of course the Jubilee year - Monks spend days and nights in trance. Since they are obliged to walk and bless the visitors, the inhalation of high concentrations of sulfur dust from the main courts may have harmful effects on their respiratory systems. Younger Monks and the general public are forbidden from entering the courts around the perimeter of the pyramids. Young Monks spend the first 10 to 14 years of their devotion cleaning the vitrines of purified soil. After everything that is all that is left of land in these high grounds!

Once the Hajjis pass through Jubilee Path and pay homage to each of the 12 Shrines they rest at the Silent Well before they head for St. Šyncrude Ltd. Shrine. The final Shrine is where they give their offerings and cleanse their souls. St. Šyncrude Ltd. has been around for hundreds of years yet no one really knows where the name came from; perhaps it is named after a fearless Monk who devoted his entire life to the construction of one Shrine. 


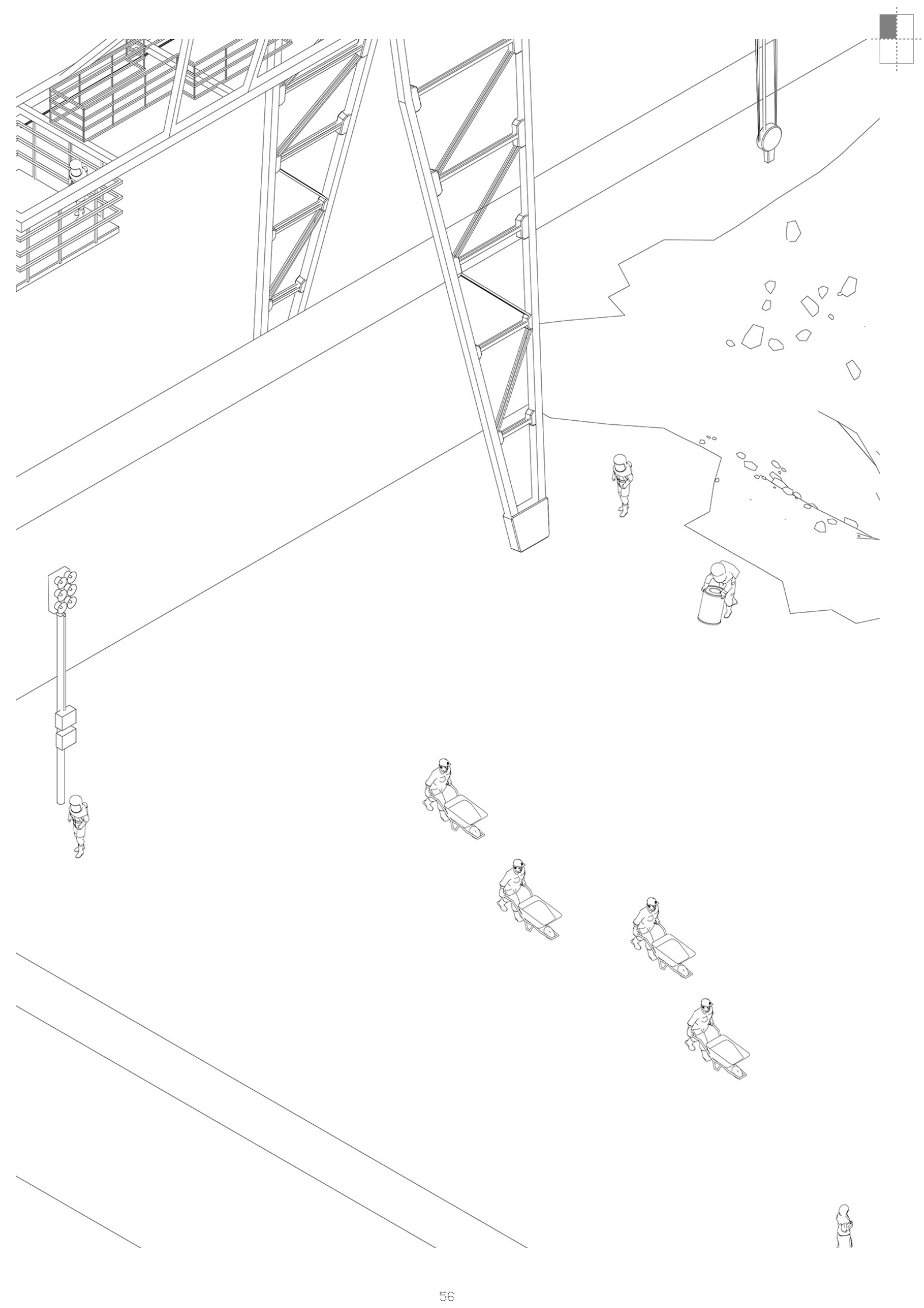




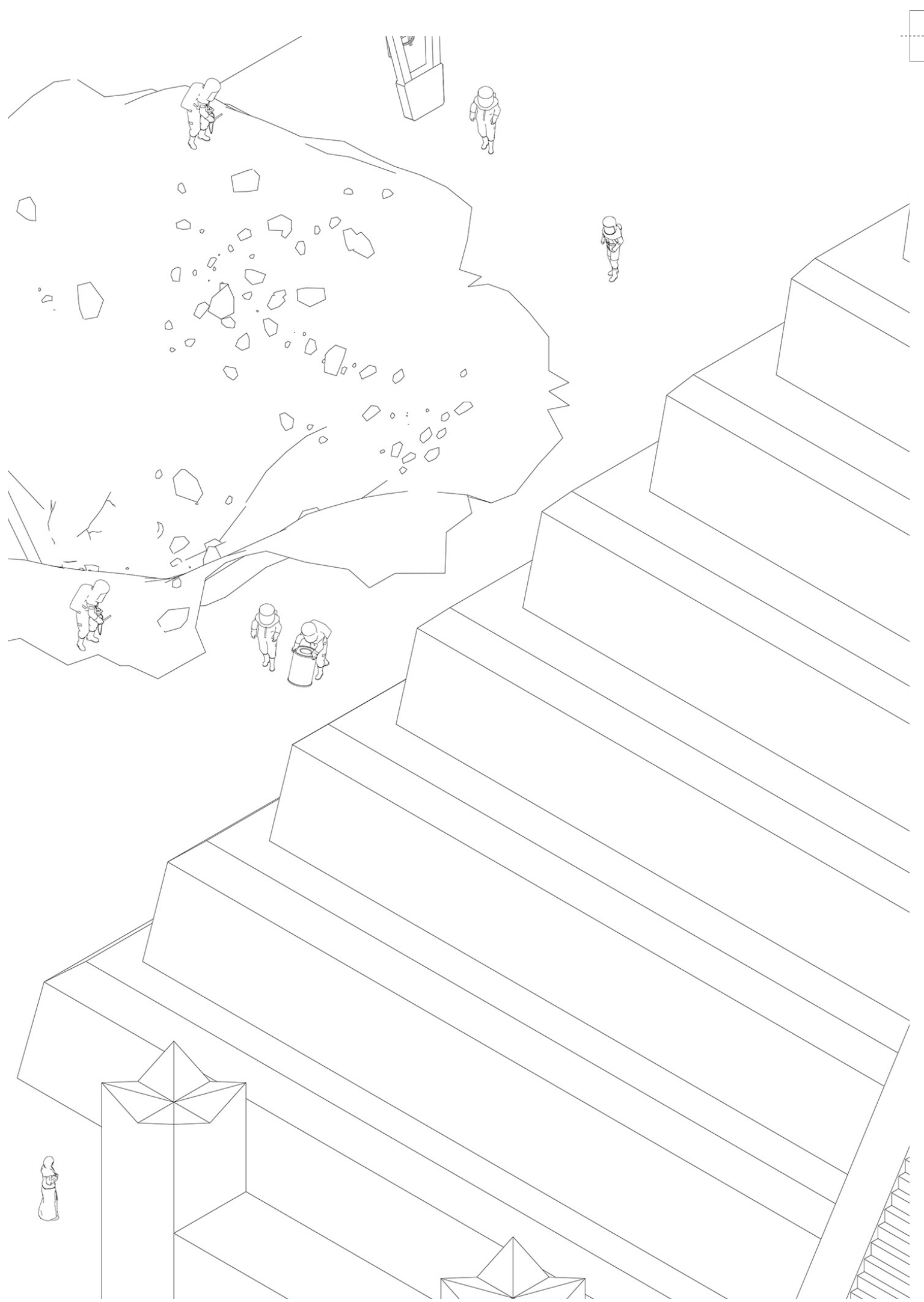




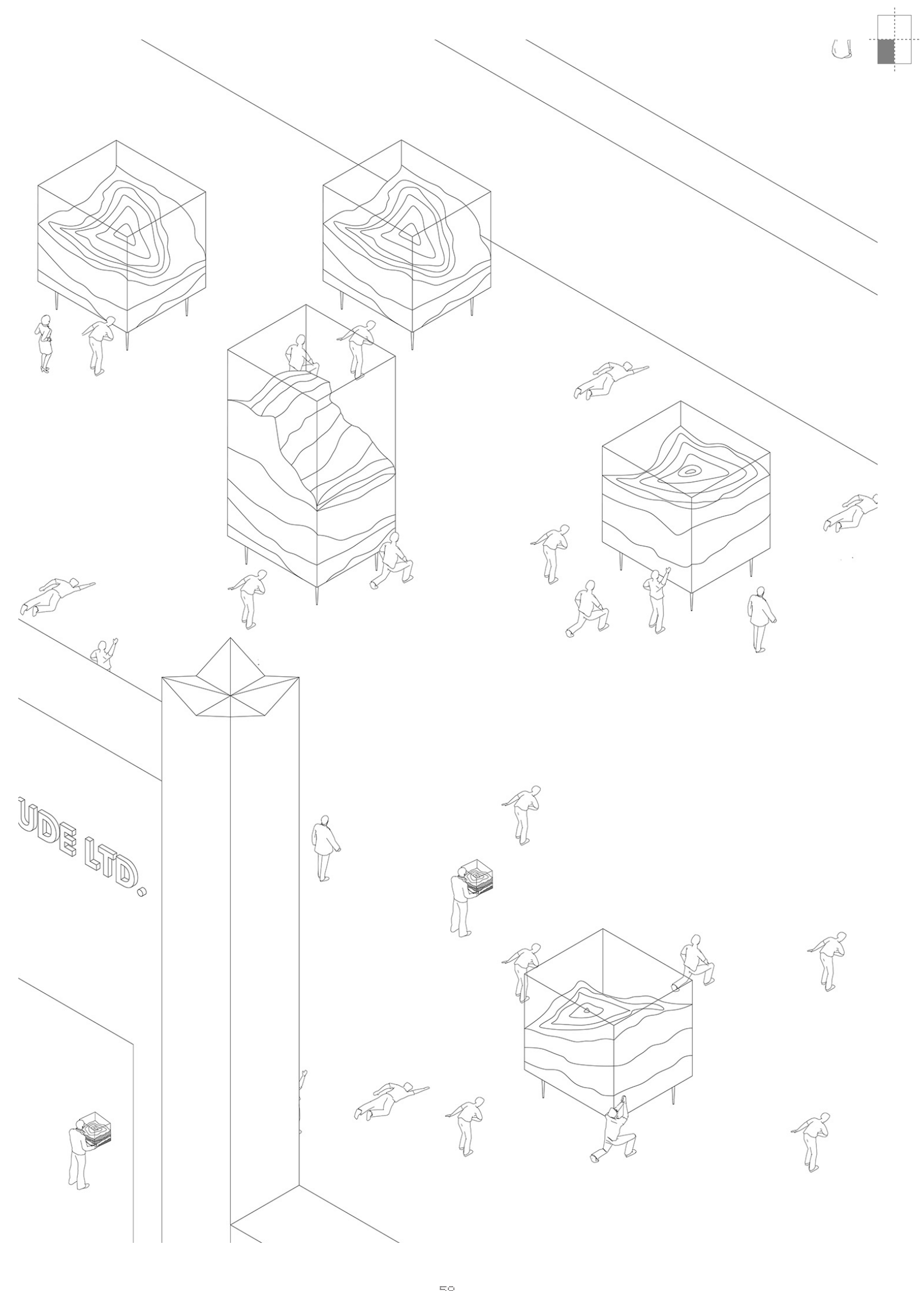




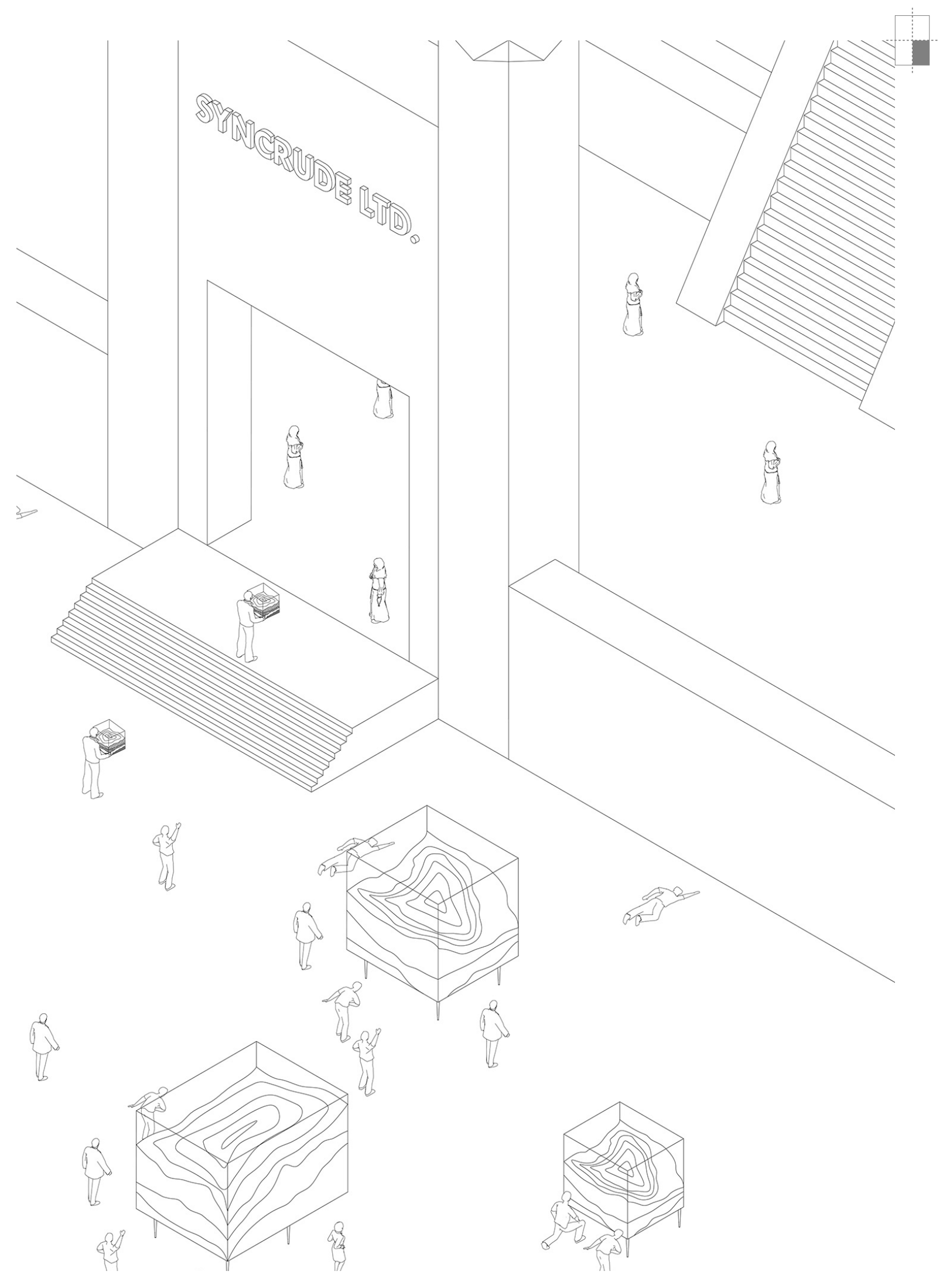




\section{NOTES}

Fig. 1. Sulfur Vat, Southern Alberta, Canada. Christoph Diewald. 2006, Digital Image. Available from Flicker: https://www.flickr.com/ photos/chris_diewald/(accessed October 20,

2015).

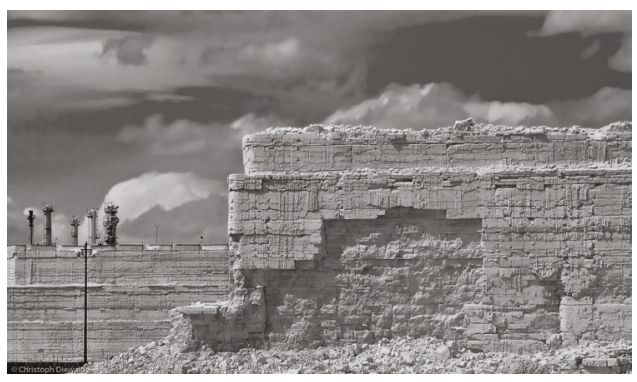

Alberta's Yellow Shrines are continuously smelting and refining one of the most vital elements of life, sulfur. The Alberta oil sands Industries produce more than just crude oil; in fact, they are producing vast amounts of sulfur stored in open storages. ${ }^{41}$

Unlike Java, an Indonesian island where molten magma streams at $600^{\circ}$ cover the surface of the Volcano and the island's eastern edge shrouded in blue flames of spontaneously-igniting sulfur, mine workers collect sulfur fearlessly from the mouth of the creator, while Kawah ljen is belching its volcanic gas. Most of Canada's sulfur is obtained as a by-product of the preposterous and profligate production in Alberta. ${ }^{42}$ Canada with its oversupply of sulfur is the second largest producer of elemental Sulfur after the United States. ${ }^{43}$

\section{Great Pyramid of Giza}

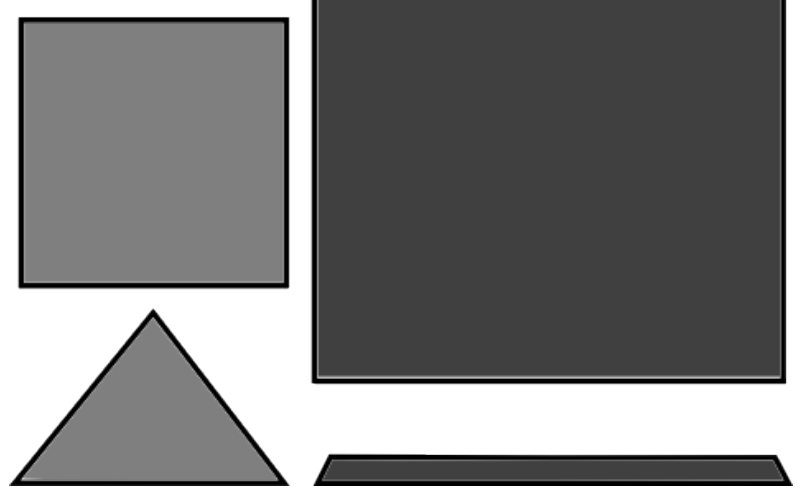

Fig. 2. The Great Pyramid of Giza and the Alberta Sulfur Pyramid, to scale, Andrew David Thaler. Source: Southern Fried Science. 2006, http://www.southernfriedscience.com/wpcontent/ uploads/2012/10/pyramid-400×312 png (accessed October 20, 2015). 
For 3800 years the Great Pyramid of Giza was the tallest man-made structure of any kind, until the Industrial Revolution. Since then buildings started to dwarf the great pyramids at 2,580,000 cubic meters in volume. The Yellow shrines of Alberta were not built to entomb a mighty king yet they stand as the largest (by volume) pyramids in the world. ${ }^{44}$ The largest Yellow Shrine has a quarter mile long base, and stands at 60 feet in height.45 The Illustration below shows the scale of Yellow shrines compared to Khufu's tomb: According to Energy and Capital, a research publication based in Baltimore, the Government of Alberta has new plans for mass producing sulfur in Lamont County, Edmonton. The plan is to construct a \$35million dollar shipping hub that would receive pure molten sulfur on a daily basis. The molten sulfur would be cooled in special facilities and shipped out in "loads of 3,000 tonnes per day from a mega terminal to Vancouver".46 From Vancouver the sulfur could be exported overseas. Perhaps sulfur pipelines would be the ideal solution to deliver and safeguard against the risks associated with the transportation of sulfur.47 

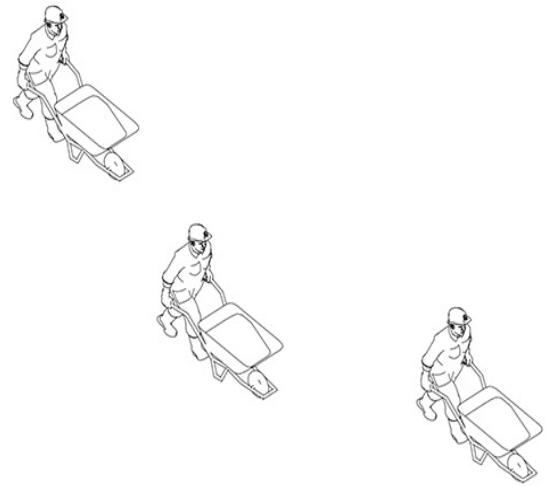


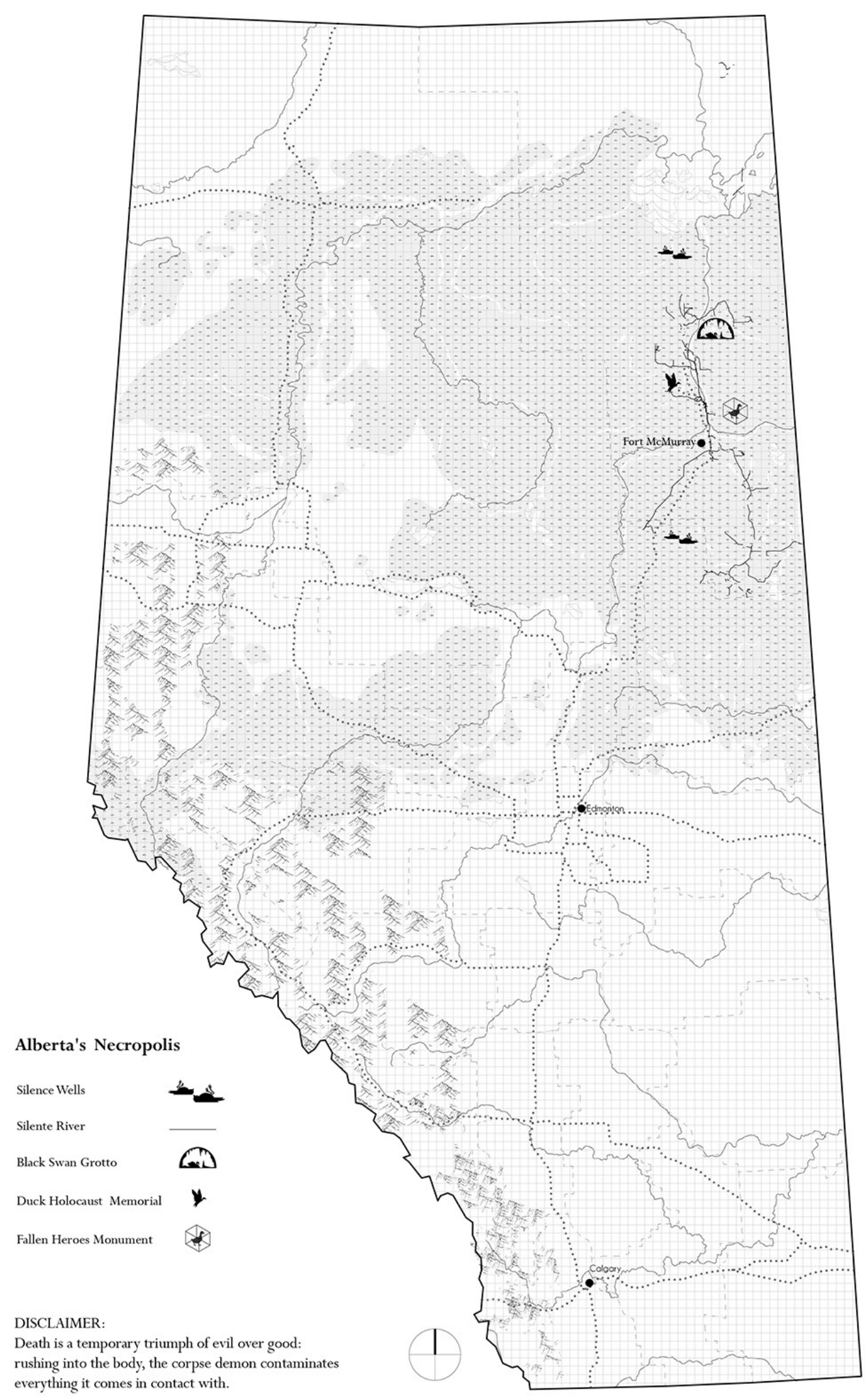




\section{THE LITTLE DUCK HOLOCAUST/ NECROPOLIS PART 5}

"Look at spirit, how it fuses with earth, giving it new life" 48 -Rumi

Necropolis is a dark, wet territory made up of a complex accumulation and compression of various types of carcasses. Body parts collide in an entropically generated landscape, creating a territory that can be ravished from multiple points of view. Abandoned skeletons built up over years resemble the prehistoric leftovers of an ignorant civilization. Yet this new territory is the most visited in Alberta, due to the lavish art of taxidermy. Necropolis can be best described as a mass burial territory exhibited in vitrines.

Keywords

Holocaust

The Machine

Carcasses

$\begin{array}{ccc}\text { Children's Story } & \text { Fable } & \text { Industrial Folly } \\ \text { Resources } & \text { Temporary Workers Program } \\ \text { Bodies of Land }\end{array}$

Rise of

Necropolis 


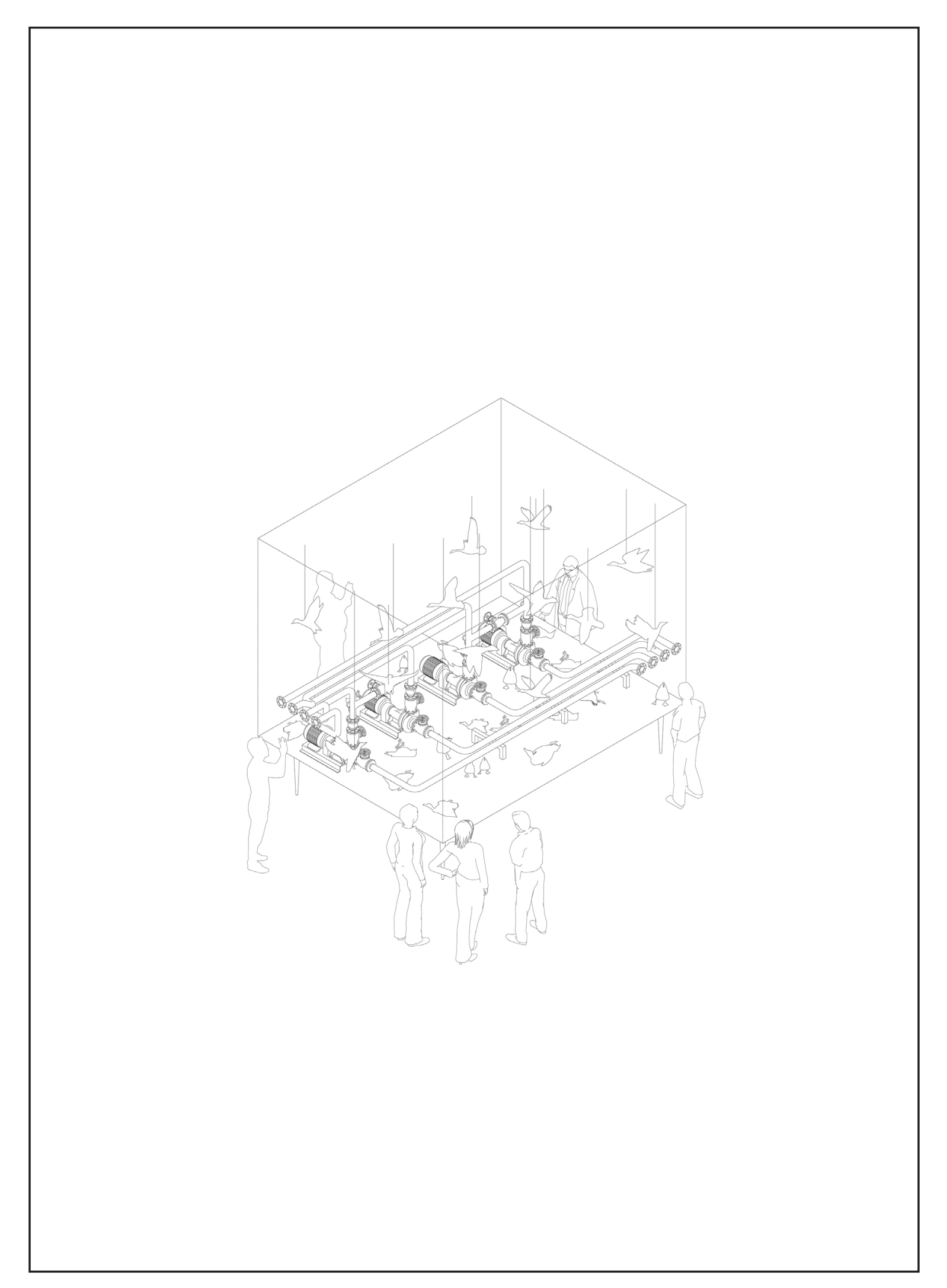




\section{THE LITTLE DUCK HOLOCAUST}

I would like to introduce you to Necropolis, an extreme landscape of sandy wastewater and tarry air. Necropolis is a dark and wet territory made up of a complex accumulation and compression of carcasses. We are in an amorphously fluctuating terrain of hydrocarbon states. As a visitor you undoubtedly spend the majority of your day looking into our land through a protective glass, either from your seat on the tour bus or from your hotel window. Firstly, if it wasn't for Suncor and Syncrude you would not be here visiting and given this privilege in the first place. I am sure you have noticed these esteemed industries on your way into town. Their main refineries and upgrade facilities are located about a quick trip up Highway 63, which runs parallel to the Athabasca

River, a little idyll past the evergreen hills. Sometimes, the noxious tarry atmosphere punctures the air like cannon fire.

I was originally from a diving duck family, generally called pochards or scaups. Our survival depended on diving beneath the surface of the water and catch fresh fishes of all kinds. Diving ducks in The Great White North are part of Anatidae, the diverse and very large family that includes ducks, geese, and sometimes swans. We are placed in a distinct subfamily, Anatidae. Morphologically we are closer to the dabbling ducks, which live mainly on the surface of ponds and lakes rather than diving and flying. There are some pronounced differences between us and the dabbling ducks especially in our structure of the trachea. We are fairly distant from each other, the outward similarities being due to convergent evolution. ${ }^{49}$ 
As a visitor you might not notice me amongst the rows and rows of my fellow duck divers, and I may appear trivial to you, let me assure you I have my own story. I was born in February 10 th 2006 in The Great Black North where the inhabitants used to be the craftsman, craftswomen and other artisans in the tar territory. We all belonged to the family of Anatidae, and we enjoyed spending time on lakes. We love to please as we fly amongst those tall dancing chimney-like exhausts, putting huge emphasis on choreography and singing. However there were and are dangers. A simple missed prompt in our performance can lead to death. As a duck, our biggest fear used to be the sound of a 12 gauge waterfowl hunting shotgun, but today our biggest fear is our own reflection in a tailing pond.

I am now physically unable to travel across this world. I have an idea of it in my mind as stories are passed down from our ancestors - the most privileged position to be is of course here in the North. My mother tells me stories of how they used to migrate almost every year, from the Perry River district to the central Arctic coast of Canada. The first part of the journey in the fall crossed the barren lands to the Great Slave and Athabasca lakes, then south to the northern boundary of Montana. They then turned southward to cross the Rockies on their way to the wintering grounds in the Sacramento valley of California. ${ }^{50}$ 
However, now with our grand visibility near zero, we tend to lay low and forget migration my grandparents would become nostalgic as they spoke of times when there were far less smoky grey clouds, and they lived in much wider lakes with no gooey glutinous ponds. Today as our world's fly zone is getting smaller and smaller, we are packed closer together. The population boom happened over three generations and we have doubled in size. Some say our lack of desire for migration is the cause of our Hybridization, when our genetic compositions drastically change by in-breeding, mating with our close relatives making those less common extinct. ${ }^{51}$

I know I shouldn't be complaining in comparison to your world, your fast paced web of highways, race car ya-yas and roads where an exponential growth in efficiency and physical labour makes it even more traumatic to live. Flying up from the ground of this man-made world, the atmospheric layers here present quite a unique climate. The first impression you will notice is the vivid lush green pines that are rapidly disappearing, where the air is thicker and thicker, when truck lights flood through man-made crevasses. We worship the dark skies with both awe and fear, interpreting the reflective ponds and scarecrows as the Gods and smoke stacks as our fate, like poker players in paradise.

The Great Black North is a paradoxical place. The vast landscapes and greenery seen from afar unfold into a disappointing illusion as soon as you reach Highway 63 and drive towards what you think is land. Sometimes - you will begin to understand why 
the longer you stay here - we see ourselves as performers of a brave but fake ecology, mimicking natural authenticity and presenting it to create the delirious attraction of poker-worlds beyond the wildest imagination.

We are told that our ancient ancestors lived in a lush landscape of fresh water and fertile terrains. Yet our own world has evolved to one scarred by the highest form of spatial movement by those man-made machines. You too may be proud of how far you have come, thinning our surface, operating with more efficiency and equality, but we know there is still a long way to go. They say our land has black gold buried deep under layers of overburden. Well surely, it is a burden for man to move 150 meters of soil with their tectonic shufflers!

I often think now about our future and the importance of my kind in this new territory. Predominantly over the years, I feel the gods' needs have increased - they are more demanding and less tolerant. I feel as though the gods are bored by our simplemindedness. Do people really know what it's like to be a duck in this world? I mean we fly into these fake reflective ponds from time to time which are more than traumatic for us. And then imagine our unceasing fear of those boobies, those gormandizing duck hunters with their crack-deafening shotguns'. 
Let me tell you about an accident, it happened in the Southern districts some years ago. It is called The Great Genocide. Some 1000 refuge ducks were escaping the greedy hunters and on their way to find new home landed on a tailing pond. By accident, these poor ducks thought they were landing in a freshly melted iced lake. Boom! Catastrophic! For a while no one knew about them until recently. Now, every souvenir store has a perfectly formed plastic duck key chain. Although this was one tragic event in our short history, I think it helped us to be recognized worldwide. Since the opening of the museum, a variety of new jobs has been created. There are now more shotgun stores and taxidermists, who, I suppose, are doing their best to prevent those unwise, premature ducks from landing into the ponds.

They are shot down mercifully and some are even offered to artists to allow the silly ducks a chance of permanent happiness. The artists are generally taxidermists. They surgically remove feathers, flesh and bone and carefully practise stuffing ducks with lifelike effects; this has the added advantage of making them forever happy and looking young. The bones are often thrown into the giant dried wells. They say black gold was made of bones and animal remains.

I have to say to you all here on this trip. I often wonder what it is like being stuffed and exhibited in vitrines for all visitors to see. But then again I don't have too much time for an existential crisis. 


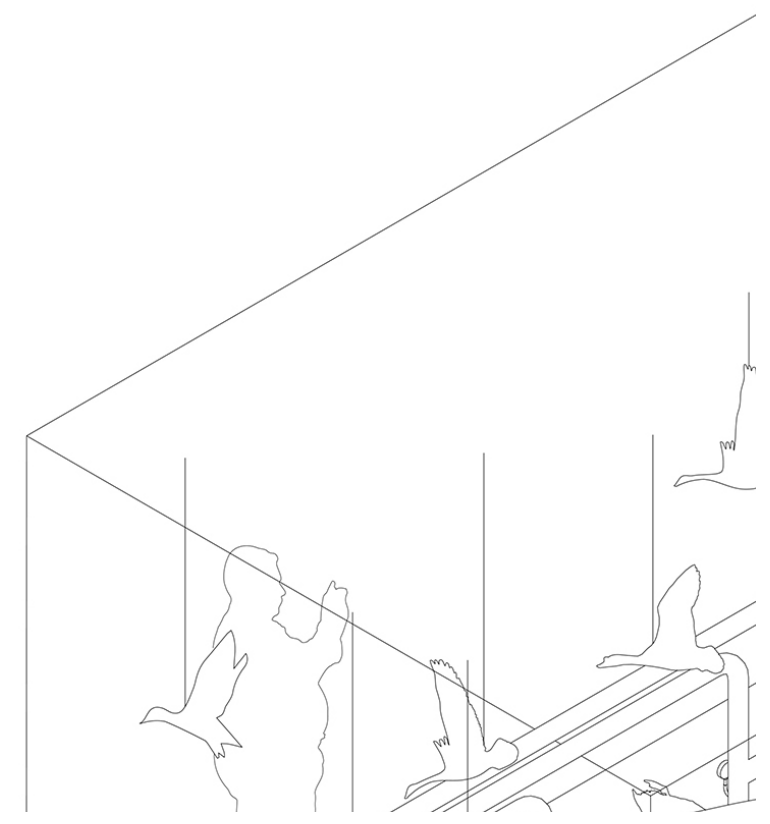




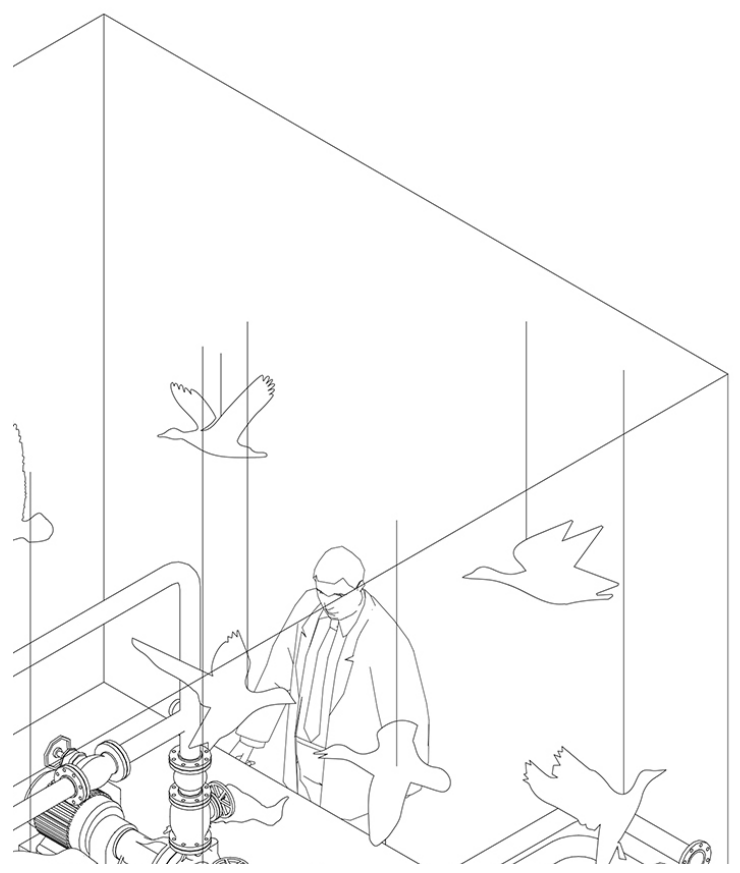




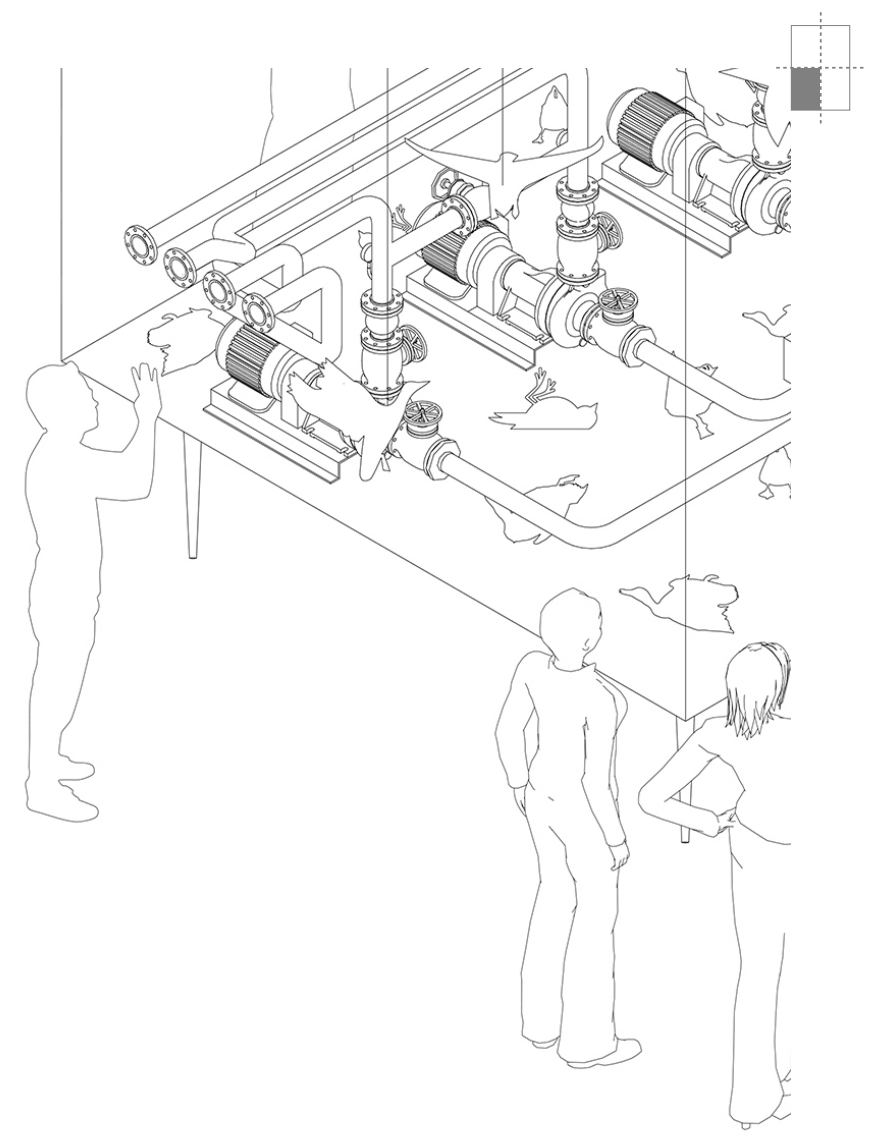




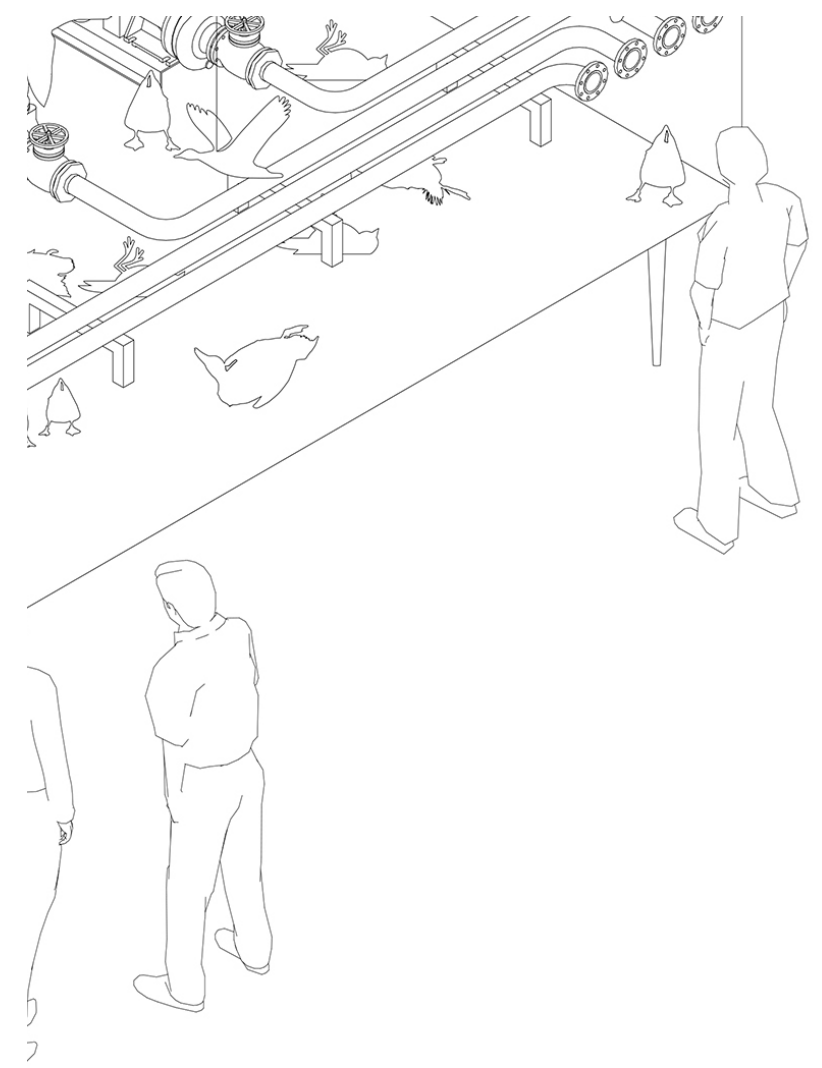




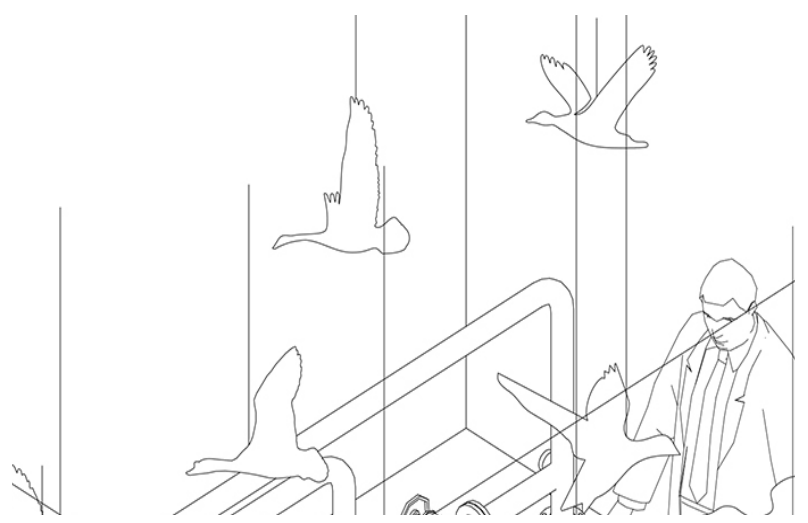




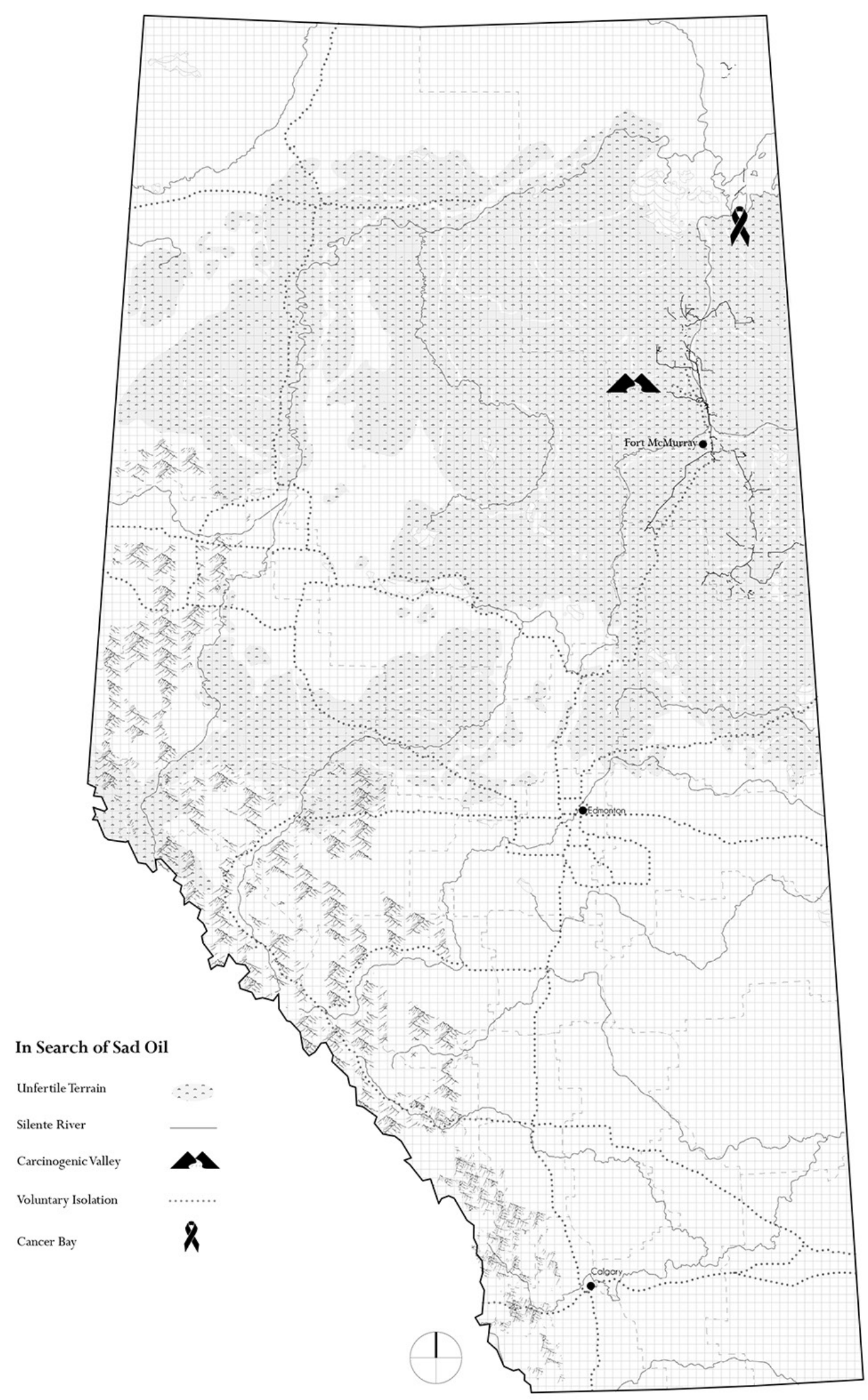




\title{
IN SEARCH OF SAD OIL \\ PART 6
}

\author{
"Please God, let there be another oil boom. \\ I promise not to piss it all away next time." 52 \\ -1980s Bumper Sticker
}

The most fascinating aspect of sad oil in New Alberta, this voluntary isolation, is that it transforms an idyllic toxic land into an extraordinary theater of ephemeral anxiety. This new ground becomes an unfertile terrain a landscape of extreme experimentations, thus proposing a new ecology of hope and life in a heavily polluted gluten-free carcinogenic land. Here, only time offers stability, an escape from the anxiety of uncertainty.

Keywords

\begin{tabular}{|c|c|c|c|c|}
\hline Royalties TAX & nd & Uncertainty & tile Terrain & Ecology \\
\hline Experimentations & Idyllic & Hope and Life & Free Trade & Post Disaster \\
\hline Reconstruction & Нуро & thetical Landscape & & Rejuvenation \\
\hline A Self-Repairing Dementia & The & Oil Factor & & isaster Seasons \\
\hline Economy of Fear & Clash of $\mathrm{C}$ & Civilizations & Economic & Consequences \\
\hline
\end{tabular}




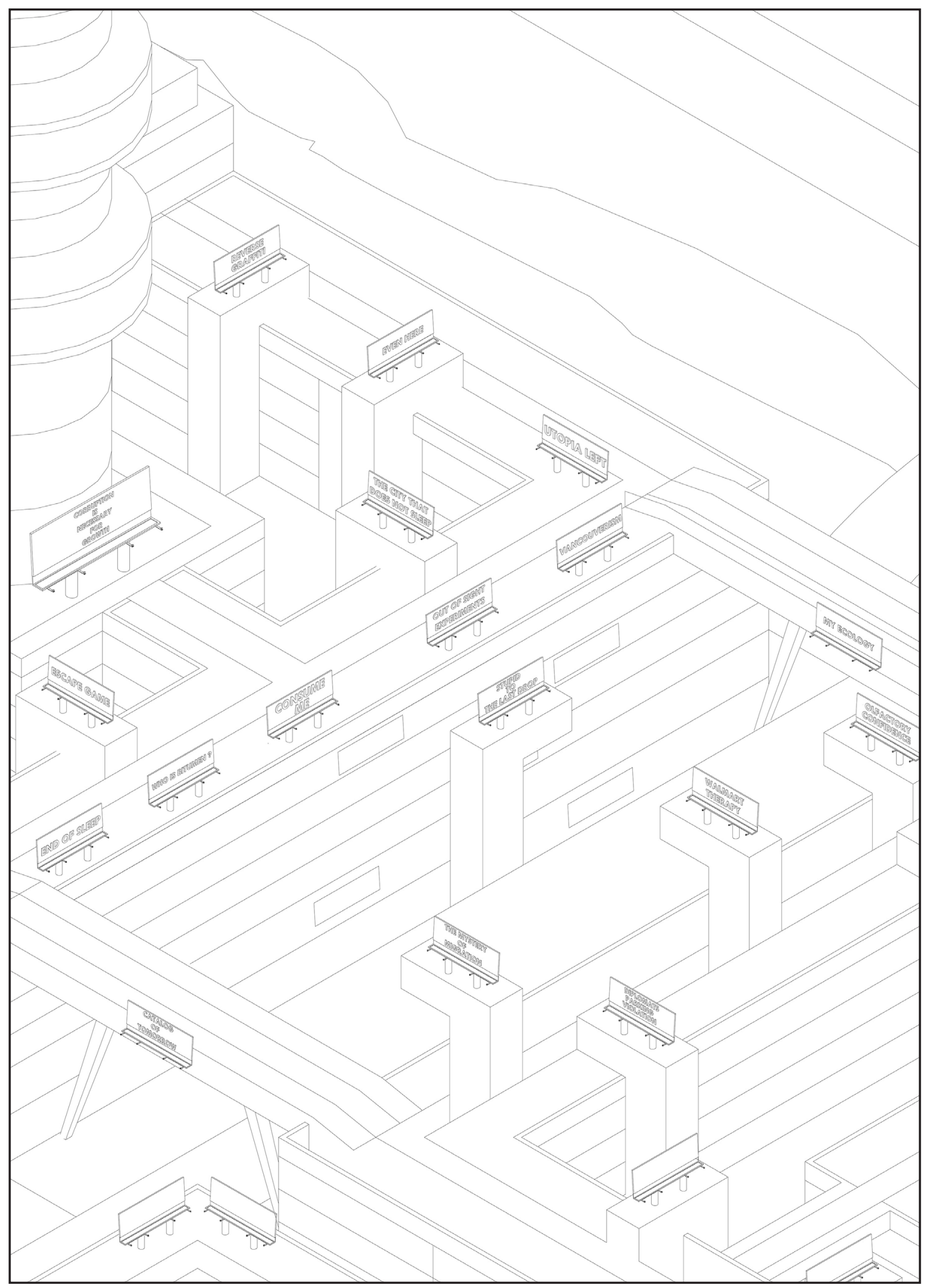




\section{IN SEARCH OF SAD OIL}

Once upon a time in a land far far north after the fall of the pantheistic communities in the Green Sybaritic Era, utopia was finally understood as a conscious state of mind. It was well rooted in each human being. All members of society and levels of government were self-aware and willing to claim responsibility for negatively affecting their landscape. All economical incompetence was abolished.

The Green Sybaritic Era made the entire Northern Territory sustainable with lavish green energy and ubiquitous clean technologies. All of which was not possible without CAT heavy trucks and electric shovels. However, the immense quantity of energy-efficient recycling bins, high water-efficiency-toilets, electric bikes, Nexus butlers and home grown handbags were not cheap.

Subsequently, almost all of these clean-goodies relied on Heavy Metal Minerals extracted by CAT Machineries, a group of rare chemical elements found in soil and their ample extraction from the earth's surface, plus the abundant increase in the worldwide demand, led to the shortage of Heavy Metal Minerals. It is worth mentioning that none of the G.E achievements would have been possible without Articulating Trucks, Dozers, Haul Trucks, Shovels and Draglines.

Virtually all the Heavy Metal Minerals were discovered in the 20th century; however their use commonly multiplied because of the availability of green technologies. Not knowing the possible catastrophic result of further mining of Heavy Metal Minerals, 
humanity celebrated its green achievement with delirious consumption of Nexus butlers and ios x video consoles. Until all the Heavy Metal Minerals were gone.

In the First World Assembly of Scarce Resources, Board members drafted the commandment, which was signed and respected by all countries. After a long conference, the undisputed vote was upheld to embargo Heavy Metal Minerals mining and to memorialize the tragedy by making new boundaries for the toxic landscapes left behind. Since the last World Assembly, all nations recruited special exploration teams in search of alternative energy sources.

Sad Oil is a territory of possible escape, a memorial playground that represents the hope of recovery and reconstruction since the embargo. The most fascinating aspect of Sad Oil is in New Alberta. This voluntary fantasy transforms an idyllic waste land into an extraordinary theater of ephemeral anxiety. 


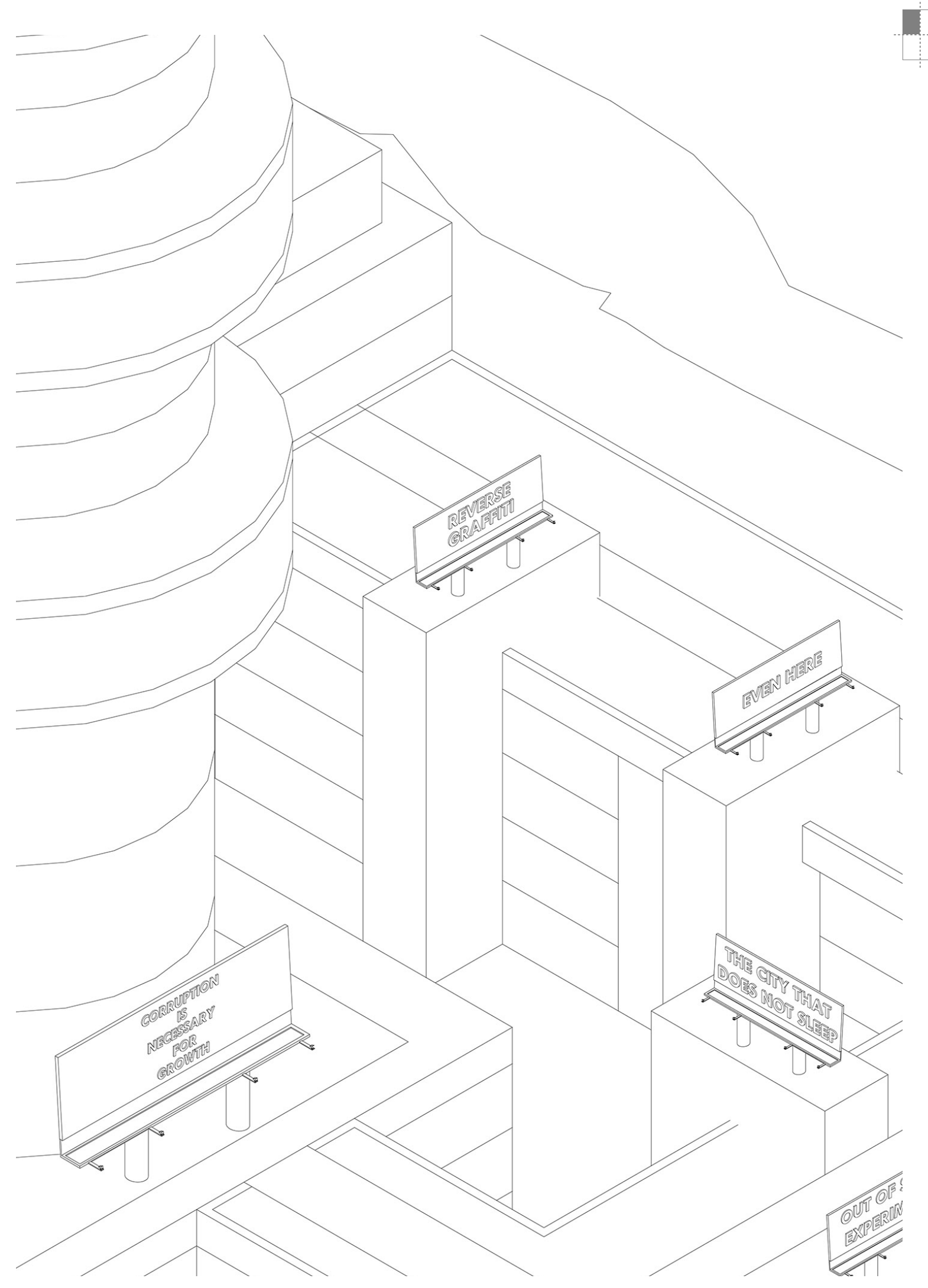




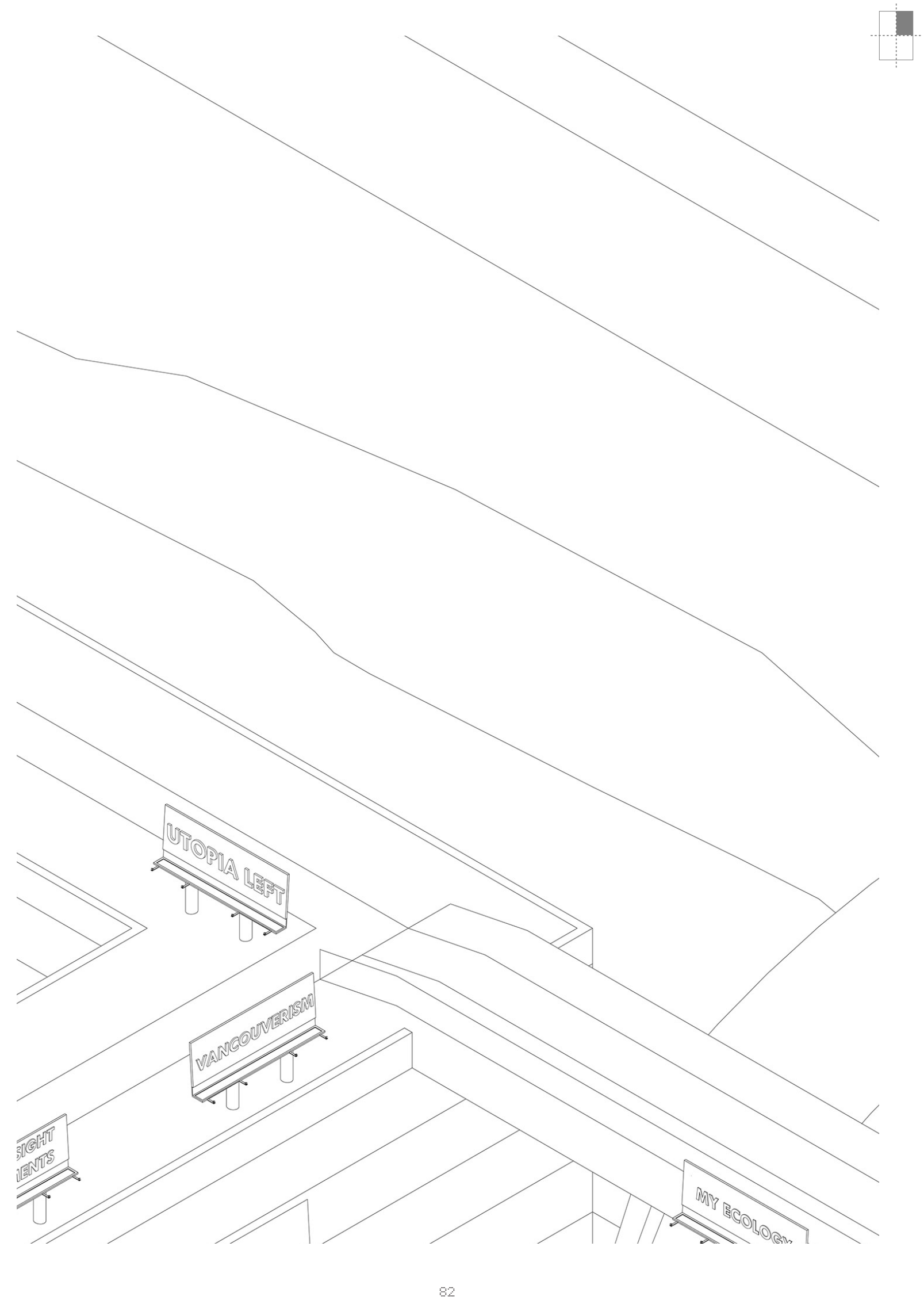




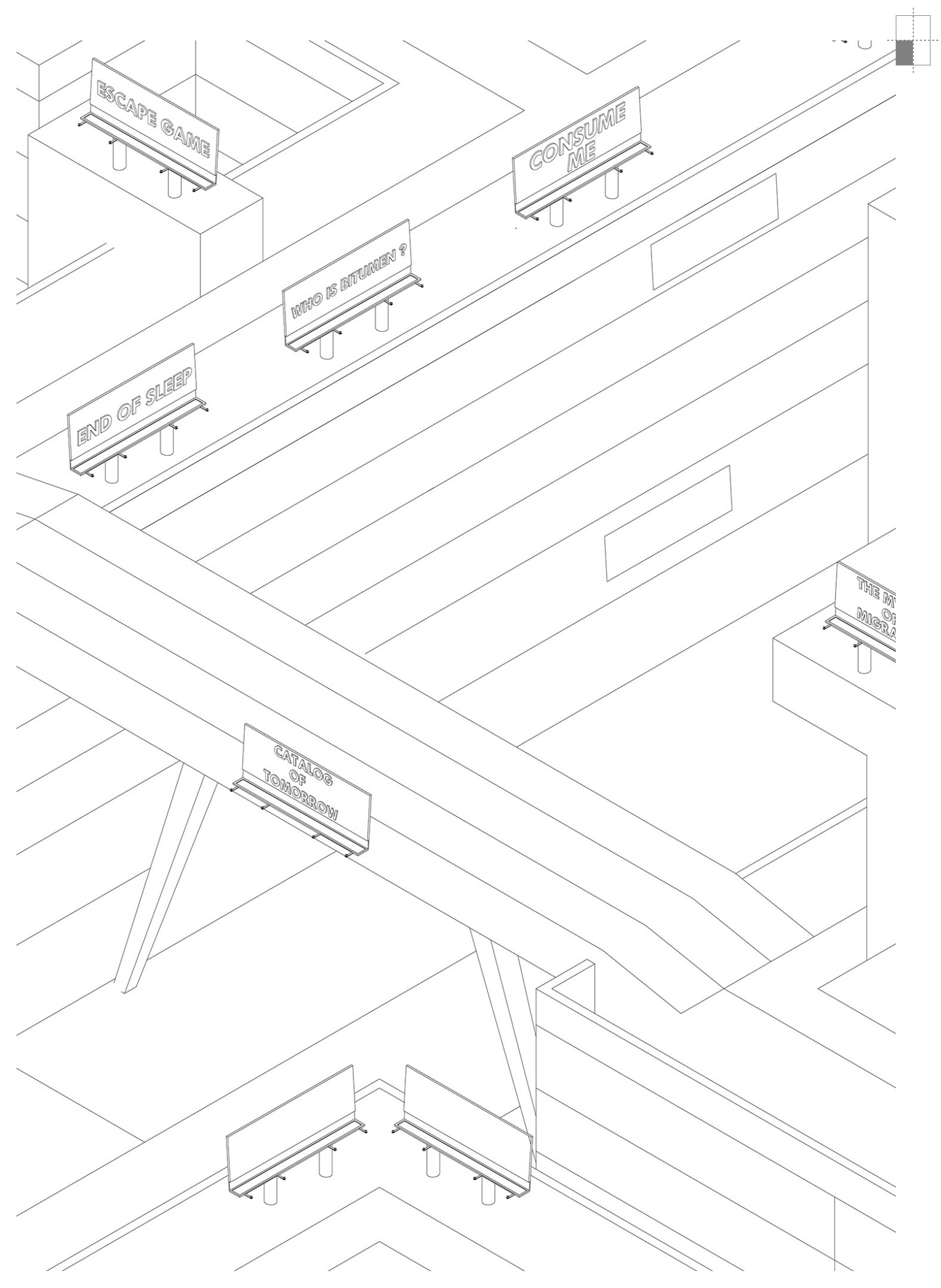




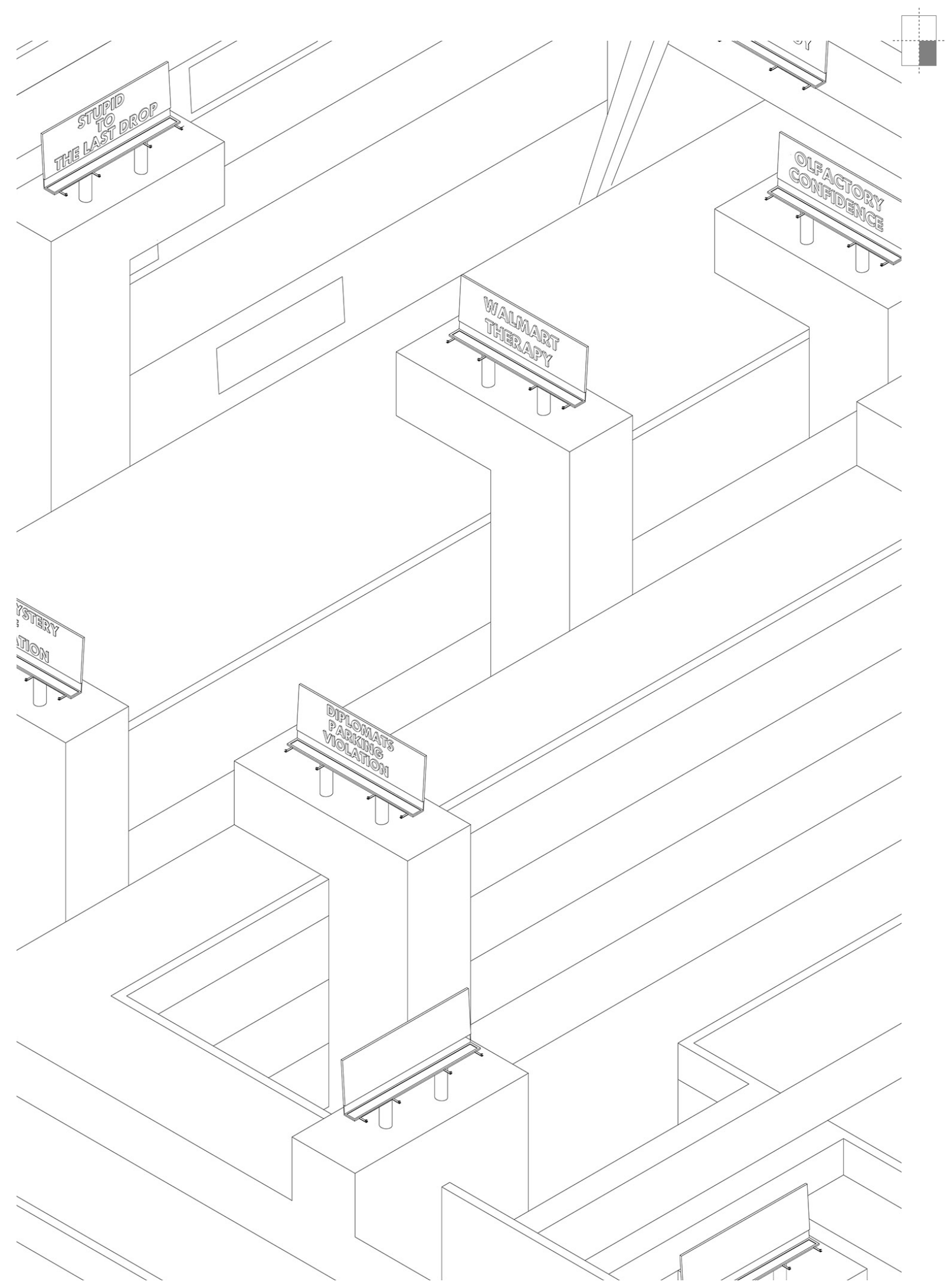




\section{NOTES}

Beneath the various discussions of oil states and their control of the global finance, the oil sand industry has played a metamorphic role in reshaping distant landscapes of northern Alberta. Oil sand Royalties have converted Alberta's land into monuments of energy, casting superfluous geometries upon delicate topographies..$^{53}$

The narrative questions whether vulnerable territories of Fort McMurray can be reclaimed in a post oil future vision for Alberta. Furthermore, the fable aims to propose an architectural and landscape investigation that examines the existing toxic territories of energy companies. As oil sand refineries continue to scar large territories of land, the oil industry and the government of Alberta that empower them should respond to the impact of mass infrastructure extraction on the population of Alberta that produces it.

The basic definition of Petropolis is intimately tied to the notion of harvesting. The act of harvesting has primarily implicated two infrastructural formats: the surface (for gathering) and the container (for storage). The integration of these models, however, with other models of production is rare. While current Petropolis's

focuses on the harvesting of a primary resource, there are divergent views on the role of plural harvesting in terms of urbanism. Examining the role of systemic symbiosis within this context, the Petropolis of tomorrow is poised for deeper integration within a larger spectrum of networks that operate holistically. ${ }^{54}$

The Canadian Government is so deep within the pocket of the petroleum companies that Canadians know they cannot appeal to the government for environmental support to stop the land ravaging in the northern Alberta. Fossil fuel industry in the Alberta has only tapped less than $5 \%$ of the available dirty oil and it will not back down until they have it all..$^{55}$

The main argument of Alberta's government is to push forward the petroleum ravaging so that the oil industry creates jobs, speculating during economic crises. However the same economic system, the same economic model that puts greed above all, that liberates corporations and empowers multinational conglomerate to do as they please in the name of free trade, is threatening to crash the global climate system. This is exactly the same system that crashed the global market, which is why the global job market has soured. ${ }^{56}$ 


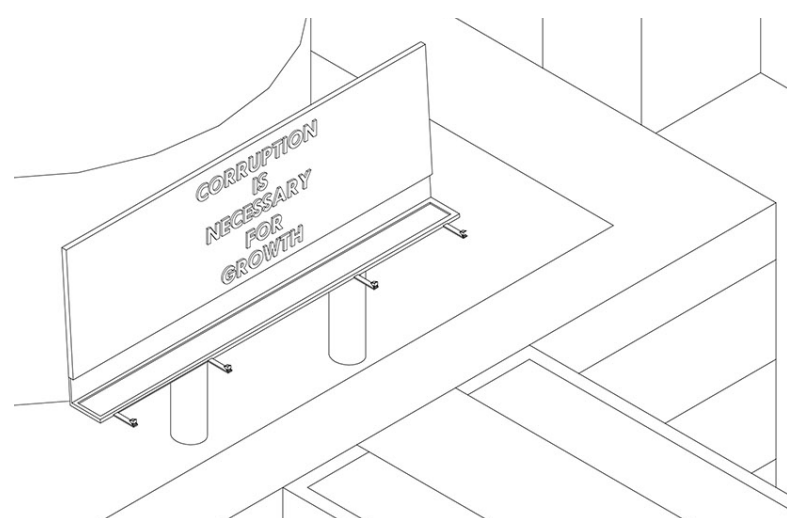




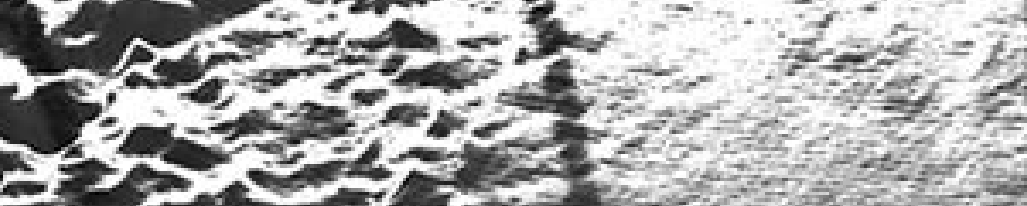

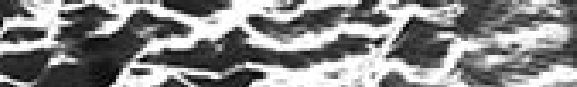

$2=3$

$5 a-14$
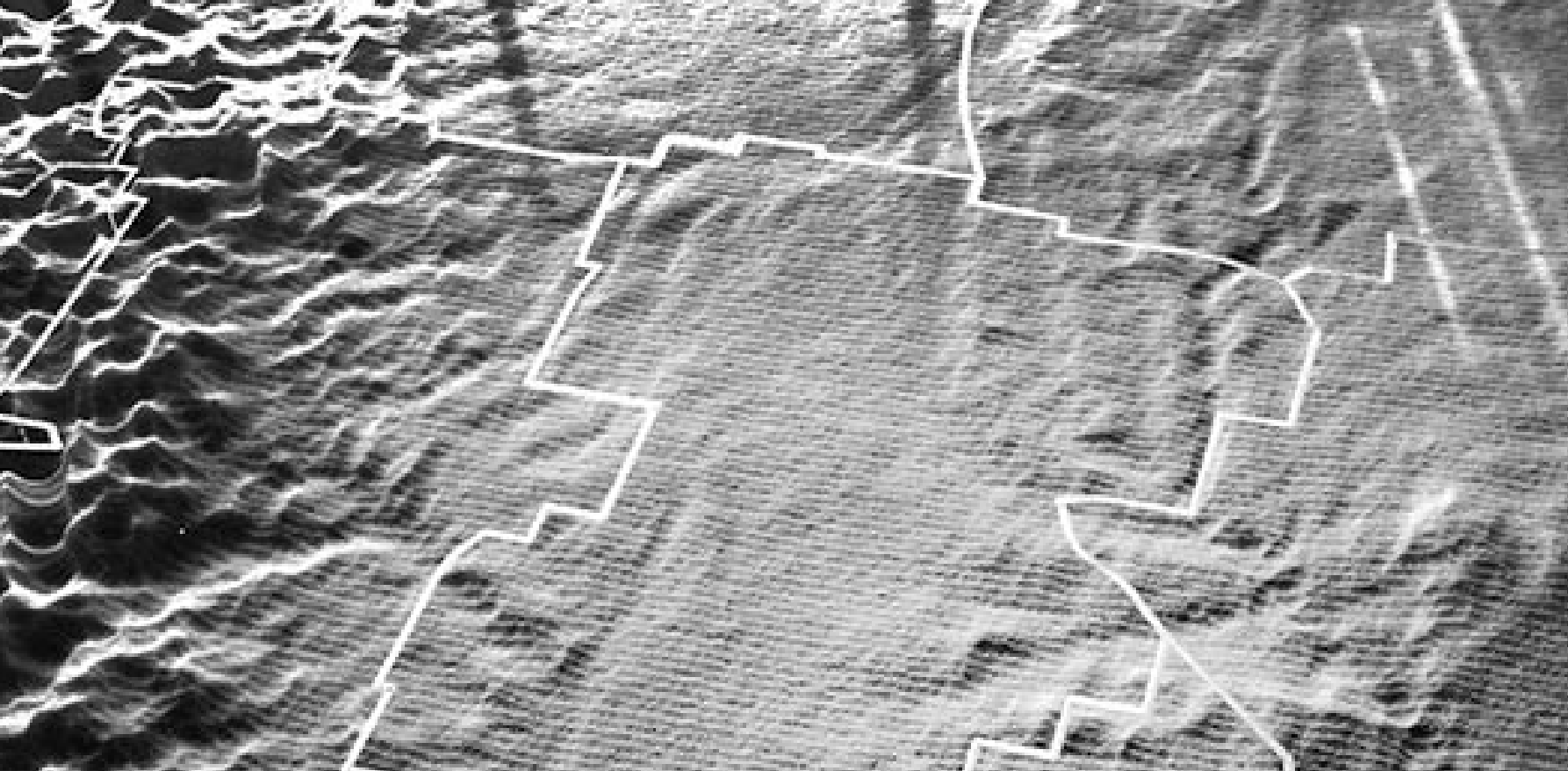

$x+5$

201474 $-x-2+3$

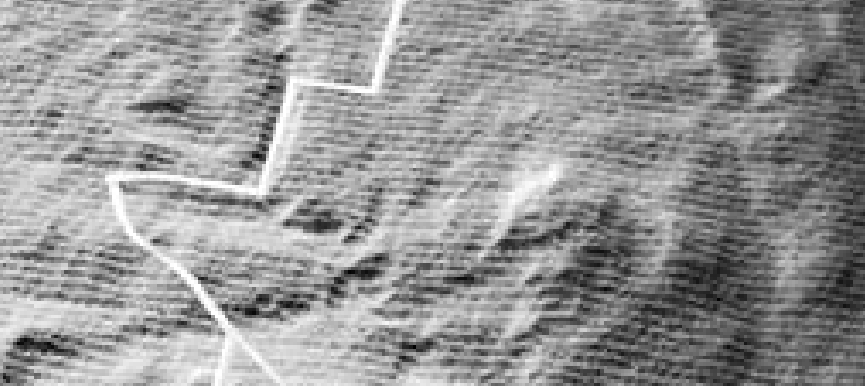

istos?

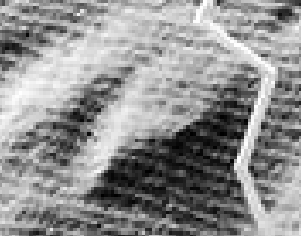

des : I

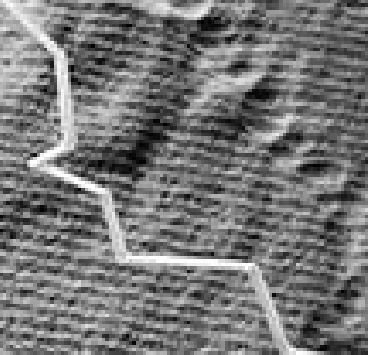

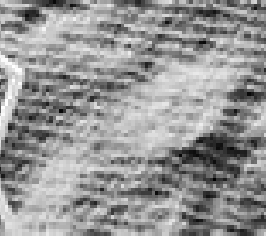

$\frac{3-3}{3}=6$

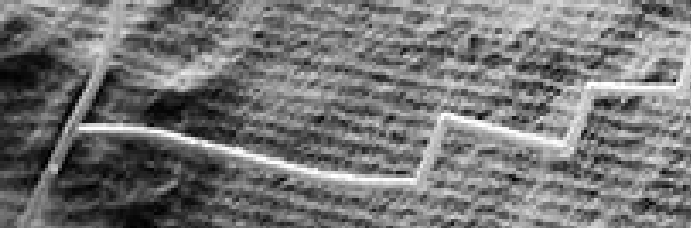

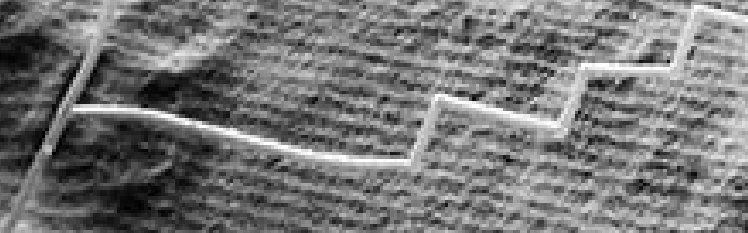

6rises:

3 entesin:

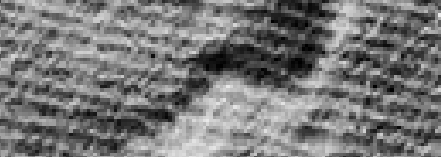

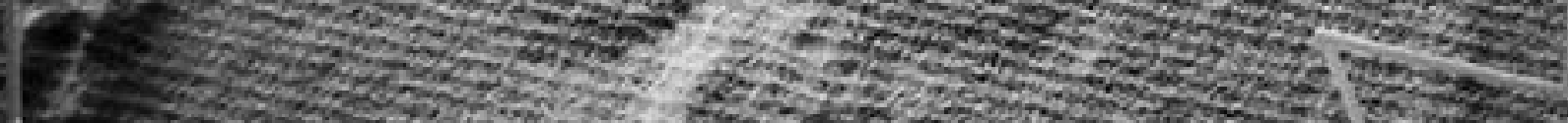

$x+x-2 x^{2}$ 


\section{FROM FICTION TOWARDS AN ARCHITECTURAL CRITIQUE}

Post Petropolis critically and fictionally speculates on the "potential" fallout from a dystopic Canadian industrial production. The context is Alberta after the Oil Boom. What will we be doing, imagining and designing after this orgy of production and immorality? What should be done with all the carcasses and disfigured land left behind once the industries have exhausted their resource? It is an overly simplistic question as a short exploration of the subject leads one to realise that each site is unique and has to be approached individually.

Who amongst us can offer ideas for the future or offer an idea for a place that has lost its original topography and any original vegetation is now utterly eradicated? Using drawings and texts, a critical narrative of environmental hopelessness in the current Alberta Oil sands is identified and the condition assessed ecologically.

Out of surprising and vibrant fictional ideas which act as a critique, suggestions are made to show how an expanded architecture can impact the future. To talk of remedies is perhaps naive but Post Petropolis moves from a carefully drawn and imagined satirical despair to a speculative, urban and architectural awareness. Blending critical fiction with reality, Post Petropolis raises dialectical issues of diversity against convergence, responsibility against irresponsibility and ethics against aesthetics. 
Post Petropolis will now focus on six final acts, frames and visions, examining a possible future for Alberta's landscape and its relation to energy consumption. These final acts provide environ-conscience archetypes through 6 different lenses. In response to the current ecological paradigm, Post Petropolis proposes a muted fiction pro tem. Irrespective of how real the techno-science behind each proposal appears none of the six fictional acts in this research provides easy concrete solution. The fabricated mythology and cynical humour in the archetypes is intended to explore how consumers narrate the Earth. The highlighted values in each act are left for the reader to draw their own conclusion. 


\section{THE HOMOGENEOUS TERRITORY}

TYPE 1

CORPORATIONS

\section{PROJECT: THE EPHEMERAL ECONOMY}

Built out of expandable space frame structures that keep the region intact from any sudden economical shift, the scale and pace of the Homogeneous Territory and the refreshed economical guidelines challenge the notion of permanence as a basic state of any province. These ephemeral landscapes of pop-up industries persistently increase and provoke the notion of "The City" as a permanent entity. The Homogenous Territory offers a new theory of social and economic principles with tentative expiration dates and a return to pre-planned obsolescence.

Text Inspired by Ephemeral Urbanism:

Rahul Mehrotra and Felipe Vera

Ibañez, Daniel, and Nikos Katsikis. Grounding Metabolism.

Cambridge by Universal Wilde, 2014. 


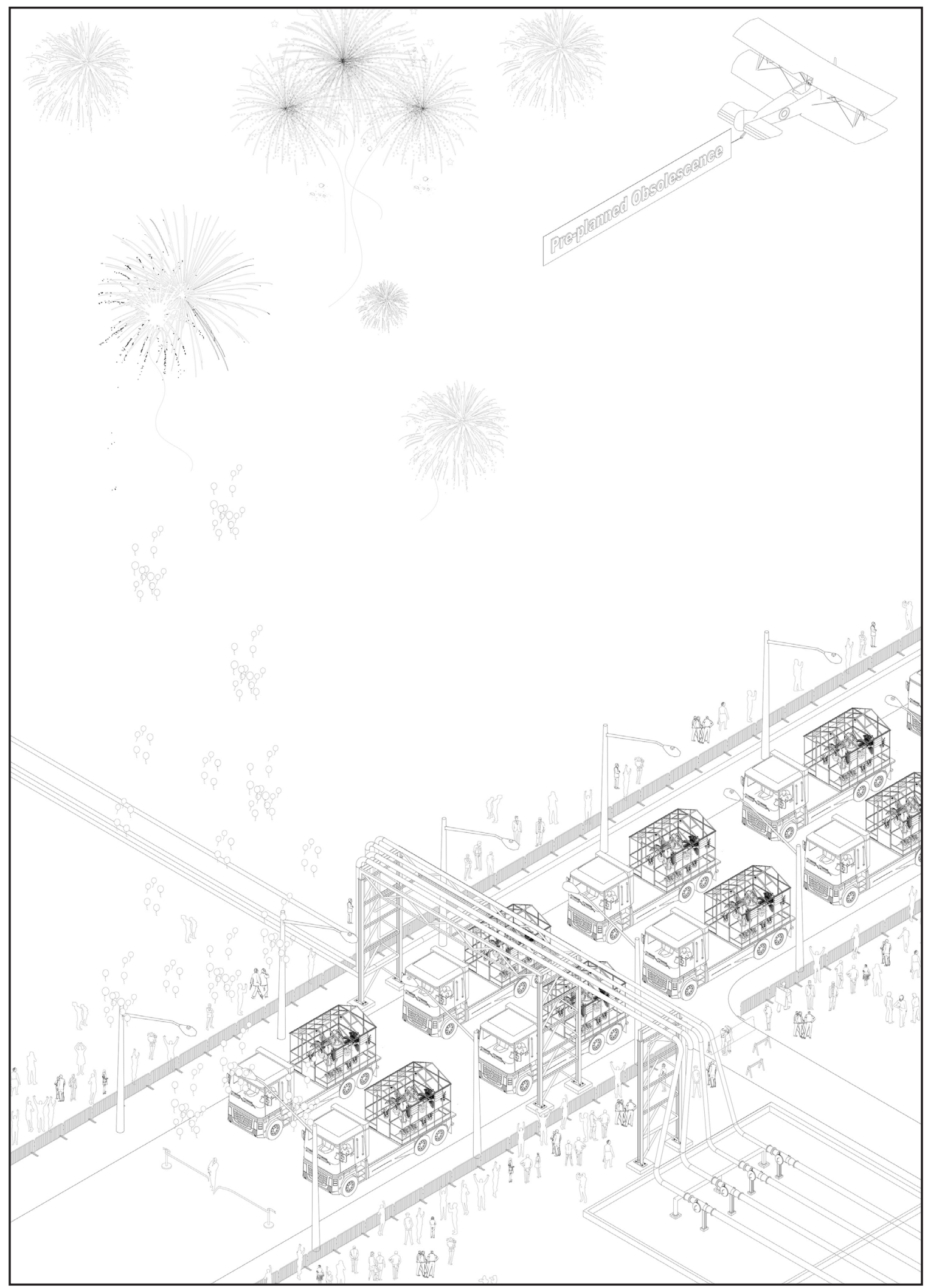




\section{THE HOMOGENEOUS TERRITORY}

The Homogeneous Territory of Alberta is re-built on the terraformed boreal forest of Northern Alberta and is the first territory built after economic austerity. There has never been a territorial reform at this scale since the Federal Cash Relief fund (2016). On January 16, 2016 Alberta's Dirty Oil extraction was terminated, precisely when Persia emerged from years of economic isolation, and the United States of America lifted crippling sanctions in return for the country to comply with a deal to control its oil market.

As the Albertan's landscape become ever more loathsome, a shift to Homogenization seemed inevitable. Technological breakthroughs in the pharmaceutical industry led to the invention of the "Super Pill" which was the cornerstone for the architecture of the most efficient economical system in the region. Every union representative received an abundant supply of the "Super Pill" to re-engineer all and every labour endurance.

Equidistant from British Colombia and Saskatchewan, both of which were by this time slowly rising from the ashes, the Homogeneous Territory orients itself towards the True North, taking advantage of Yellowknife's weather patterns and corporate taxation freedom. Built out of expandable space frame structures that keep the region intact from any sudden economical shift, the scale and pace of the Homogeneous Territory and the refreshed economical guidelines challenge the notion of permanence as a basic state of any province. These ephemeral landscapes of pop-up industries persistently increase and provoke the notion of "The City" as a permanent entity. 
The growing attention paid to the economic crisis and ecological issues have reappeared within Alberta's new landscape harnessing the anxiety occupying the recent emergence of corporate efficiency as a super-model for land reformation. Thanks to the "Super Pill" the Homogeneous Territory offers a useful organization platform with a range of elements that simultaneously support its continuity.

This new territory is structured around one main purpose. It functions as a central force that not only defines its philosophy and complexity but also determines essential characteristics, such as the life cycle of each corporation and its entire labour force, its material composition, and the place it occupies in the cultural context of Alberta in which it grows and operates.

As an extreme case of an ephemeral economy, the Homogeneous Territory of Alberta demystifies a distilled narrative surrounding the development of one province in time. The Homogeneous Territory acknowledges the need to re-examine permanent solutions as the only mode for the formulation of corporate efficiency. It posits new protocols that are perpetually reformulated, re-adapted, and re-projected in an iterative search for a temporary economy of survival that reacts to a permanent state of crisis. Thus the Homogeneous Territory offers a new theory of social and economic principles with tentative expiry dates and a return to per-planned obsolescence. 

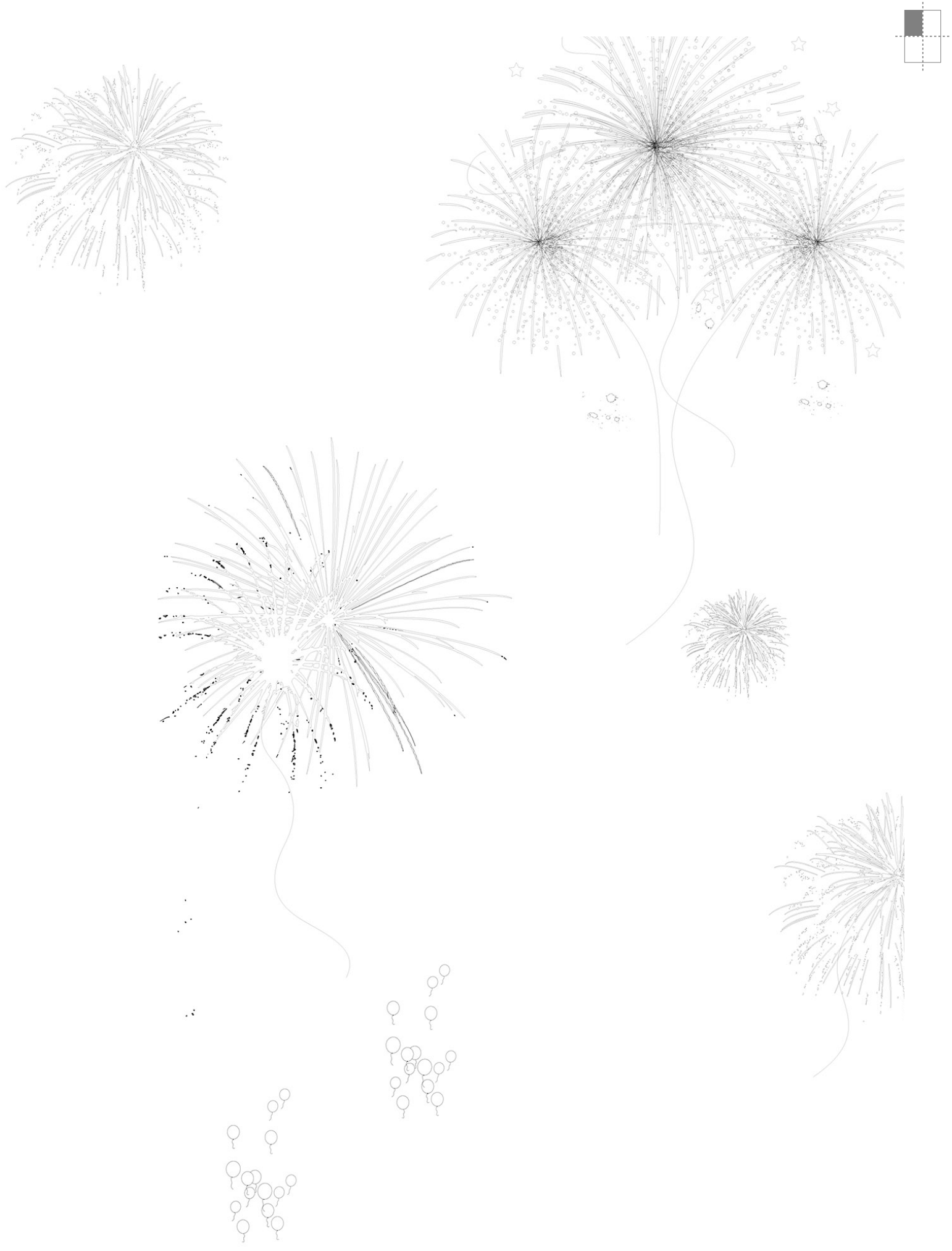


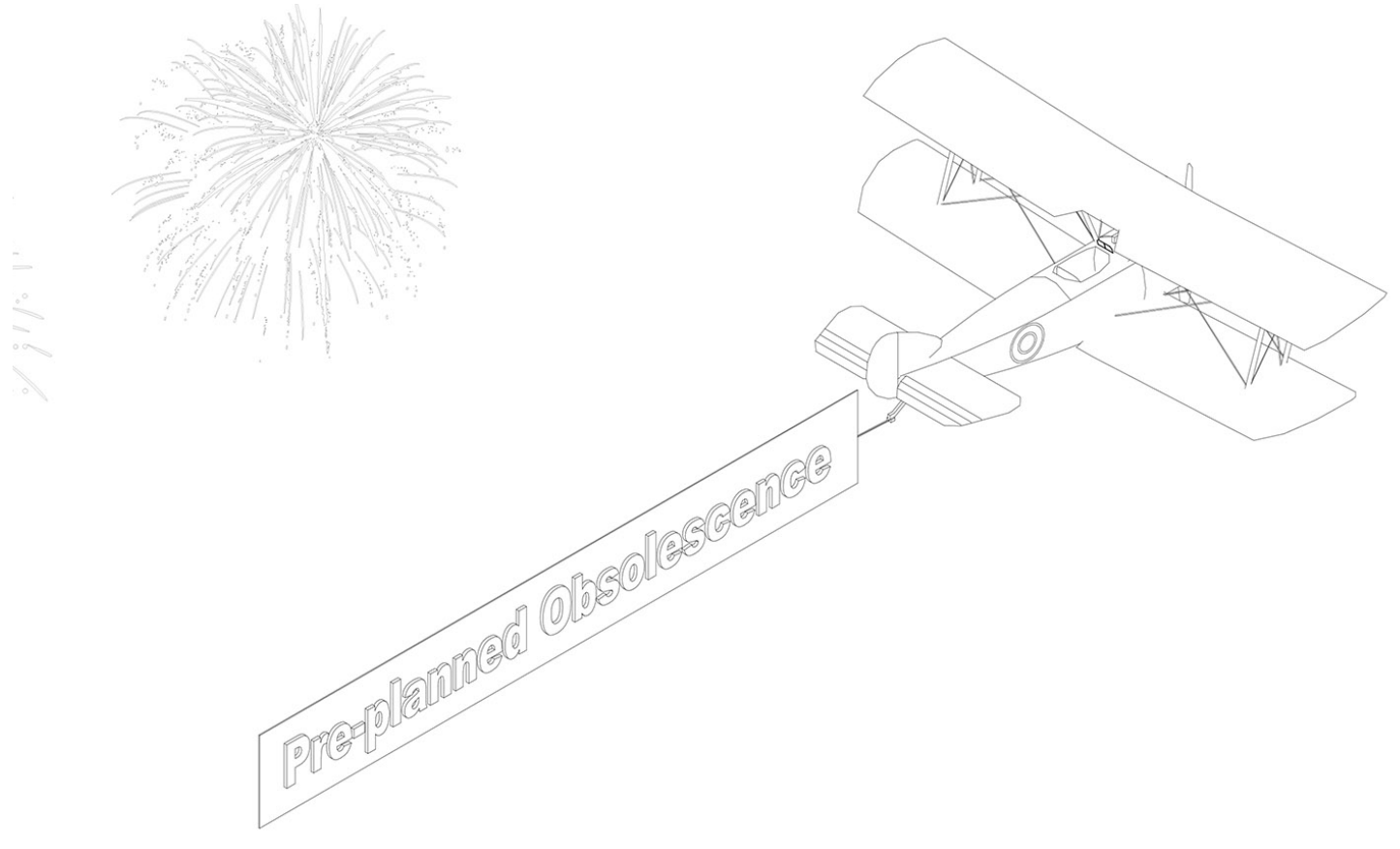

-
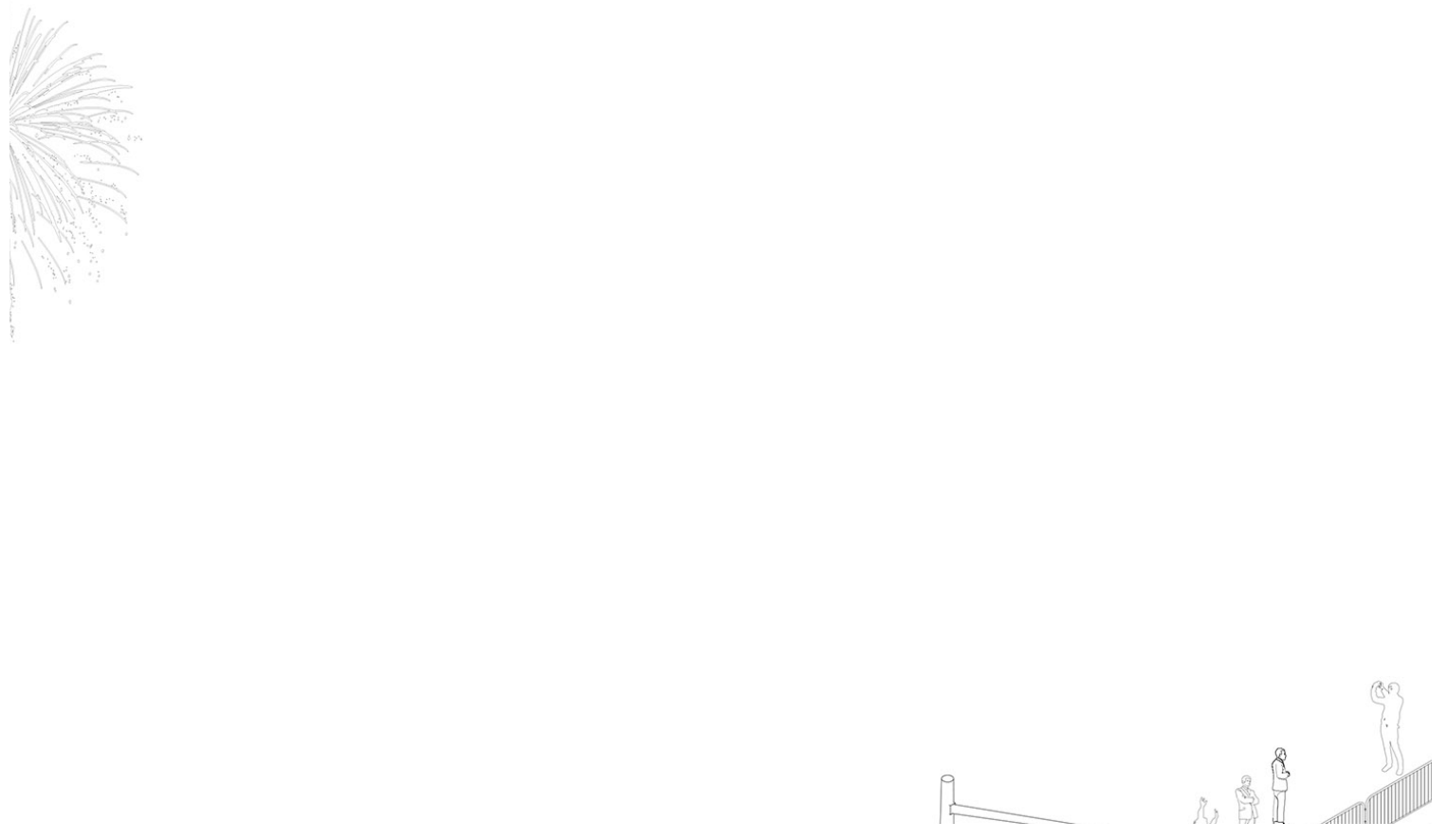


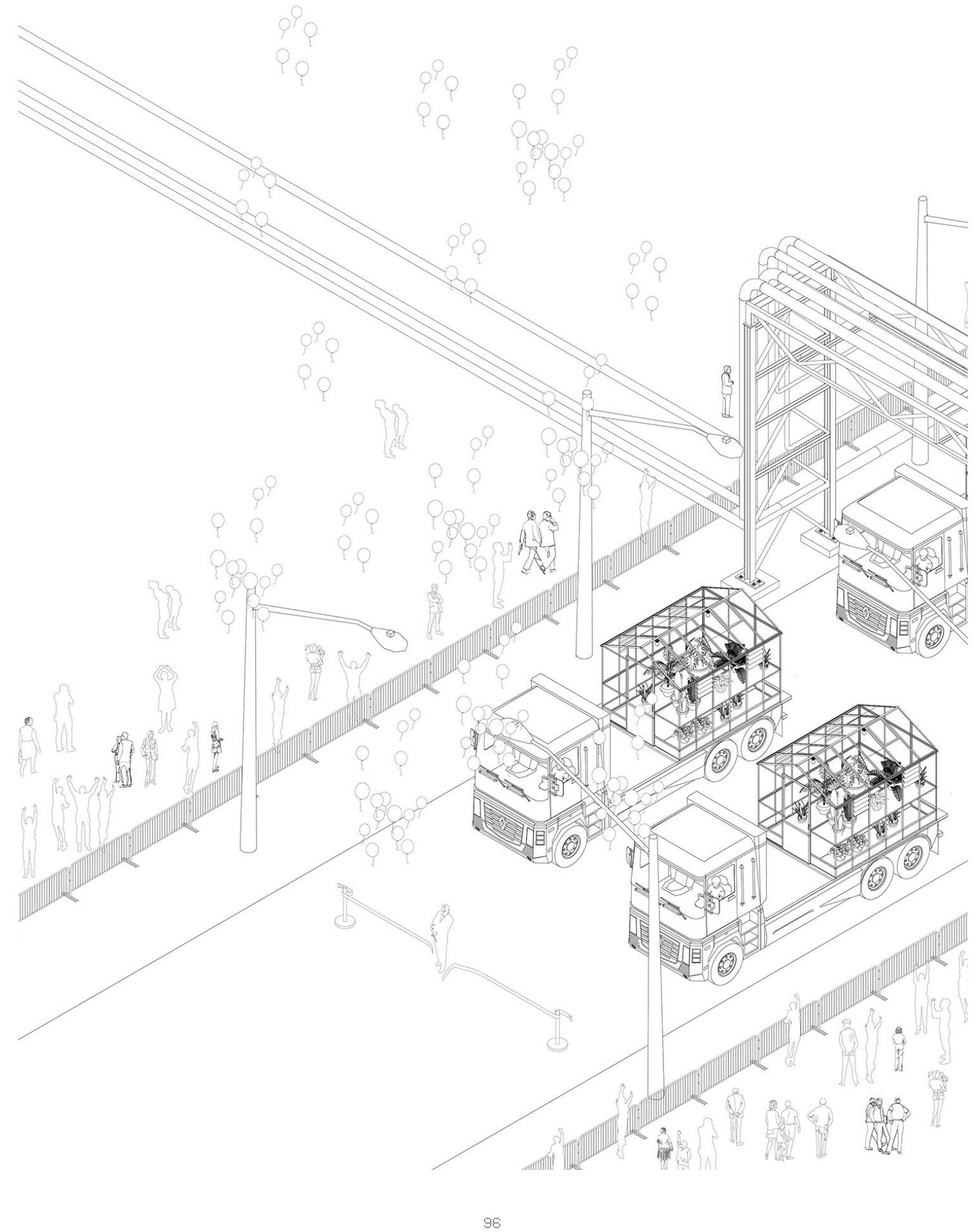




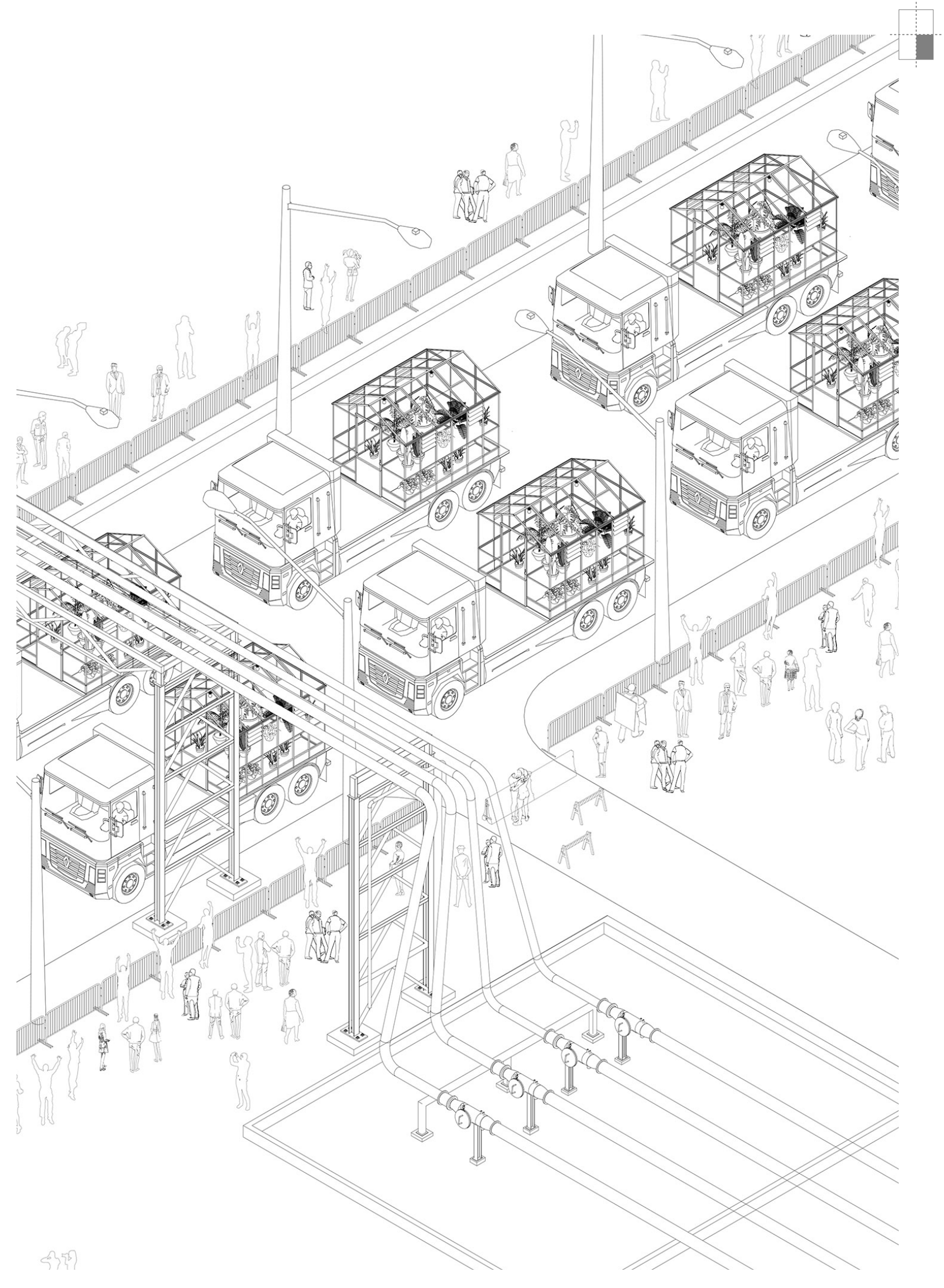




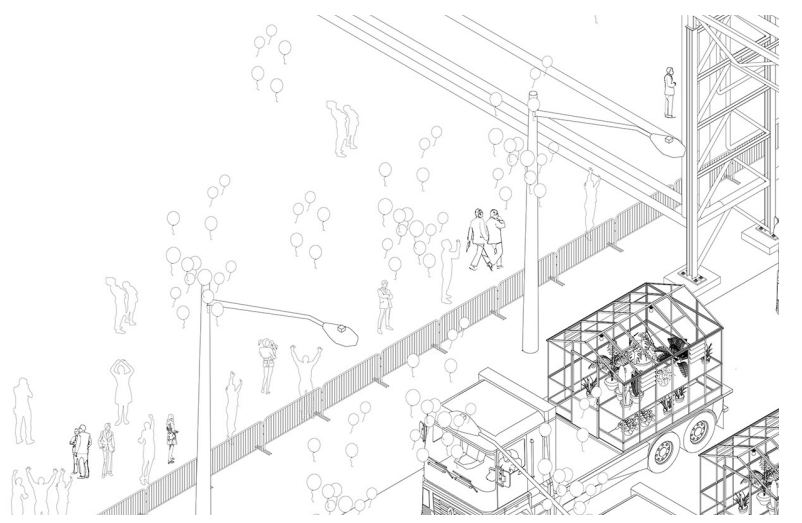


TRANSIENT WETLANDS TERRITORIES

TYPE 2

ECOLOGISTS

\section{PROJECT: ARCHILOCUS: ALBERTA INSTITUTE OF LAND GENERATION}

TWTs are infused with carbon to feed microbes in the tailing ponds, which in turn break down hydrocarbons and boost the fine sand settlement process. This is a madly innovative solution to enhance removal of fine particulates from the tailing ponds. TWTs are the only hope to reclaim what was once called land. Once the TWTs set sail, the shallow vegetation on the surface of the floating basin provides enough area and nutrition to support various species of birds and mammals. This Archilocus is the new Alberta tourist destination to rival the Rocky Mountain range.

Text Inspired by Oil Sand 2.0

Hong Kong is Land

Map Office

Gutierrez, Laurent, and Portefaix, Valérie. Hong Kong Is Land,

SAN ROCCO. ECOLOGY, October 1, 2014. 156. 


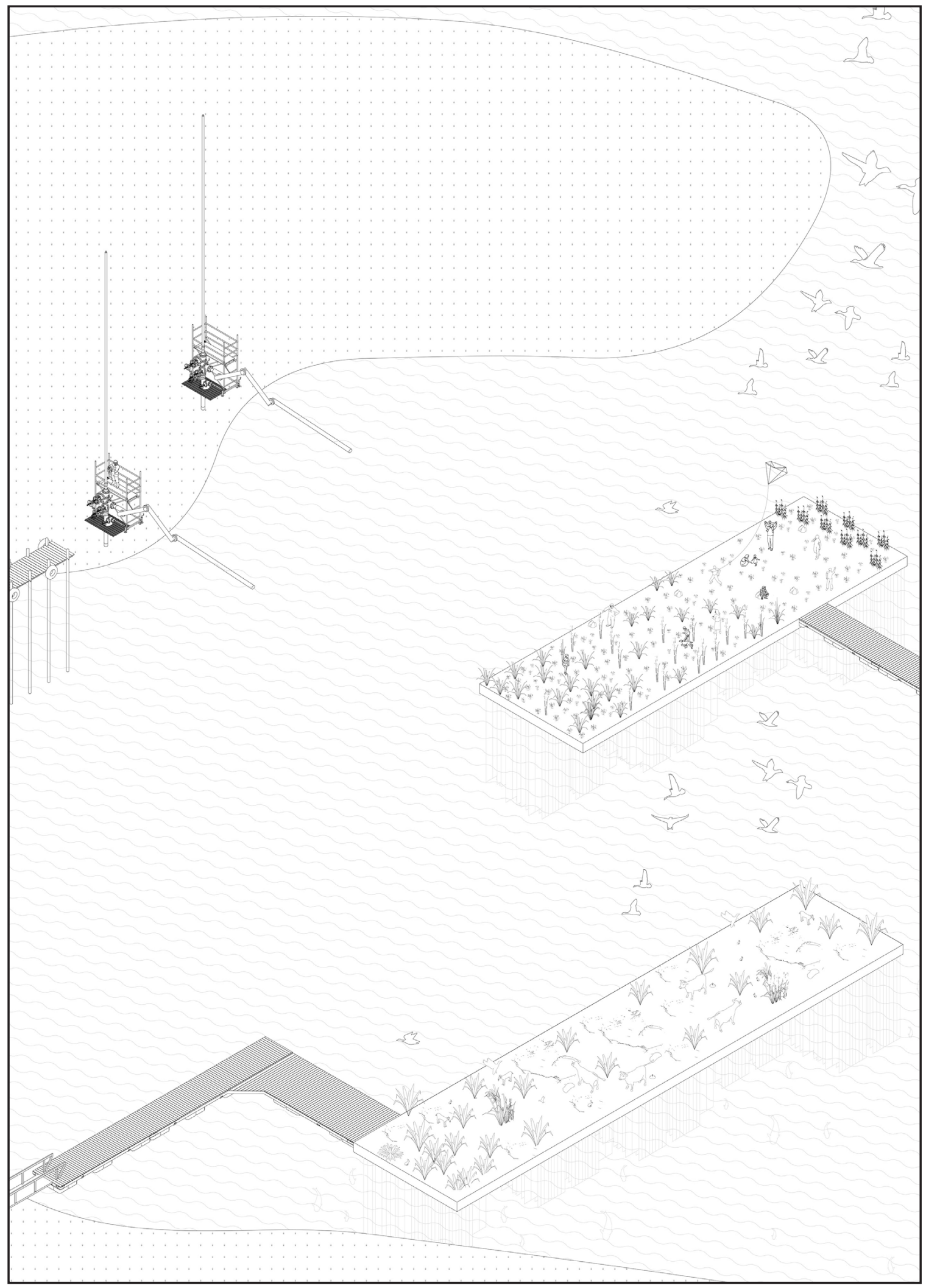




\section{TRANSIENT WETLANDS TERRITORIES}

Freshwater resources in many parts of Alberta were increasingly overused and thus exhausted. By 2025, the highly polluted wastewater (tailing ponds) from the Oil Sand industry had saturated most of the northern part of Alberta. By 2030, the Athabasca River, Alberta's main water source had been completely contaminated due to multiple pipeline accidents. The treatment of polluted water and its reuse possibilities were the region's top priority. The importance of water treatment let to the establishment of the Alberta Institute of Land Regeneration (AILR).

On January 17, 2037, AlLR issued an emergency action plan. The plan's main objective was to transform highly polluted wastewater into water of varying quality, and in some areas into drinking water. Thus, Transient Wetlands Territories (TWTs) were constructed. A TWT is an artificial wetland created for the purpose of handling anthropogenic discharge created for land reclamation and tailing pond recovery.

The primary impetus behind TWT invention was the 2020 economic crisis and the desperation for clean land. TWTs are floating wetlands, "biological supermarkets; they are of special ecological importance since they are among the most productive natural environments in the region and support a wide diversity of species. 
TWTs function as deep dyke cleaning systems consisting of rectangular soil basins with synthetic textile curtains. These curtains are infused with carbon to feed microbes in the tailing ponds, which in turn break down hydrocarbons and boost the fine sand settlement process. This is a madly innovative solution to enhance removal of fine particulates from the tailing ponds. TWTs are the only hope to reclaim what was once called land.

Once the TWTs set sail, the shallow vegetation on the surface of the floating basin provides enough area and nutrition to support various species of birds and mammals. This Archilocus is the new Alberta tourist destination to rival the Rocky Mountain range. 


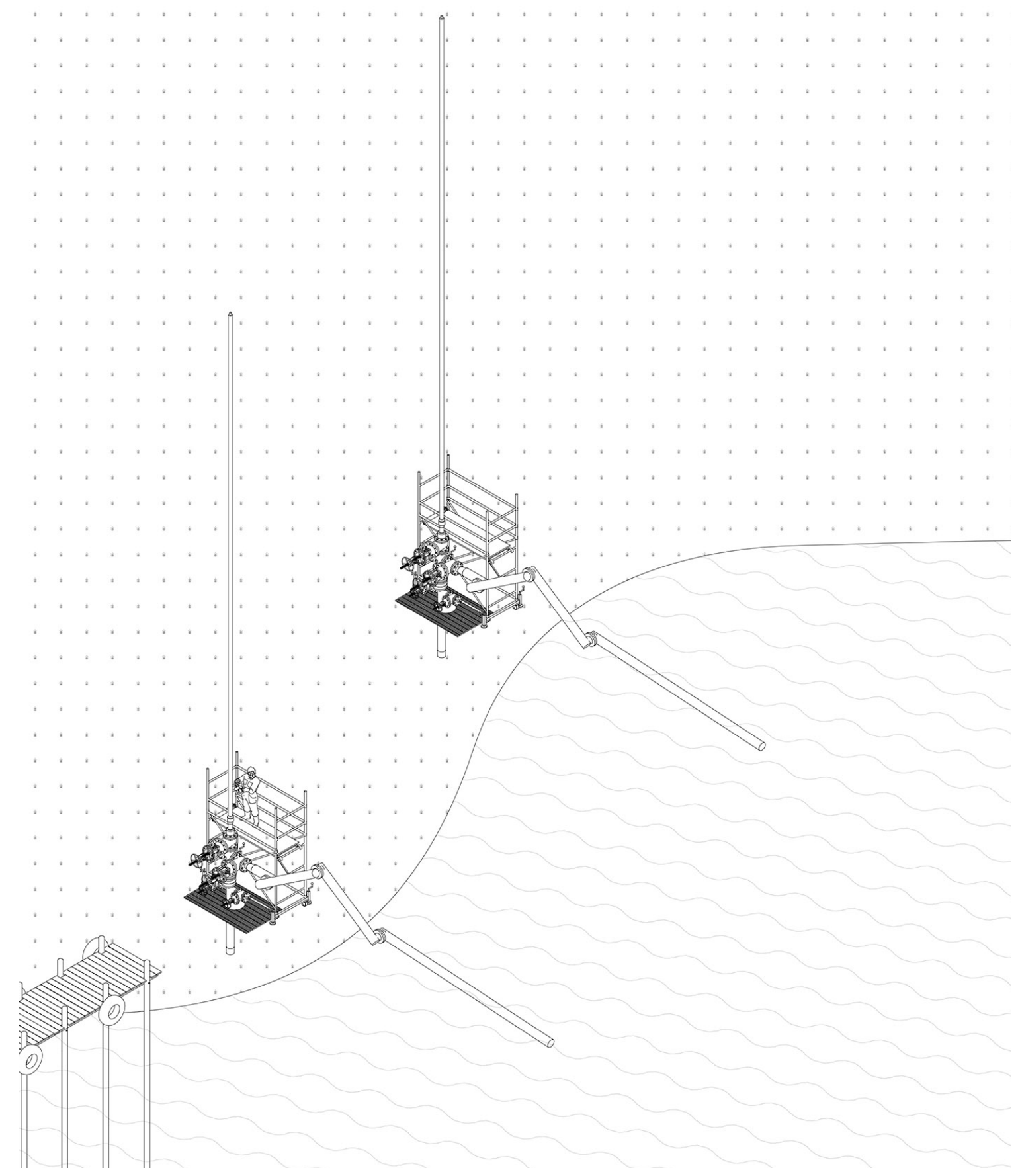




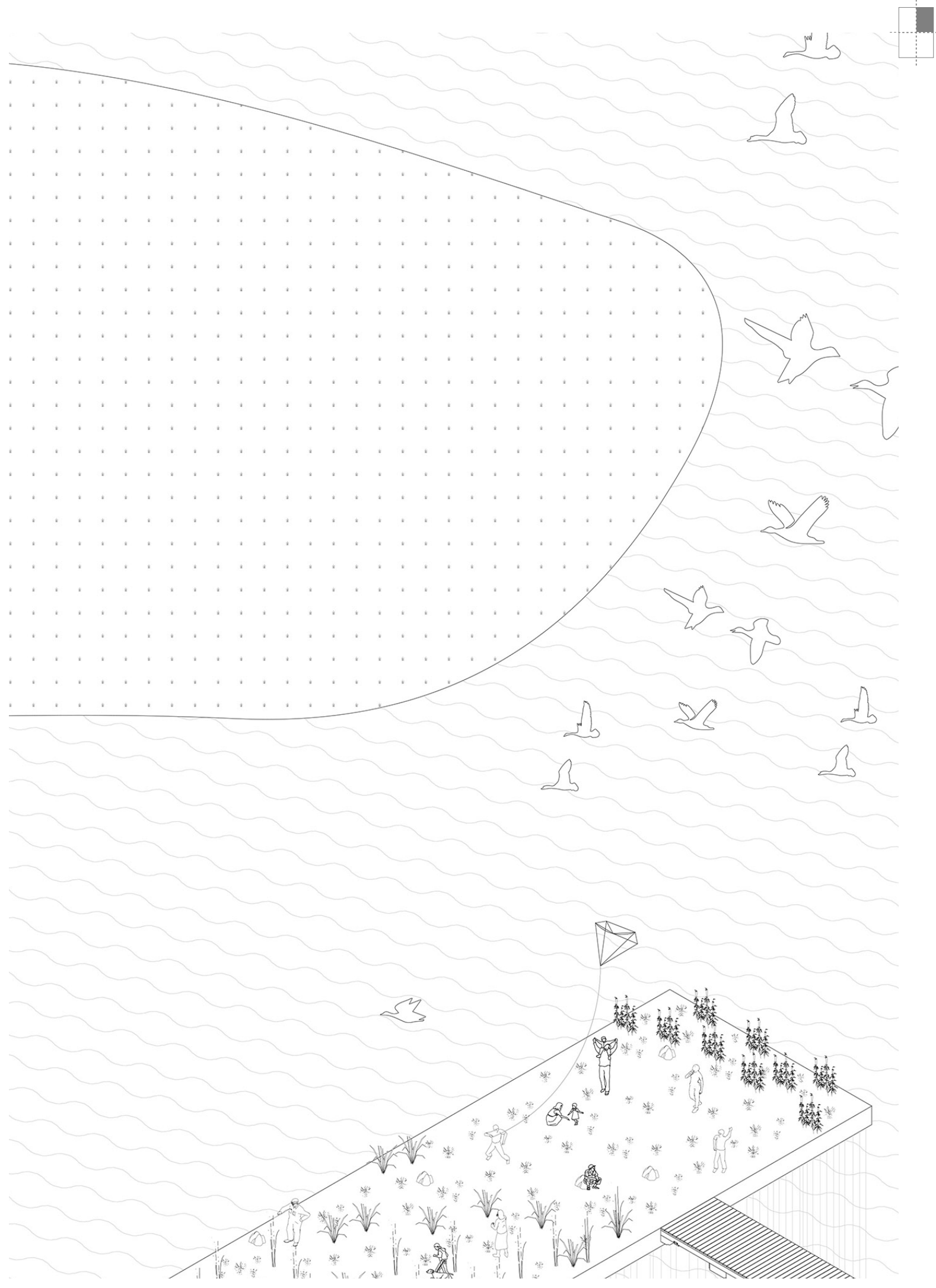


$\|$ HW

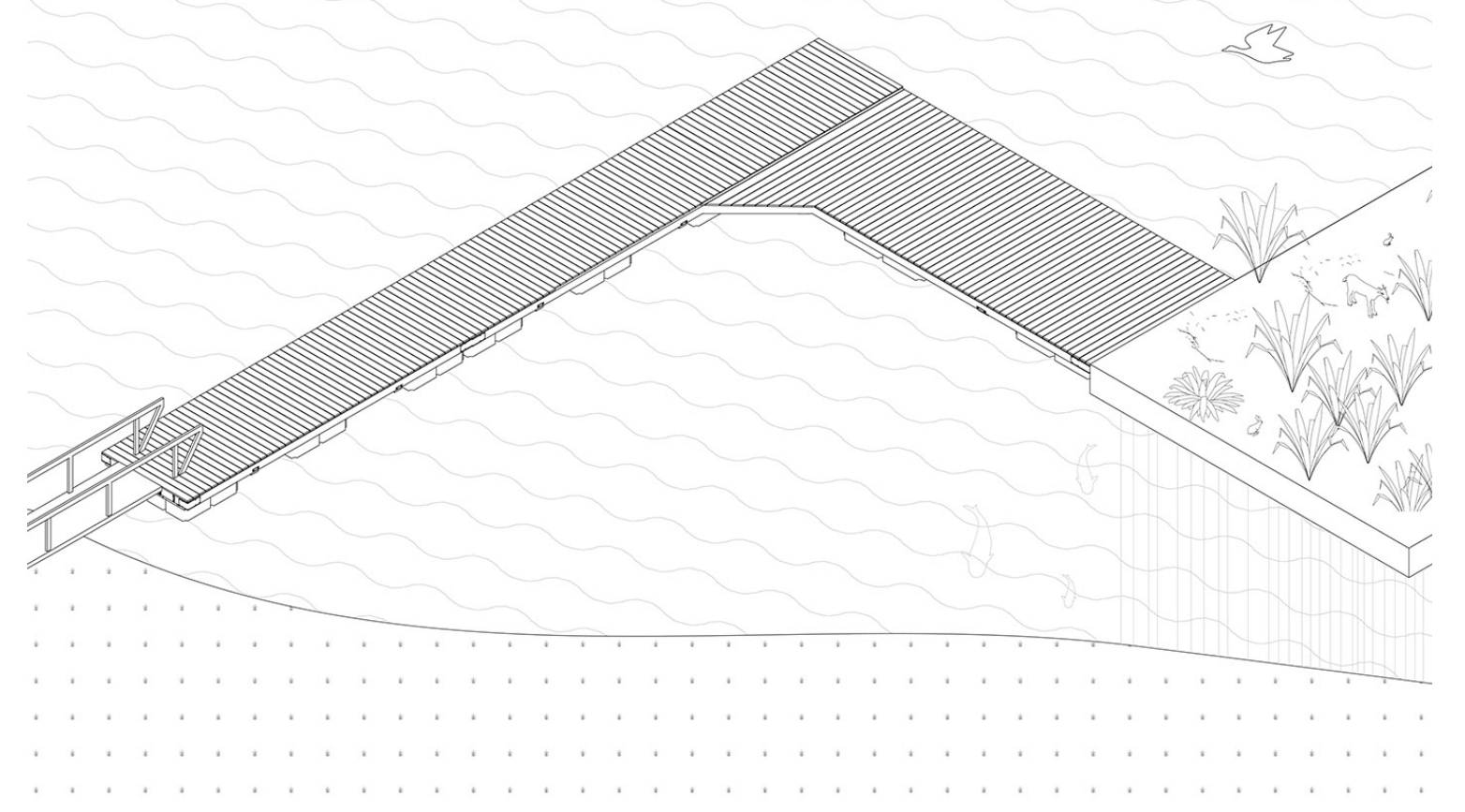




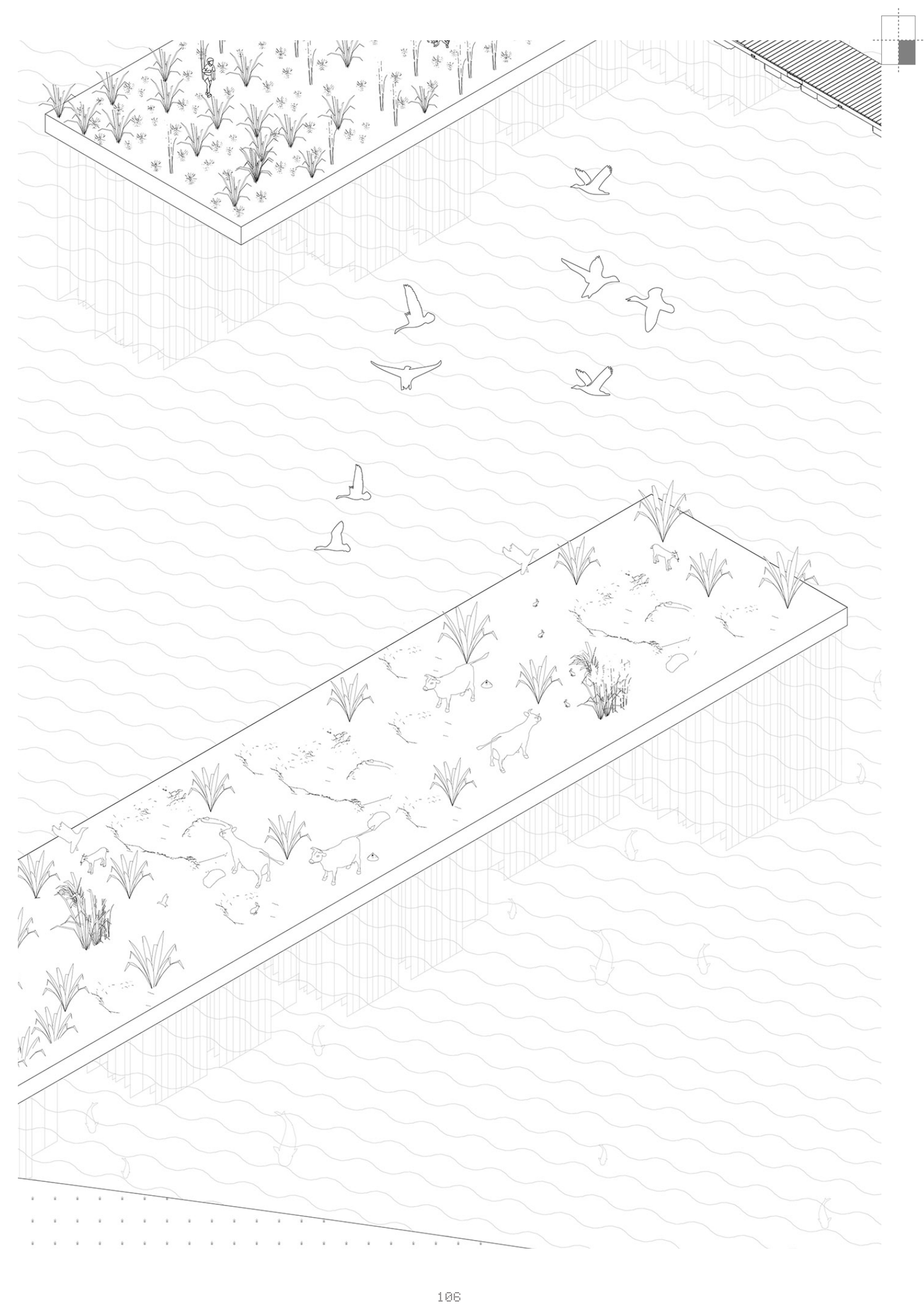




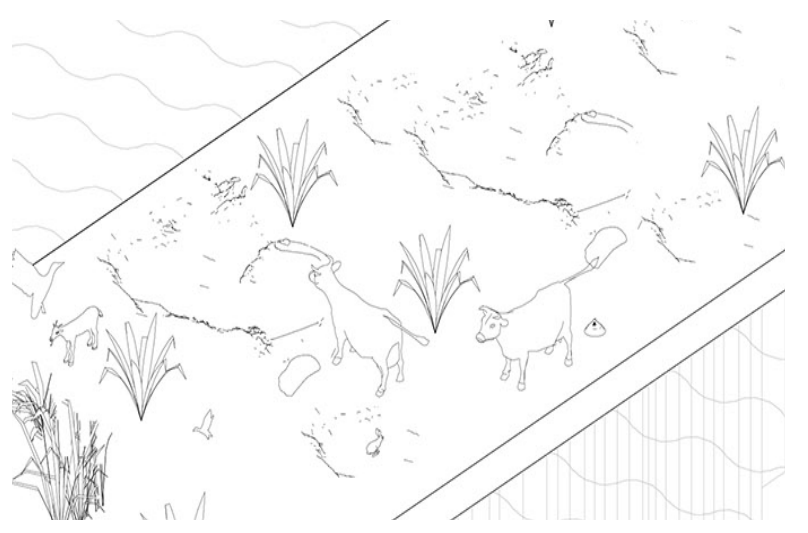




\section{NEW ALLIANCE TERRITORY}

TYPE 3

POLITICIANS

\section{PROJECT: FAÇADESCAPE}

By 2055, the New Alliance Territory had been effectively transformed into a state of disuse. The oil industries CAT walks is now populated with façades that represent various political parties that have cleansed the contaminated landscape of the oil and gas industries from 2016. The lucrative political campaign process of remediation is exhibited by department of factual certainty as a symphony of façades that has re-mediated and transformed the landscape into a performance of truth, reality and personality contest. The parties' banners and flags move in unison to broadcast their presence in the field and reach out to their constituency for support.

Text Inspired by

Made In Australia: The Future Of Australian Cities

Richard Weller \& Julian Bolleter

Published in Scenario 03: Rethinking Infrastructure, spring 2013. 


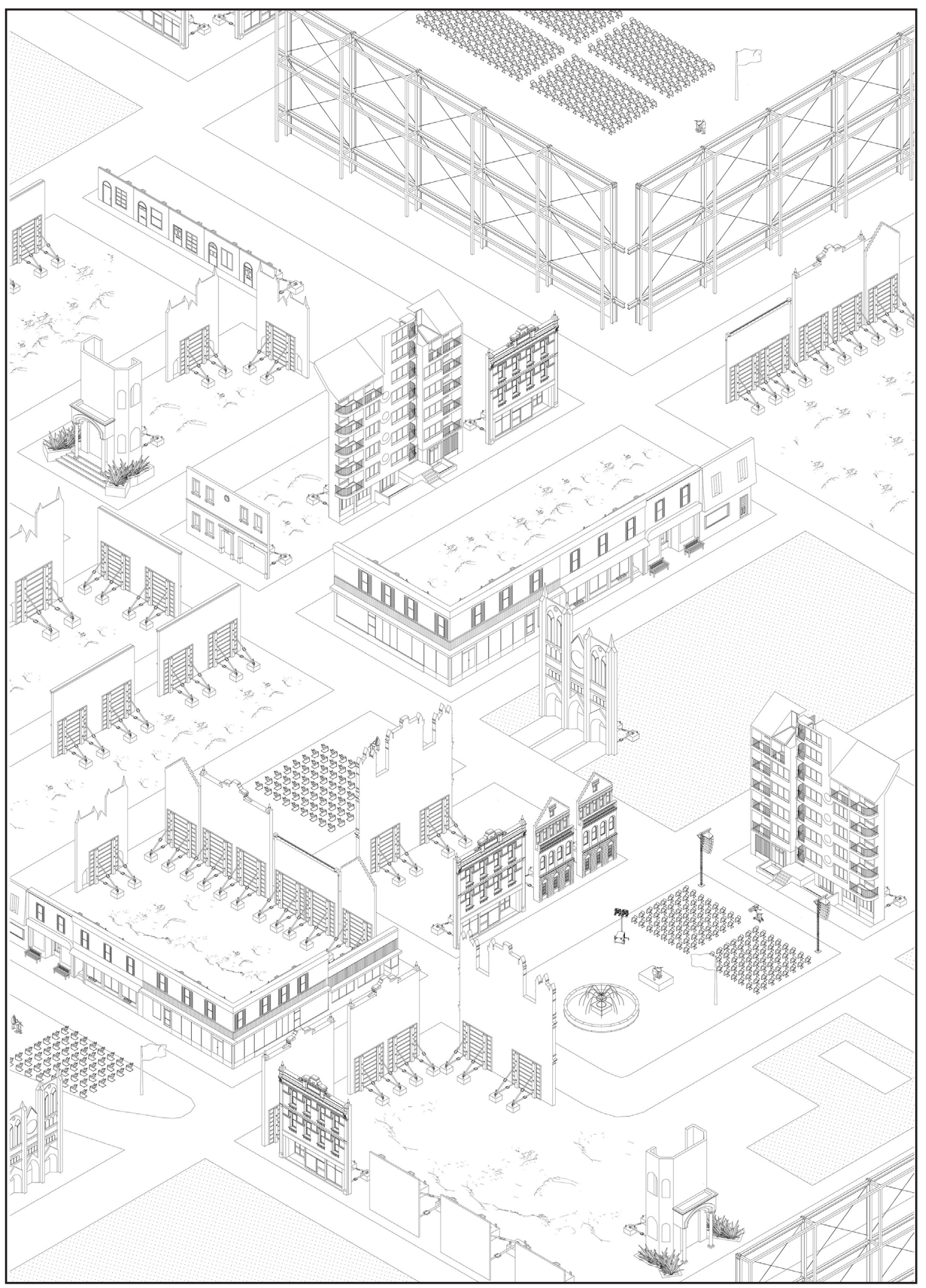




\section{NEW ALLIANCE TERRITORY}

As the Oil Sand industry finally began to reveal its true face in September 2015, it became embarrassingly clear that the industry was faced with a stark choice: shutdown or responsibility. By 2055, the New Alliance Territory had been effectively transformed into a state of disuse. The oil industries CAT walks is now populated with façades that represent various political parties that have cleansed the contaminated landscape of the oil and gas industries from 2016.

The lucrative political campaign process of remediation is exhibited by department of factual certainty as a symphony of façades that has remediated and transformed the landscape into a performance of truth, a reality and personality contest. The parties' banners and flags move in unison to broadcast their presence in the field and reach out to their constituency for support.

Coordinated and governed by the department of factual certainty and city council member Jean-Philippe Šyncrude, this politically informed atmosphere is modelled after a non-figurative fusion of successful cities such as Ottawa and Washington, D.C. 


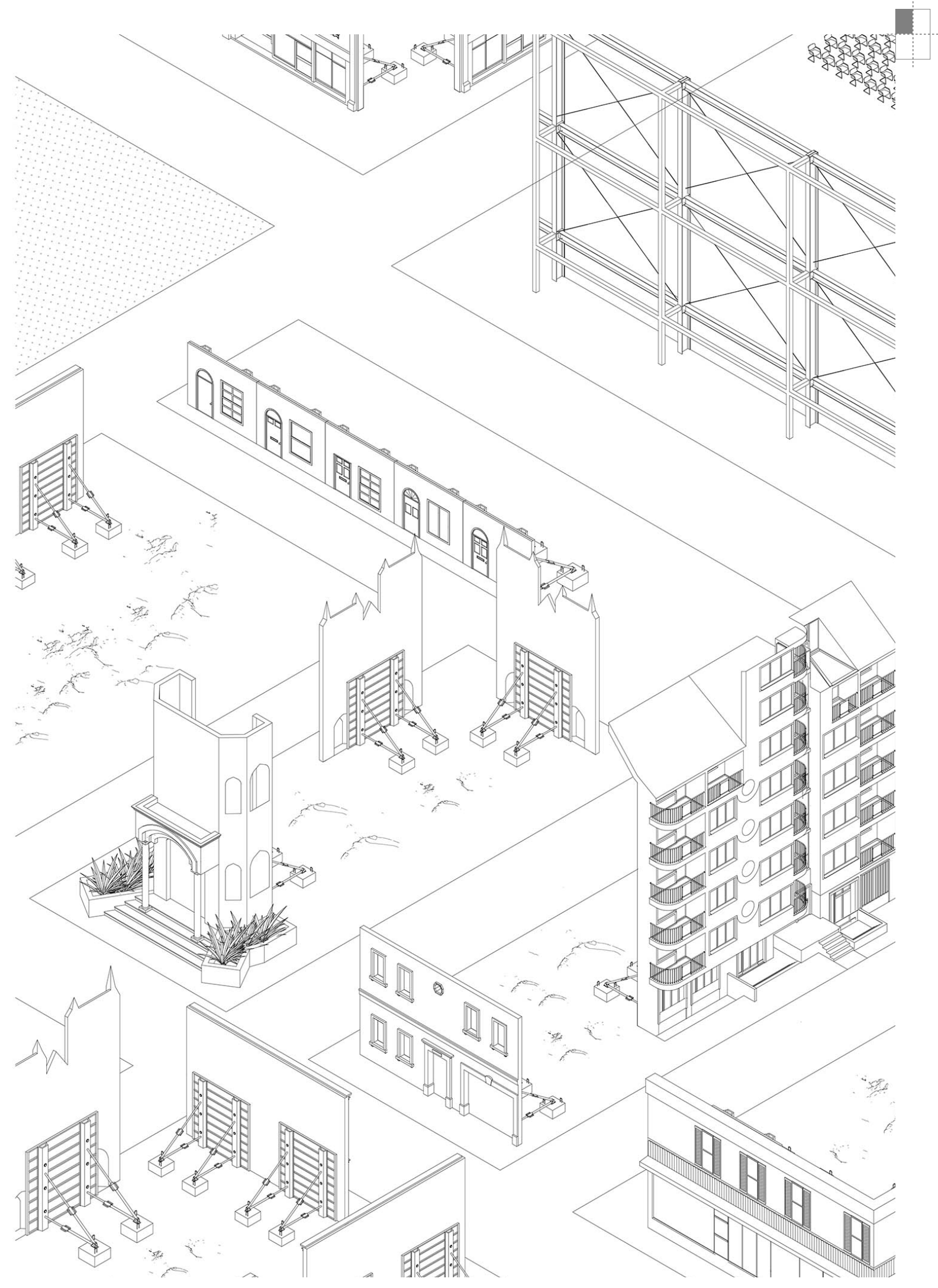




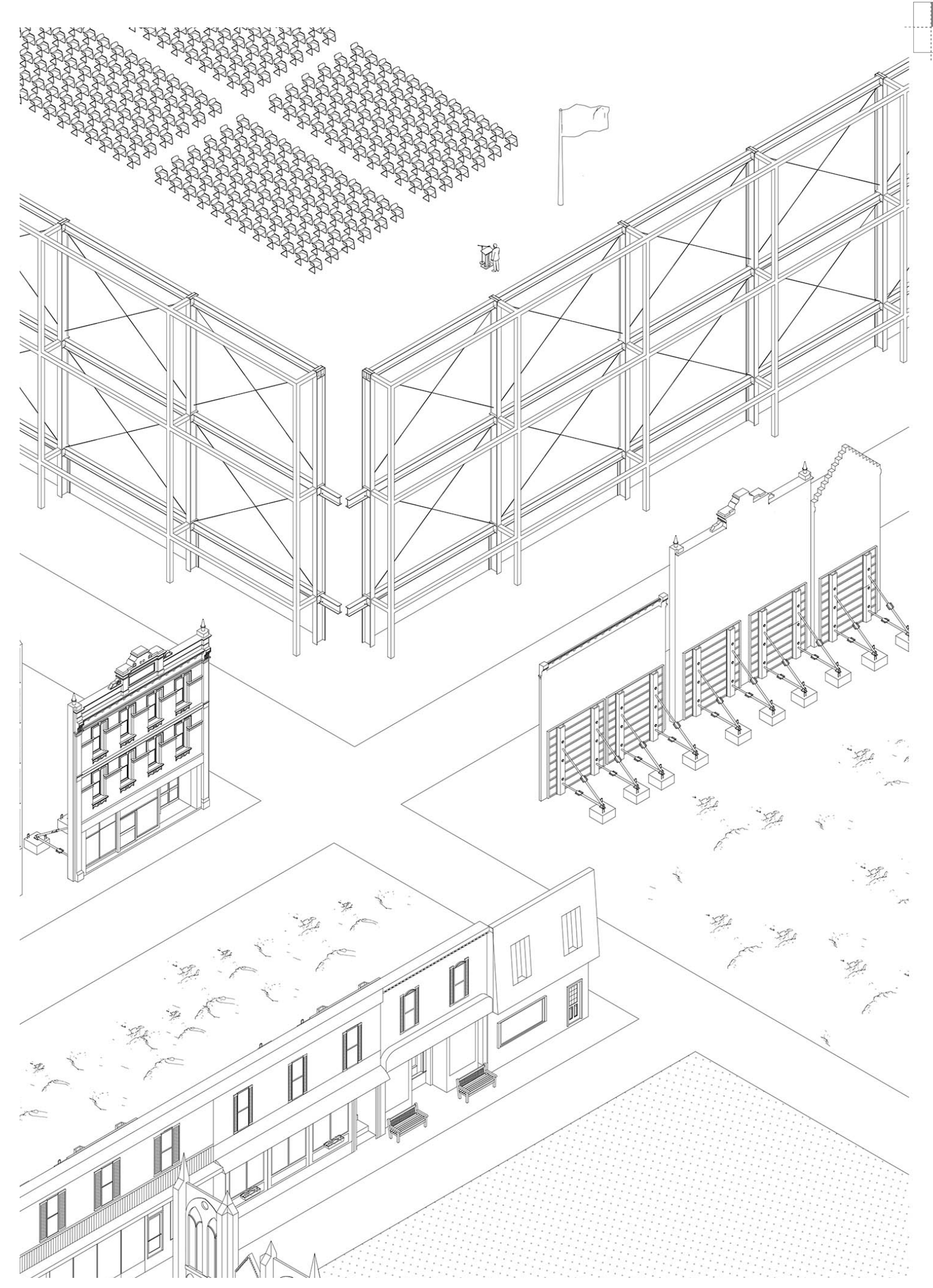




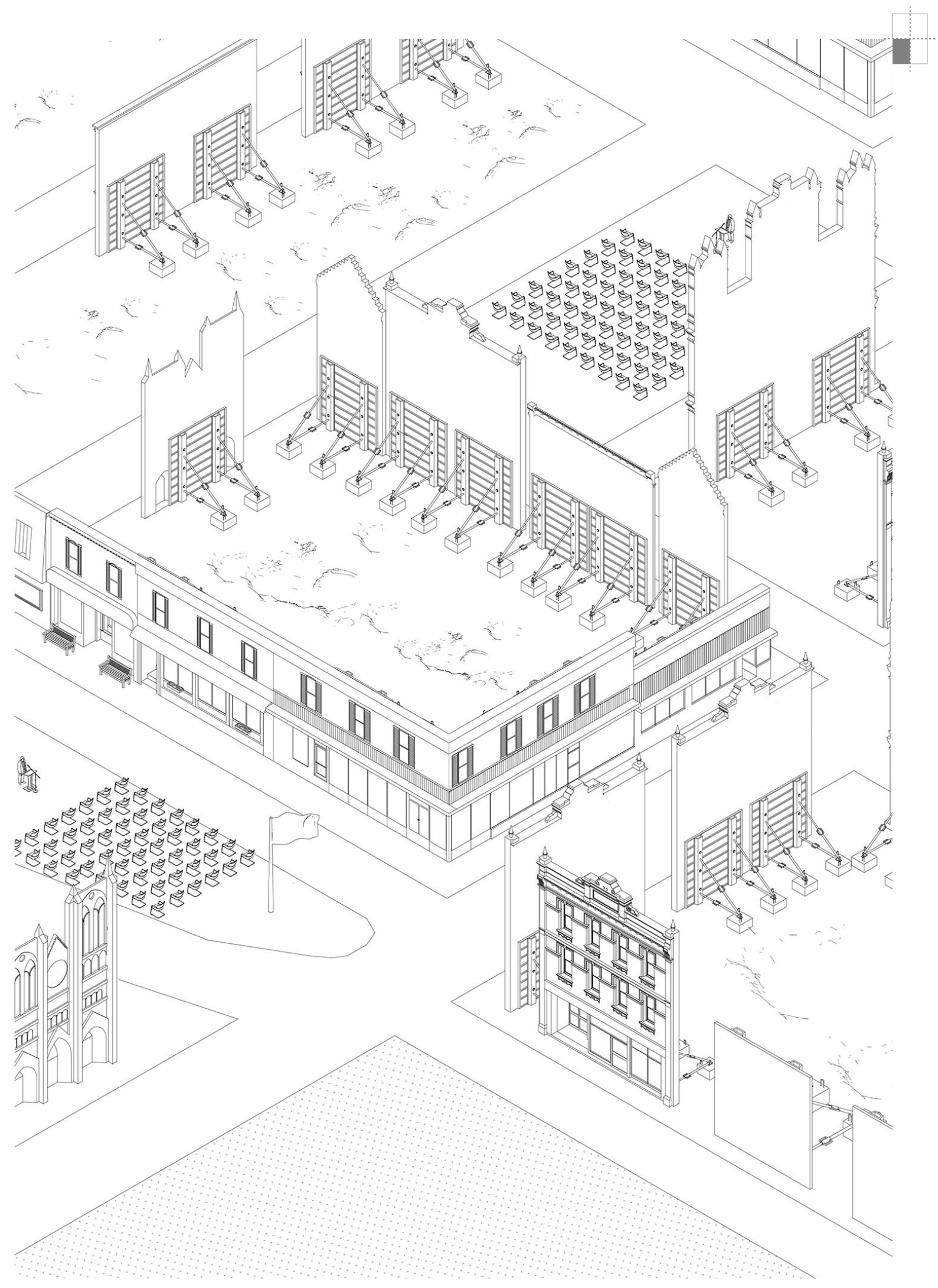




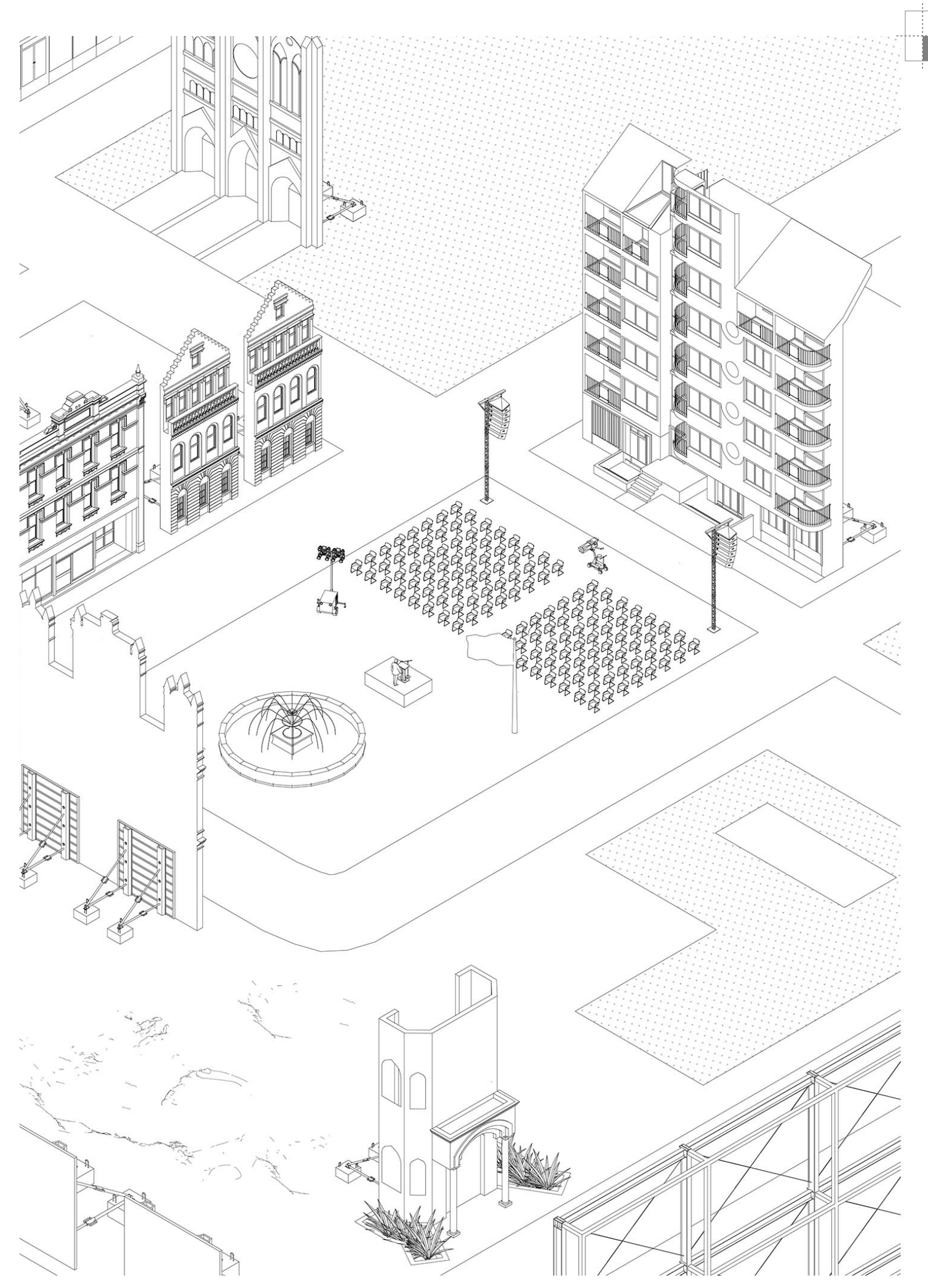




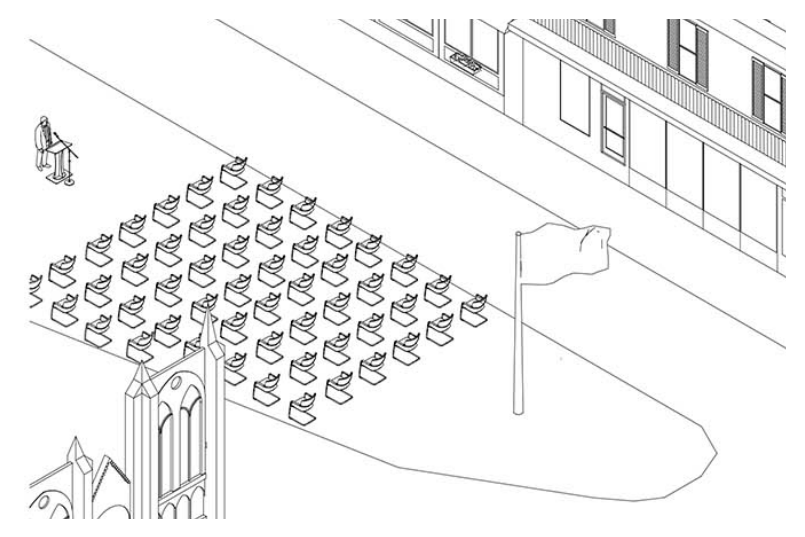




\section{PEDAGOGIC TERRITORY \\ TYPE 4 \\ DE-SCHOOLING APPARATUS}

\section{PROJECT: MERCENARIES OF ARCHITECTURE}

This territory is a unique educational region, rich in diversity, collaboration, and scholarship through design. Here, students explore today's most creative design approaches, with an international faculty prominent across the field. The architecture faculty de-schools each and every student and provides them with a range of design investigations, expands their knowledge, and confronts them with challenges of the contemporary built environment. Upon graduation they will be exported overseas for international markets. Alberta's only means of survival were the Chicago Boys and their new economic theory of tutelage.

Text Inspired by

"The Chicago Boys in Chile: Economic Freedom's Awfull Toll,"

The Nation, Orlando Letelier, August 28, 1976 


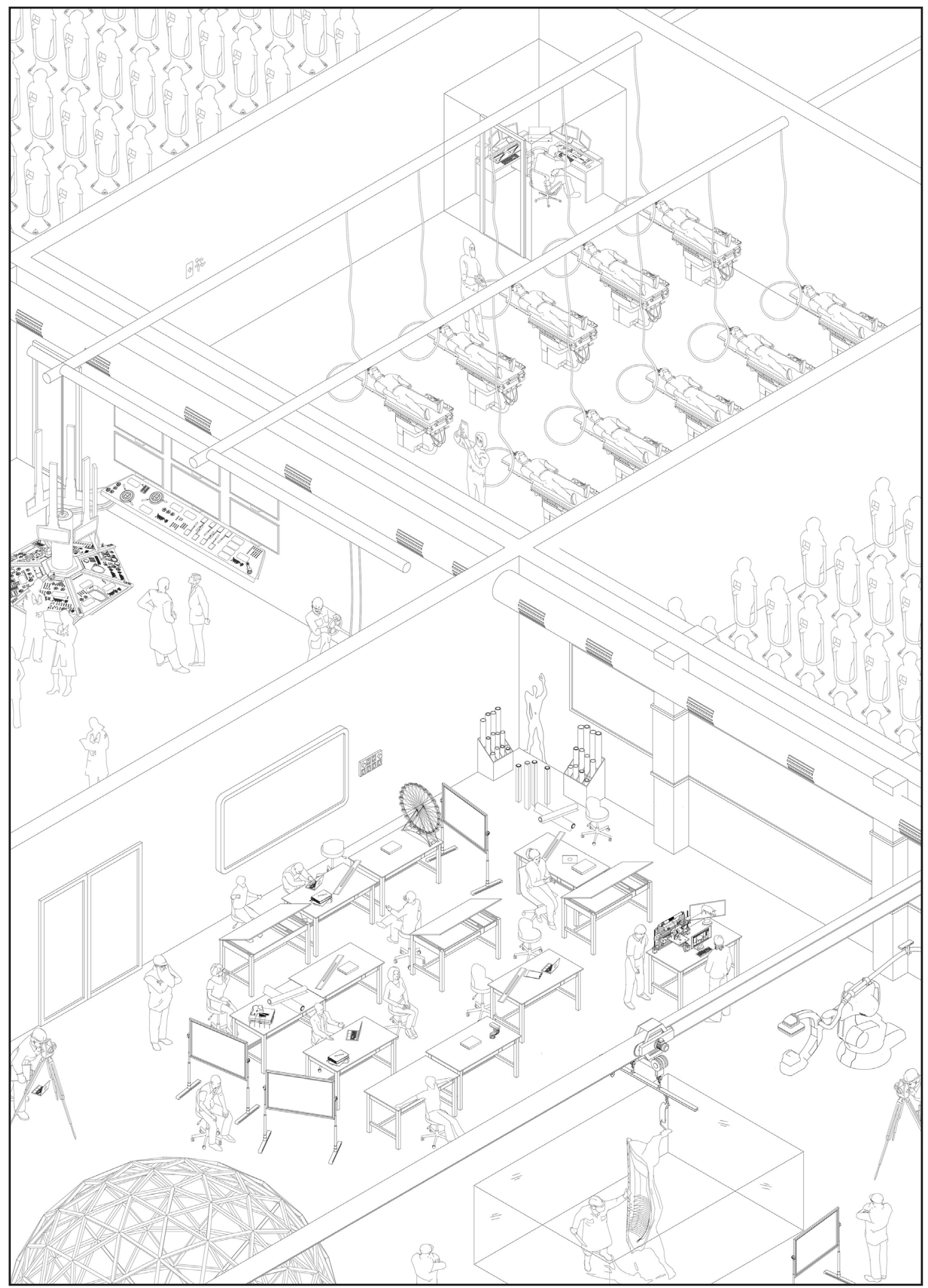




\section{PEDAGOGIC TERRITORY}

In 2017 shortly after the great downfall of the oil industries in Alberta, when inflation still raged and the Persian oil rain triggered a depression in Alberta, Rachel Anne Notley, Premier of Alberta, turned to the "Chicago Boys" and appointed several of them to powerful positions in the government. The Chicago Boys' ideas remained on the fringes of Alberta's economic and political thought, The Chicago Boys prepared a 600-page "Program for Economic Development" called El Arquitecto (the Architect).

New policies were modeled to serve the interests of Academics and Scholars at the expense of Alberta's populations. The highlight of the El Architecto 600-page economic development policies determined that Alberta's energy sector must be eliminated and the region's main objective should be towards education with Art and Architecture at the forefront of the new growth policies.

By 2035 the University of Alberta occupied most of the educational buildings and had built a new campus every $500 \mathrm{Km}$ as suggested by the El Architecto's manifesto. This new pedagogic territory emerged from the ruins of the old-oil. Originally staged for an insurance scam by bankrupt oil investors, it was never intended to be resurrected as one of the most profitable regions of the new North. 
The Pedagogic Territory of Alberta is a unique educational region, rich in diversity, collaboration, and scholarship through design. In this new territory, students explore today's most creative design approaches, with an international faculty prominent across the field. Students in Alberta are integrated into an active network of internationally recognized designers, dedicated to addressing the changing needs of the modern world.

Together with visiting design critics and theorists from around the world, the architecture faculty de-schools and dehumanises each and every student and provides them with a range of design investigations, expands their knowledge, and confronts them with challenges of the contemporary built environment. Upon graduation they will be exported overseas for international markets. Alberta's only means of survival were the Chicago Boys and their new economic theory of tutelage. 


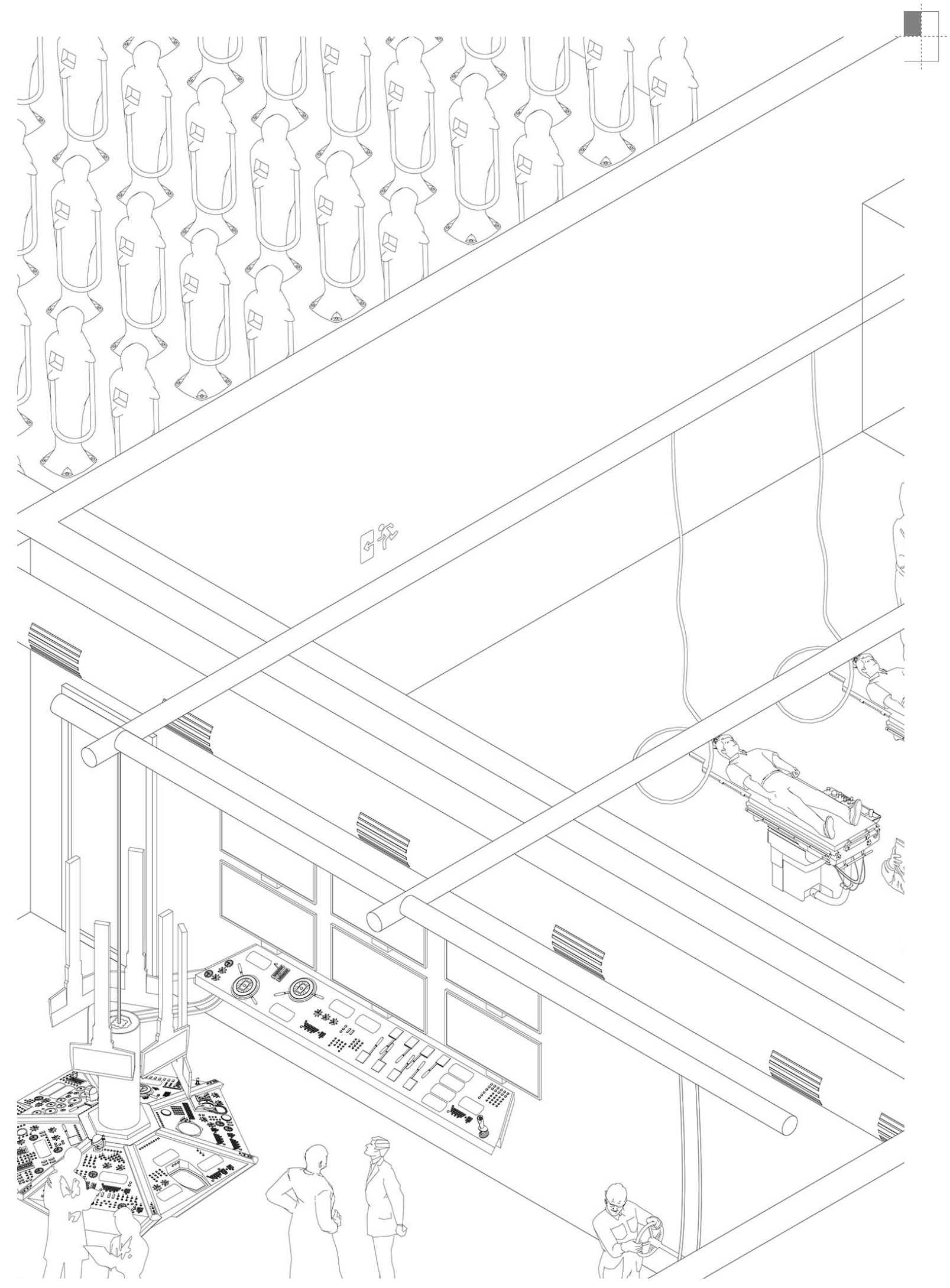




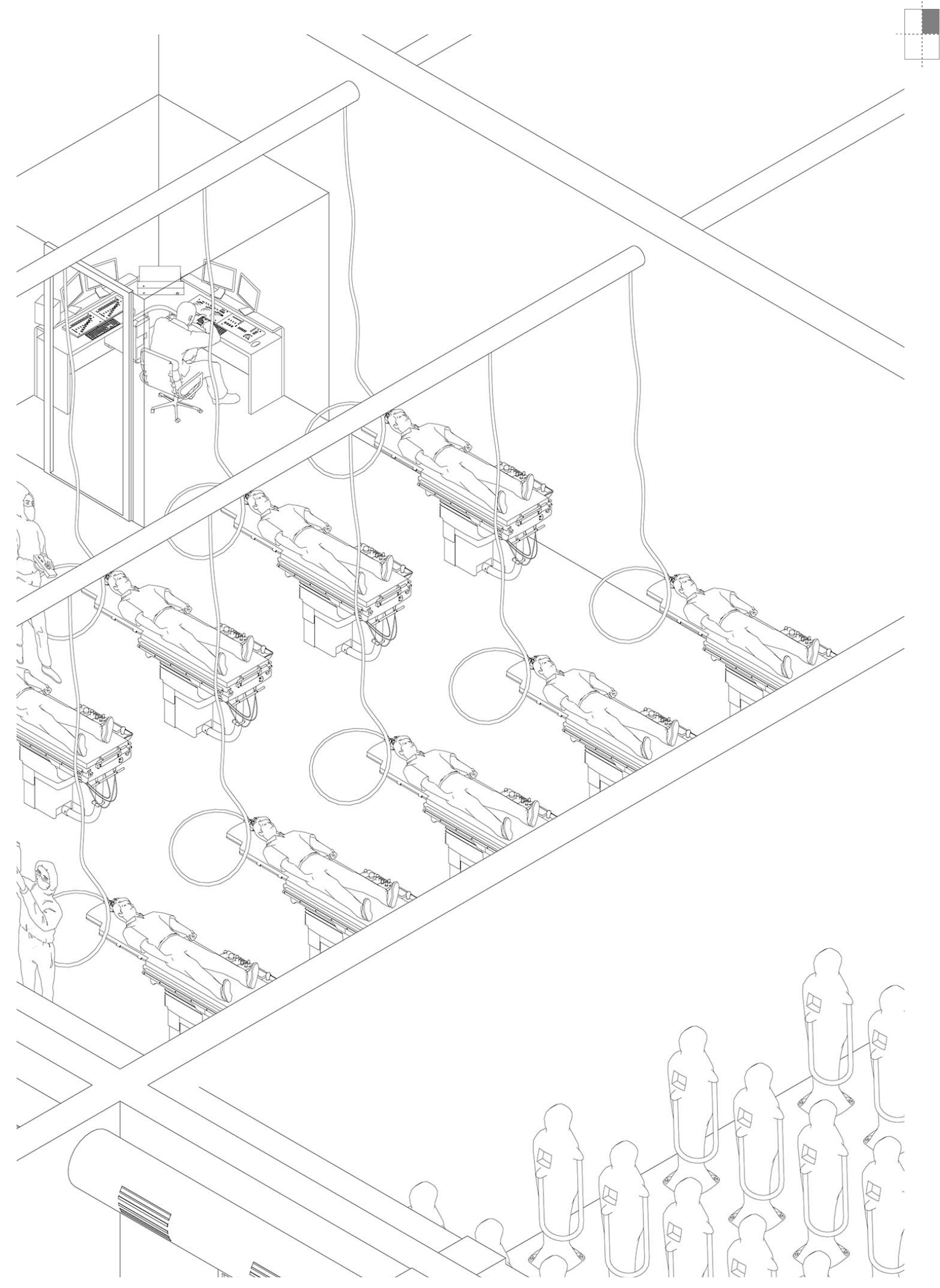



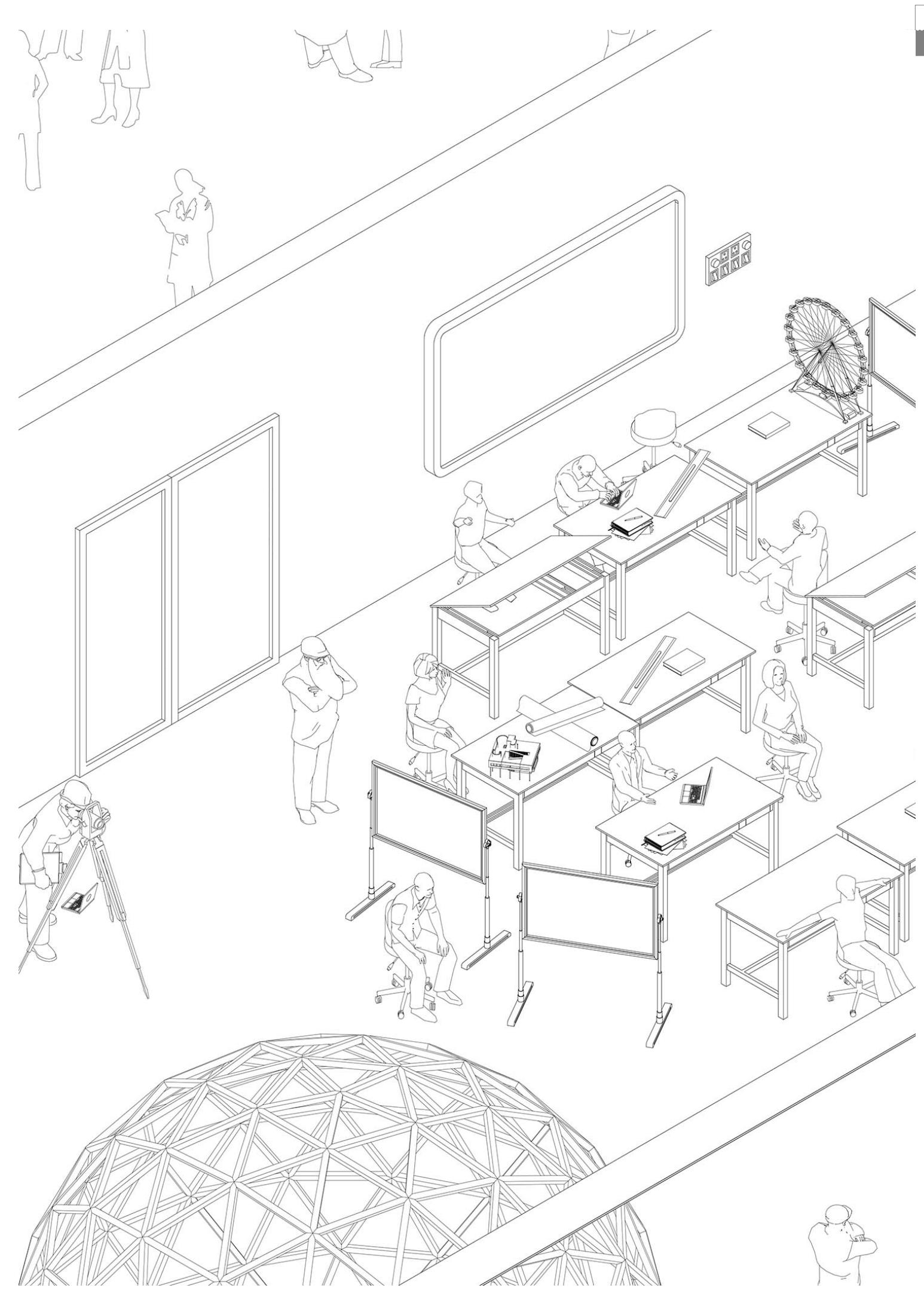


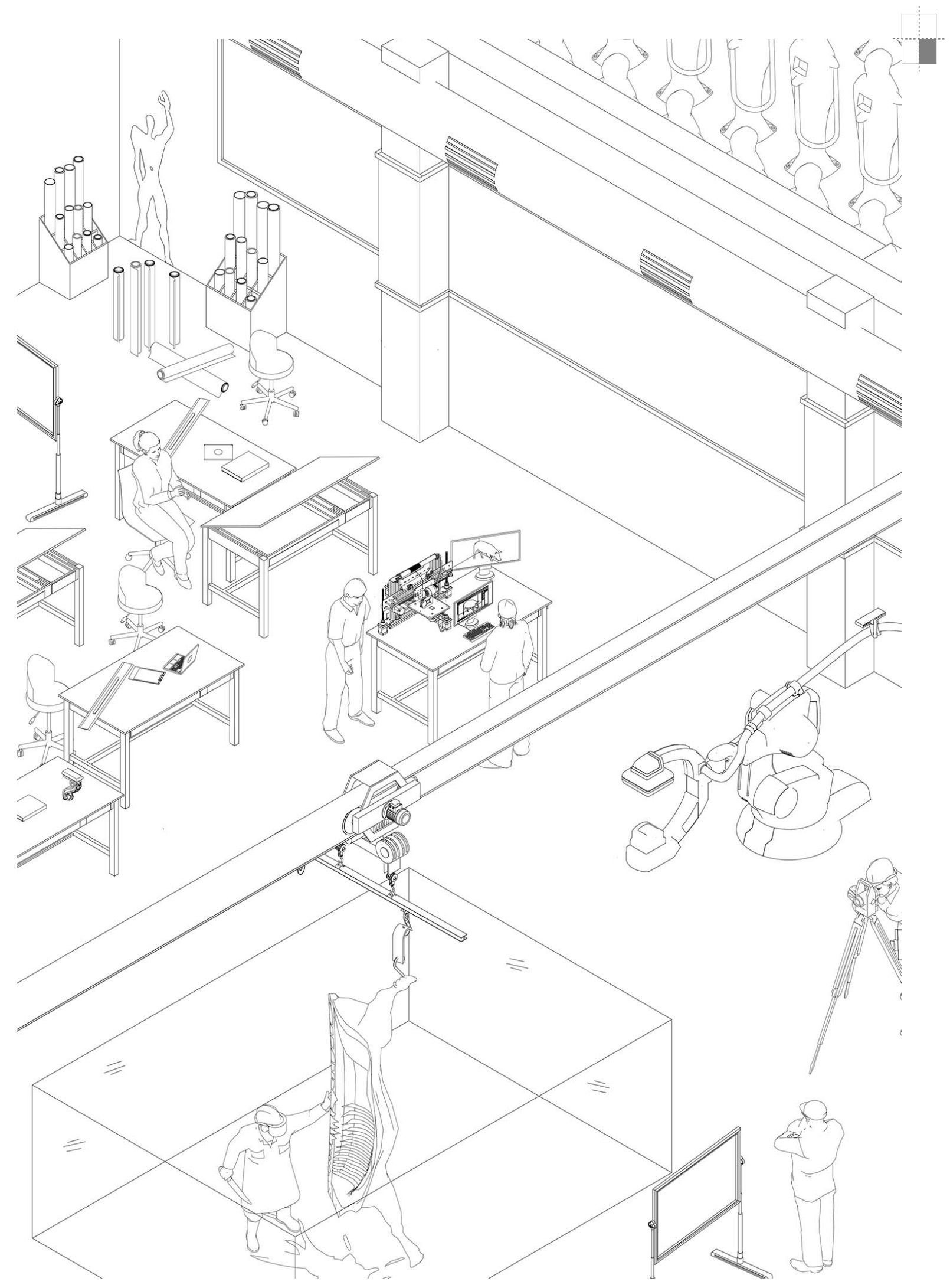




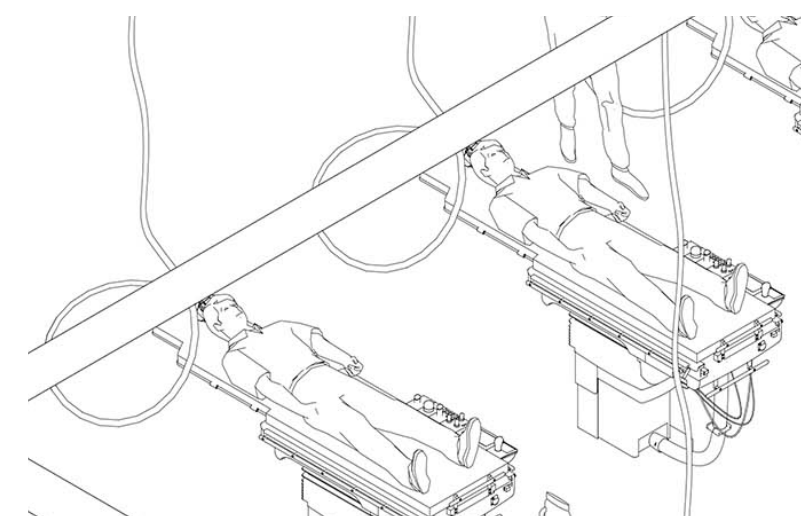




\section{BUREAU OF RECLAMATION}

TYPE 5

STEP-MOTHER NATURE

\section{PROJECT: SPACE FRAME FARMING}

Here in Fort McVegan, all that is left over is converted to feed cows. Cows are employed for casual strolls in hä-häs. Fresh manure produced by cows are sent to nearby digestion chambers to produce biogas that fuels the city and connects every BBQ restaurant with a biogas piping system. This new territory can coexist with living spaces, promoting a return to the Deutscher Werkbund model of 19th century Germany, henceforth promoting the Homo Faber movement with the agricultural city' as the result, a genuinely mixed-use fruitful place with an identity.

\footnotetext{
Text Inspired by

Harnessing the Hidden Power of Cow Manure

Sarah Sanborn

AUG. 29, 2013, see http://ww2.kqed.org/quest/2013/08/29/

harnessing-the-hidden-power-of-cow-manure
} 


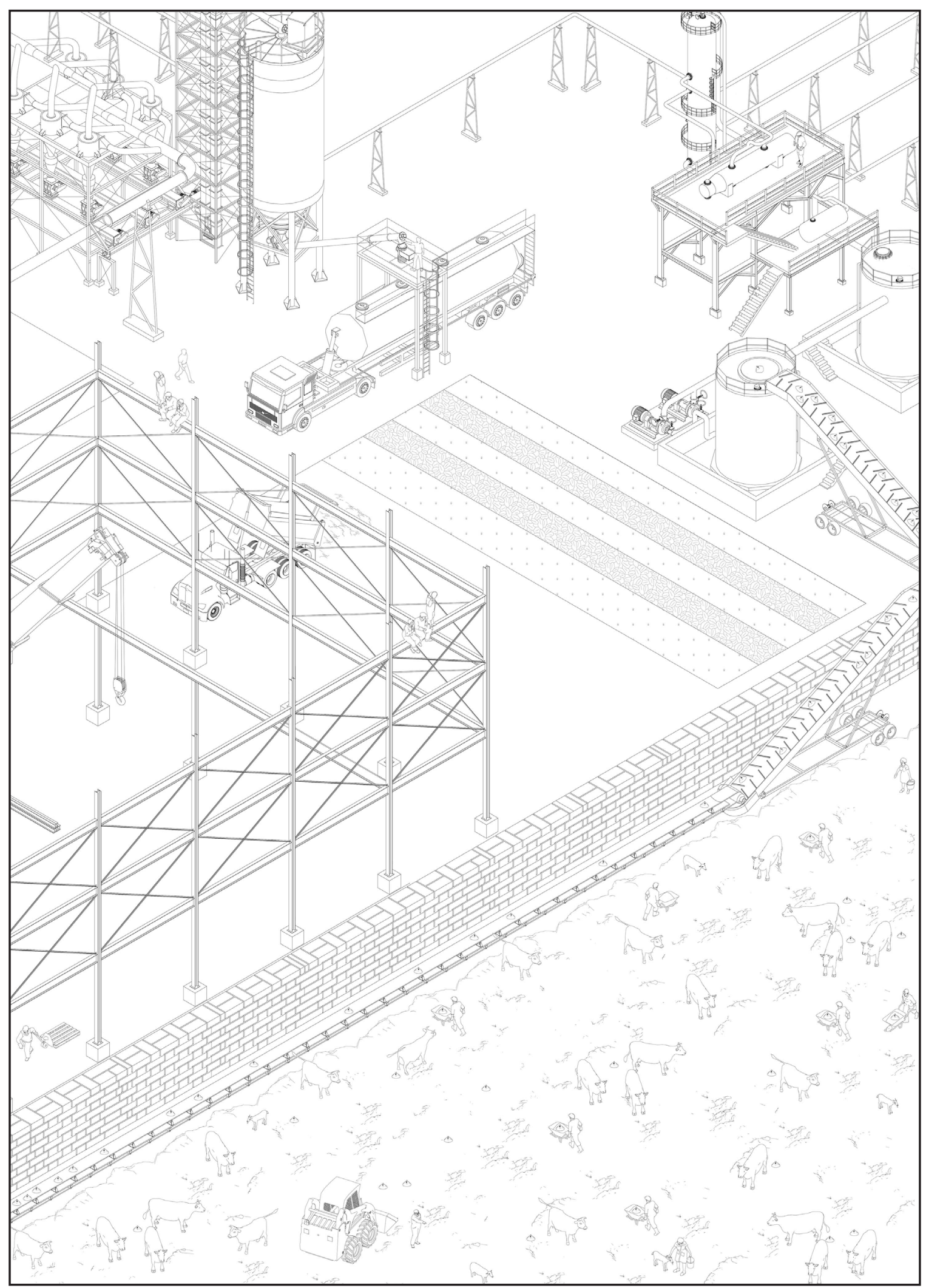




\section{BUREAU OF RECLAMATION}

Fort McVegan is a new territory built as a catalyst for a self-sustaining, free-range farming and tackles the region's over-reliance on imported food. Fort McVegan has completely eradicated unemployment, oppressive marginalization, loneliness, boredom, anxiety and neurosis. Alberta no longer relies on the foreign worker program, and the regions net immigration has increased to 250 per 1,000 persons (based on midyear population). In other words since 2020 Alberta's population has grown form 4.146 million to 5.2 million.

Fort McVegan, the new sunshine conurbation, led the way through mobile computing, mini-chromosome technology, nitrogen utilization, telematics and hyper precision in the agricultural industries and its existing vast landscapes.

The Advanced lightweight space frame structure technologies throughout the early part of the 21st century - popup industries, 3D printing, rapid prototyping and various local northern clean energy sources - allowed a return of agro-business to the region.

Here in Fort McVegan, all that is left over is converted to feed cows in various stations across the region. Cows are employed for casual strolls in hä-häs. The open fields in which the cows go for daily strolls slowly transform into good fertile land. Series of conveyor belts are placed on the inner side below ground level, forming a boundary to the new landscape without interrupting the view. The belts collect the fresh manure produced by cows and send it to nearby digestion chambers to produce biogas that 
fuels the city and connects every BBQ restaurant with a biogas piping system. This also helps to fuel the green houses for Alberta's vegatopia.

Before entering the digester, manure is heated to 100 degrees Fahrenheit, the perfect temperature to prime the appetite of picky microorganisms. Pistons push the hot manure into the main chamber where the microorganisms feast. "The manure breaks down into a biogas bubble and a mixture of solids and liquids. The bubble, mostly methane gas, can be harnessed and used to fuel an engine and generate electricity."59

The new economy of survival for Alberta depends on Modular Building Technology; a form blistered with micro barn-Barnacles that contains clean soil for the growing of crops and the rearing of animals to provide food, wool, and other products. In an ironic way, abandoned factories and oil and gas refineries are being converted into new warehouses with smart energy harvesting facilities such as anaerobic digestion systems. Far from the glamour of the oil paradise, Fort McVegan has drastically changed the lives of every citizen.

The domestic scale of this new territory and its techno-science advancements can coexist with living spaces, promoting a return to the Deutscher Werkbund model of 19th Century Germany, henceforth promoting the Homo Faber movement with the 'agricultural city' as the result, a genuinely mixed-use fruitful place with an identity. 
Pollution, toxic waste and other externalities were completely eliminated and by the early 2020s suburbia had become light space frame farming zones. Alberta became a thriving agricultural center, albeit on a domestic scale, as ordinary people were able to produce small quantities of dairy products from their backyard, or send their herd to mass-manufacture hubs supported by logistic networks of delivery vans and trains.

The prefab lightweight rigid structure is constructed using interlocking braces in a geometric pattern with networked soil sensors to signal how much fertilizer and water are needed and when. The base of the structure has seeds imbedded on surface with microbes that pull nitrogen from the air to boost yields while leaving soil healthier. Charcoal made from waste is added to all soil planters and provides vital nutrients and reduces carbon.

Hereafter Space-frame farming became the way of living on this part of the planet, in the context of the acceleration of techno-scientific mutations and of considerable demographic growth. The space frame farm serves and maintains the desired distance between the contaminated landscape and the 789-D suburbia, all while allowing both sides to share the joy of the zero carbon society. The farm houses the mutual dream of Capitalism and Brothers Farmers Alliance. 


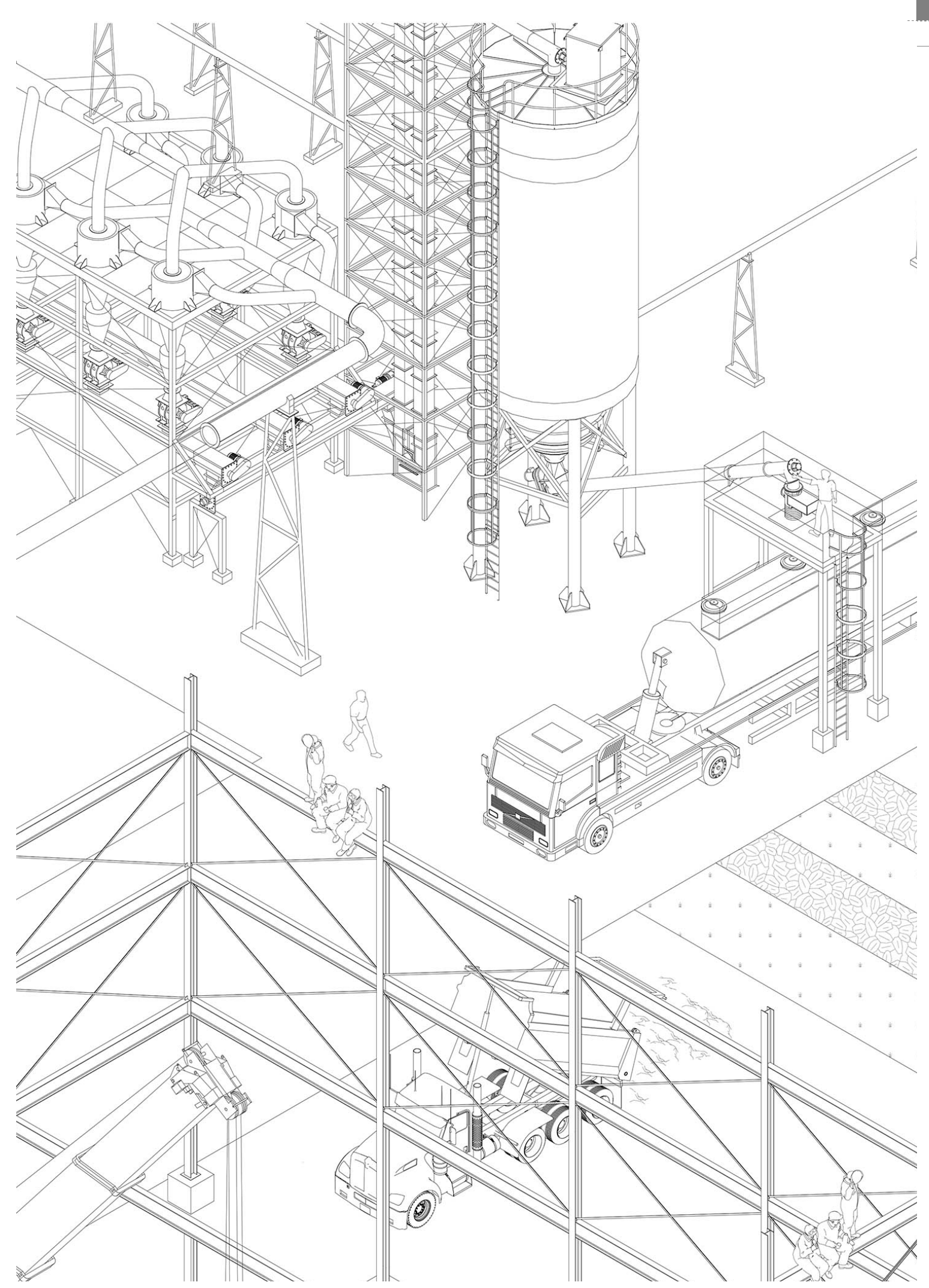




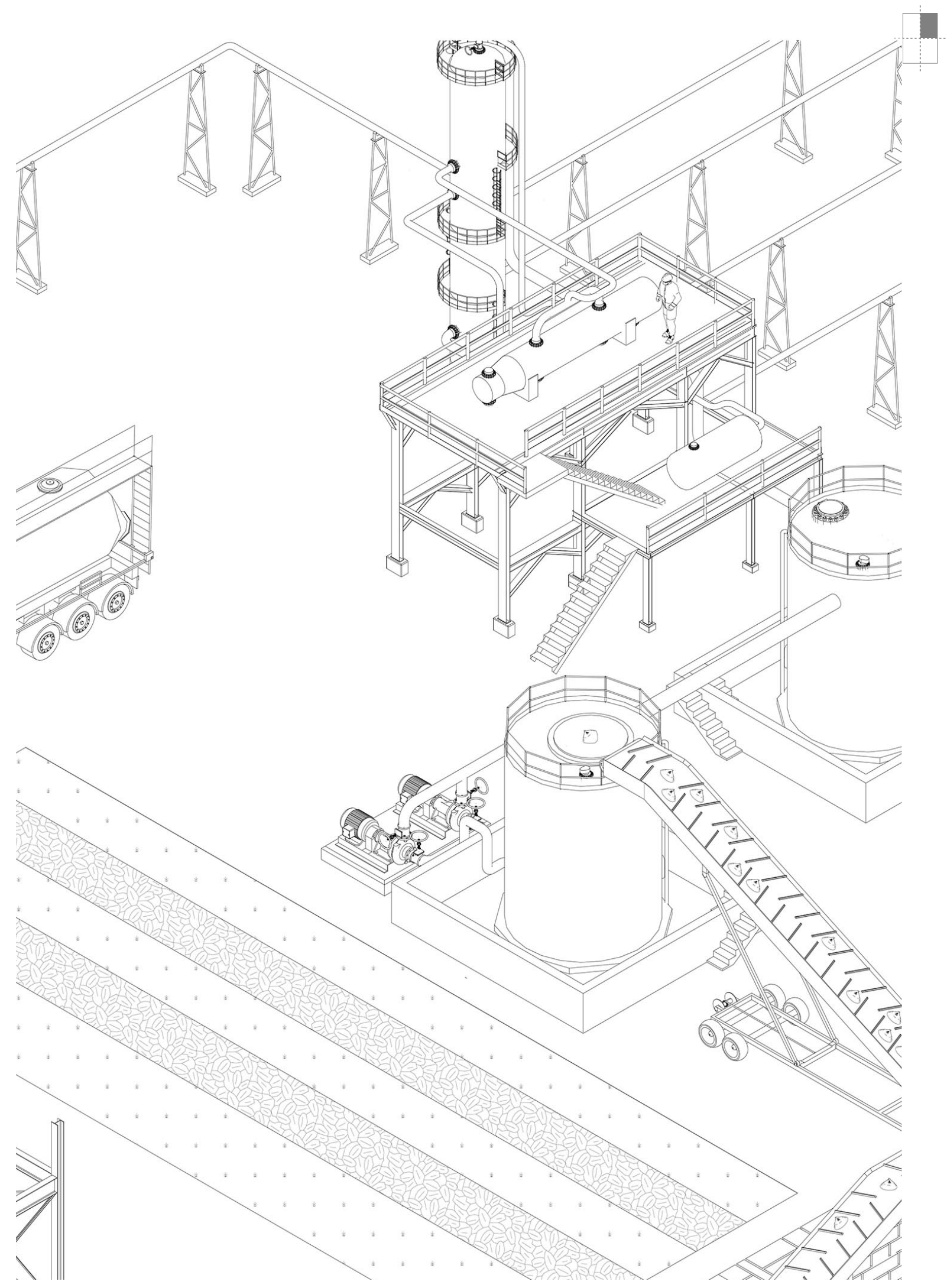




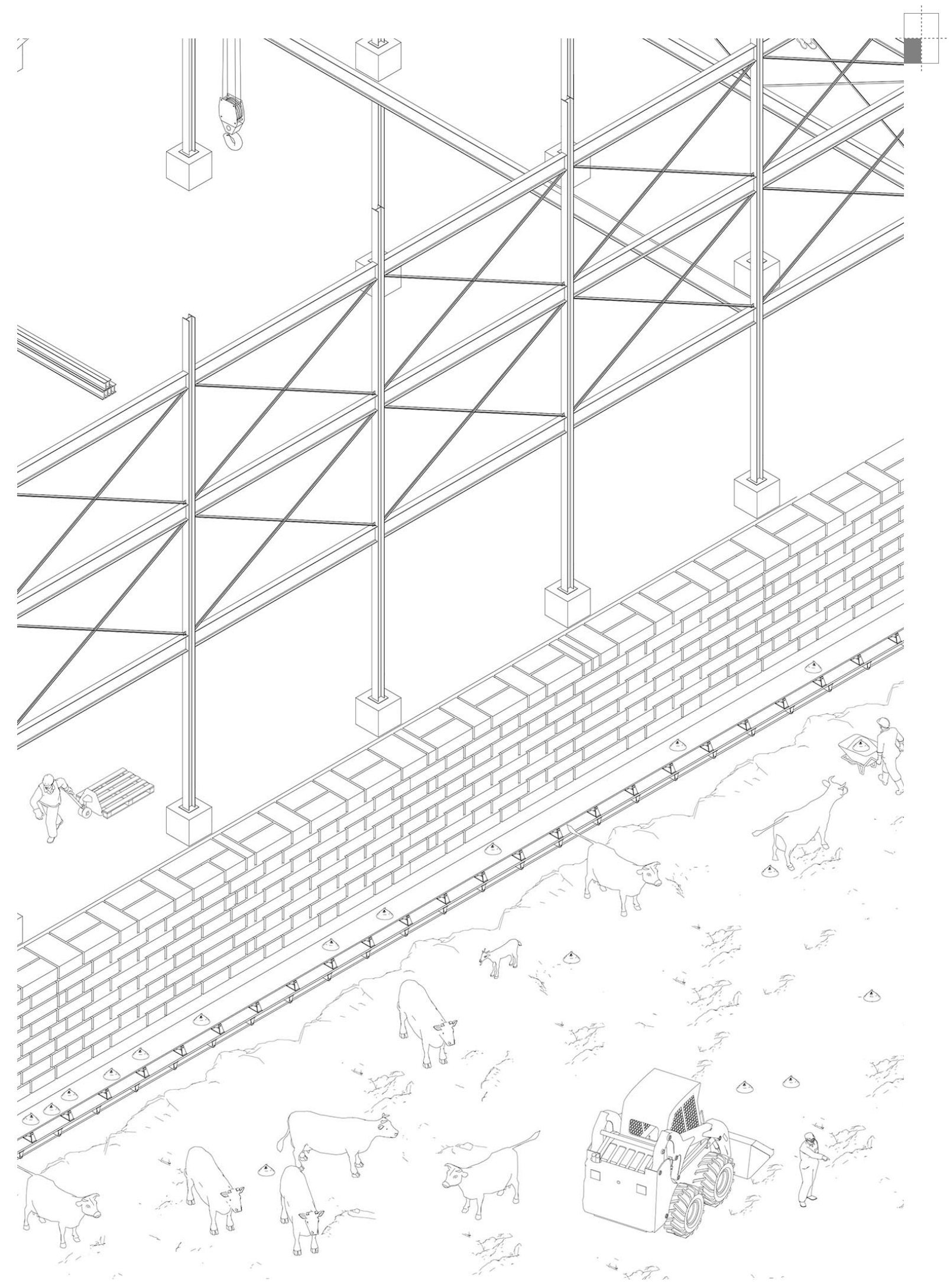




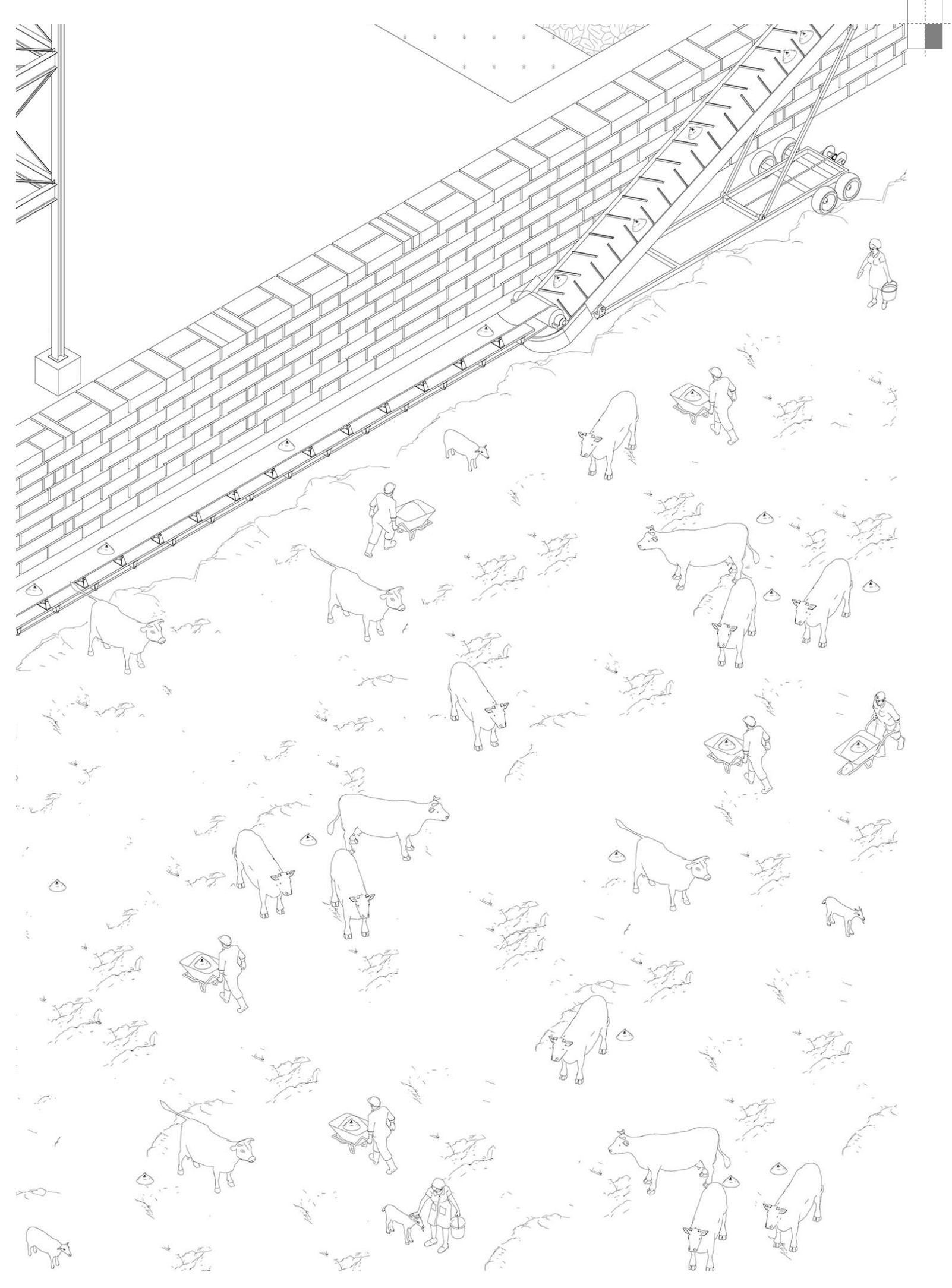




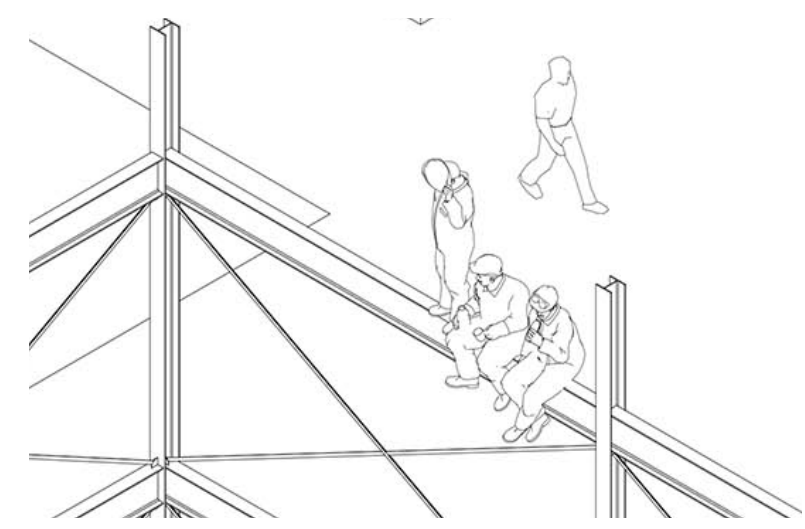




\title{
EXPERIMENTAL UTOPIA
}

TYPE 6

BELIEVERS

\section{PROJECT: POST-URBAN PLAYGROUNDS}

\author{
Text Inspired by \\ Icelandic Lessons \\ Gugger, Harry. Icelandic Lessons: Industrial Landscape. \\ Teaching and Research in Architecture. Park Books, 2016.
}

Imagining Utopia, Tomorrowland, Walt Disney Pictures

Oliver Zeller, MARK Magazine \#56 - June/July 2015

Imagining Utopia (Scott Chambliss/Syd Mead Interview on

Tomorrowland) https://dl.dropboxusercontent.com/u/388102/

M56_Tomorrowland.pdf 


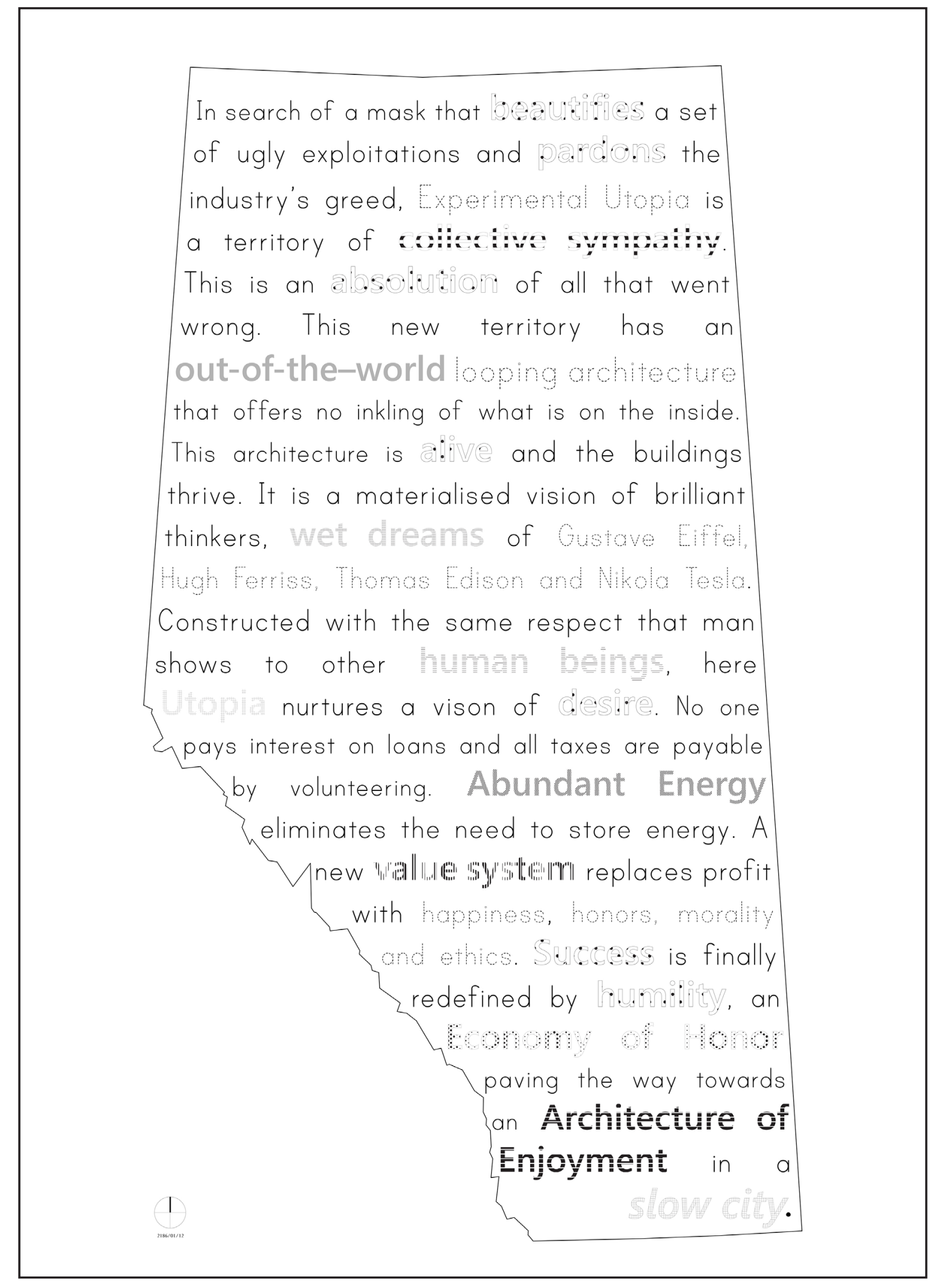




\section{EXPERIMENTAL UTOPIA}

In search of a mask that beautifies a set of ugly exploitations and pardons the industry's greed, Experimental Utopia is a territory of collective sympathy. This is an absolution of all that went wrong. This new territory has an out-of-the-world looping architecture that offers no inkling of what is on the inside. This architecture is alive and the buildings thrive. It is a materialized vision of brilliant thinkers, wet dreams of Gustave Eiffel, Hugh Ferriss, Thomas Edison and Nikola Tesla. Constructed with the same respect that man shows to other human beings, here Utopia nurtures a vision of desire. No one pays interest on loans and all taxes are payable by volunteering. Abundant Energy eliminates the need to store energy. A new value system replaces profit with happiness, honours, morality and ethics. Success is finally redefined by humility, an Economy of Honor paving the way towards an Architecture of Enjoyment in a slow city. 


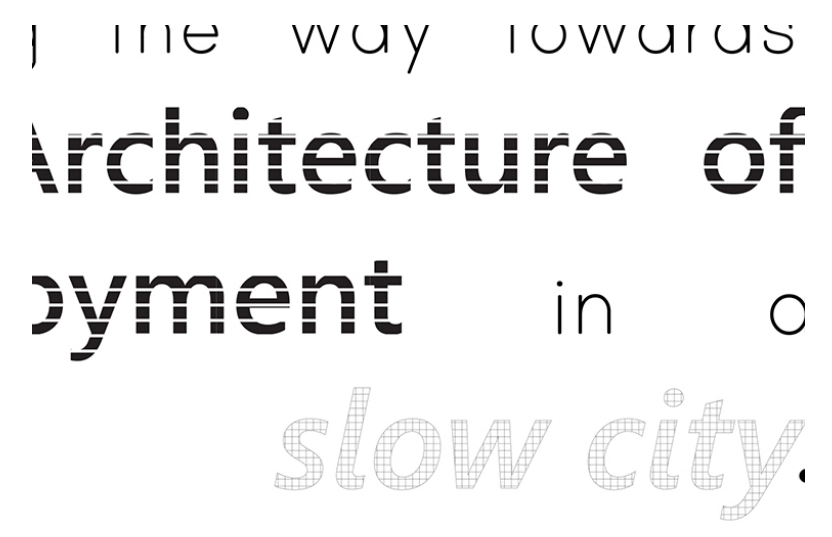




\begin{abstract}
A CRITICAL POST-SCRIPT
Philosopher Ralph Waldo Emerson labelled nature as those "essences unchanged by man; space, the air, the river, the leaf". We must reject the common assumption that human industry can only destroy the environment. Canada's Great White North seems to be one of the last places on Earth still wild, unspoiled and innocent. Although the global scale of our ecological interconnection proves that this perception is merely an illusion, Northern Canada nevertheless offers an ideal setting for a critical staging of the old clash between lush landscape and voracious industry.
\end{abstract}

The drawings illustrate architectural designs produced as critical syntheses of analysis and commentary in response to the core themes. The drawings explore the intersection between industrial aesthetic and ecological environments, and interrogate the ambiguous limits between abstraction and representation, the artificial and the natural, the generic and the vernacular, the formal object and the landscape system. The drawings propose an alternative perspective with respect to the traditional opposition of industry and nature by replacing conflict with responsibility.

In this speculative activist architectural project, the factual is replaced by the fictional. Thus, all that is left is sci-fi-data from real people, places and things. Here Alberta is presented with a certain level of cleanliness and excessive (ab) use of architectural representation, suggesting an exasperating aspiration to find order in the current chaotic orgy of production and immorality. 
Post Petropolis illustrated the topography of a new Alberta. The tension between the dirty realities of the current landscape of Alberta and the false purity of this thesis allows the research to use visual schemes that otherwise would tend to incorporate more than a hint of emotions. Looking at typical places/landscapes like roads, factories, parks, suburbs, Post-Petropolis has taken us through a sequence of influential and omnipresent experiences in the six new territories. Hopefully we transcend from the amusing to the virtuously descriptive, from the ordinary to the garish, yet always hinting to a moment of awareness.

There is an overarching stress between the pure line drawings and specific site locations of each territory, connoting general architectural plans for a potential site of construction; they are fragments of a non-linear unending narrative.

To conclude this phantasmagoria (Petropolis) - though fictional - is appropriate and relevant. It promotes a powerful and frightening spirit in Alberta. Post Petropolis is an imaginarium for Alberta's landscape and oil economy where fictional narrative is used to explore, discover and invent unique realities within which new ecologies of hope are sited.

Is there any longing for survival? 
Planning is the only way forward for Alberta. Ecology means planning. Ecology is not only a technological issue it is also an anthropological issue. If the world's population became vegetarian today, 30\% of our current environmental problems would be solved. Today's techno-scientific illusions yield no solution. Solar panels, eco-friendly coffee cups and hybrid SUVs will not save the planet. The problem is us: the way we behave, the way we demand, produce, transport and consume. "Ecology is no novelty!" and through the lenses of technology and science these changes are nothing new. Architects and urban designers have been well aware of eco-systems since the 1970s, if not before. Nevertheless, ecology is still largely ignored, mainly due to the kevorkianesque logic of the free market.

This thesis is not arguing for or against sustainable living; rather what this research has uncovered is how difficult it is to take any responsibility. Taking responsibility is not easy, no doubt. The research here aims to reach a different constituency, not just the general public. Returning to Newton's Third Law, we can now experience first-hand some serious reaction to some very poor planning actions that designers, planners and governments have been making for centuries.

It is not hard to imagine where we are going if we continue planning, producing and consuming in the same vein. In fact the six parts fairy-tale is an attempt to invade the future of petroleum dependent regions such as northern Alberta that are trapped in the perpetual darkness of short-term planning. 
Again, this thesis does not intend to provide an architectural solution per se, but rather proposes a sincere discussion and aims to inform and invite the authorities at all levels to take responsibility. Not just the authorities, all of us, designers, citizens, politicians, professors. If we want change we must act, otherwise all Eco-green awareness is pointless. What do we want to save in Alberta and why? 


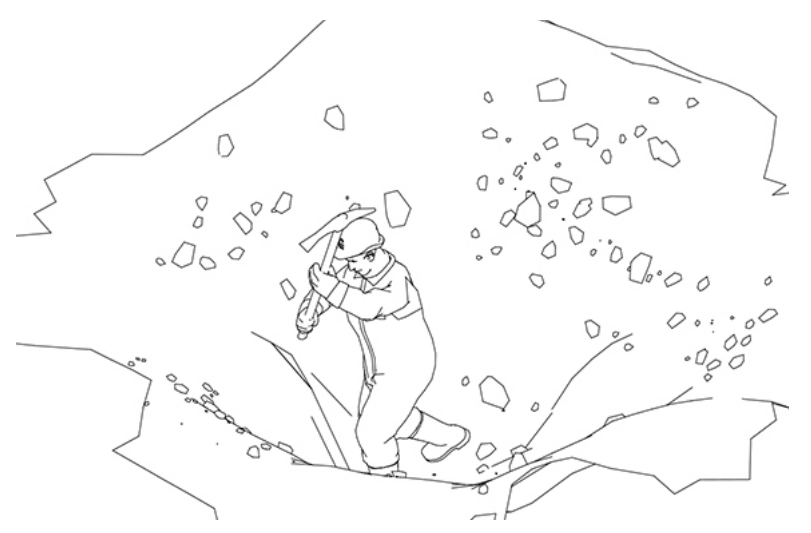




\section{ENDNOTES}

1. J. G Ballard's Notes in the The Atrocity Exhibition provide a narrative structure of his novel. London: Flamingo, 2001.

2. Ed Begley, "Overpopulation, overconsumption - in pictures". The guardian, 2015.

3. Some context ideas are driven from Pezzullo Phaedra C, "Tourist Itineraries." In Toxic Tourism Rhetorics of Pollution, Travel, and Environmental Justice (Tuscaloosa: University of Alabama Press, 2007). And Andrew Blackwell, "The Great Black North." In Visit Sunny Chernobyl: And Other

Adventures in the World's Most Polluted Places (New York: Rodale, 2012), 47.

4. Tom Goodman-Hill, Mega structures Ultimate Oil Sands Mine, National Geography, 2005, Youtube, Posted by, RandomLTU. 01:01, 2005. https://www.youtube.com/watch?v=nFBXQCBG3DA

5. GEORGE H. LA ROI, "Boreal Forest." Historic Canada, April 3, 2015, http://www.thecanadianencyclopedia.ca/en/article/boreal-forest.

6. "Oil Sand Overview." Facts about Alberta's Oil Sands and Its Industry, 2015. http://history.alberta.ca/oilsands/resources/docs/facts_sheets09. pdf.

7. Eric Reguly, "PETRO-STATE: CANADA." Beautiful Destruction, Rocky Mountain Books, 2006. 95

8. Ibid.

9. Bob Weber "Alberta Government Not Doing Enough About High Oilsands Emissions: Critics." HUFFPOST ALBERTA, 2014.

10. Ibid.

11. Responsible Canada Energy, CAPP 2014 Progress Report, 12

12. Canada pulls out of Kyoto Protocol. CBC News, 2011, http://www.cbc.ca/news/politics/canada-pulls-out-of-kyoto-protocol-1.999072.

13. Ibid.

14. Reguly, "PETRO-STATE: CANADA,"95.

15. Ibid.

16. Ibid.

17. William Marsden, Stupid to the Last Drop: How Alberta Is Bringing Environmental Armageddon to Canada (and Doesn't Seem to Care), Toronto, Alfred A. Knopf, 2007.

18. Blackwell, "The Great Black North." In Visit Sunny Chernobyl, New York: Rodale, 2012. 42.

19. Reguly, "PETRO-STATE: CANADA,"95

20. Cepeda Raquel, "Picture Quotes", 2015, http://www.picturequotes.com/paradise-is-a-state-of-being-more-than-just-the-name-of-a-suburbor-a-home-quote-227766.

21. "Mega trucks," History Chanel, 2015, Online Archive, http://www.history.com/shows/rise-of-the-machines/videos/rise-of-the-machines-megatruck,

22. "789D." Off-Highway Trucks, 2015, http://www.cat.com. 
23. Smil Vaclav, 'World History and Energy', Encyclopedia of Energy, Vol. 6, 2004 Elsevier Inc, 557.

24. Samuel Alexander, Peak Oil, Energy Descent, and the Fate of Consumerism, 2012, http://ssrn.com/abstract=1985677 or http://dx.doi. org/10.2139/ssrn. 1985677

25. Ibid.

26. Mike Hudema, Climate and Energy Campaigner. Greenpeace Canada. July 15, 2014 Edmonton, Alberta.

27. Os, Will. "Dystopia". University of Anarchists, 2015, http://pandora.library.uanatcist.com/node/557).

28. Walter Gropius "Programme of the Staatliches Bauhaus in Weimar." Cambridge, Mass.: MIT Press, 1971. 50.

29. Lara Schrijver, docutopia, Catalogue to the exhibition COMING SOON. Bureau Europa, 2014.

30. Ibid.

31. Ibid.

32. Sir Thomas More's Utopia, Utopia an imaginary island described in (1516) as enjoying perfection in law, politics, Dictionary.com. Dictionary com Unabridged. Random House, Inc. http://dictionary.reference.com/browse/utopia. 2015.

33. Ibid.

34. Ibid.

35. Jonathan Cary, 24/7 Late Capitalism and the End of Sleep, London: VERSO, 2013

36. Ibid.

37. Ibid.

38. Doona Bae, Cloud, Atlas, Doona Bae as Tilda the Sonmi Prostitute. Warner Bros Entertainment, Australia, 2012. Film.

39. Rumi, Jalāl ad-Dīn Muhammad Rūmī. Ezak, Awuna. "Who Is Talking To HU!: The true story of Shamsi Tabriz and Rumi" google books.

40. Pyramid. пupapic, Henry George Liddell, Robert Scott, A Greek-English Lexicon, on Perseus Digital Library, Oxford. Clarendon Press. 1889.

41. "Sulfur", The Sulfur Industry, http://www.sultran.com/sulphur.aspx October 18, 2015

42. Dani Punjalte and Rita Puig-Serra, Breathing in the dust of the world, Too Much, Issue 6, Editions OK FRED, 2015, 65.

43. Sulfur." The Canadian Encyclopedia. Accessed October 18, 2015

44. Andrew David Thaler, Alberta, Canada is the proud owner of the largest man-made pyramid on the planet, Southern Fried Science, October 18, 2012. http://www.southernfriedscience.com/alberta-canada-is-the-proud-owner-of-the-largest-man-made-pyramid-on-the-planet/

45. Blackwell, "The Great Black North." In Visit Sunny Chernobyl, New York: Rodale, 2012. 48.

46. Cori O'Donnell, "Sulfur Piles Larger than Buildings," 2015. http://www.energyandcapital.com/articles/sulphur-piles-larger-than-bulidings/1815. 
47. Ibid.

48. Rumi, Jalāl ad-Dīn Muhammad. khamush. http://www.khamush.com/life\&death.htm.

49. Johnson, Kevin P. Sorenson, Michael D. Kevin P. Sorenson, Michael D. "Phylogeny and biogeography of dabbling ducks, 1999.

50. Robin Baker "Birds." In The Mystery of Migration, Wiley Publication of Canada, 1980. 148.

51. Shmoop Editorial Team. "Threats to Biodiversity: Invasive Species - Shmoop Biology." 2008. http://www.shmoop.com/conservation-biology/ threats-invasive-species.html.

52. "1980s Bumper Sticker." Canada.com, http://www.canada.com/calgaryherald/news/story.html?id=042ce381-9138-4dc7-b358-372a4b0a47744.

53. Bhatia, Neeraj. The Petropolis of Tomorrow. Edited by Mary Casper. New York, NY: Actar D, 2013

54. Stephen Leeb,. "Moving Beyond Oil." In The Oil Factor: Protect Yourself-and Profit-from the Coming Energy Crisis, New York, N.Y.: Warner Business Books, 2004. 73.

55. Naomi Klein, shock doctrine - shock dogma - A GREAT DOCUMENTARY 49:56 ttps://www.youtube.com/watch?v=QxxOlfrtYYY

56. Ibid.

57. TWT constructions are inspired by Hoffmann's constructed wetlands. Hoffmann. H., Platzer, C., von Münch, E., Winker, M. (2011): Technology review of constructed wetlands - Subsurface flow constructed wetlands for grey water and domestic wastewater treatment. Deutsche Gesellschaft für Internationale Zusammenarbeit (GIZ) GmbH, Eschborn, Germany.

58. Barbieri, A., Garuti, G., Avolio, F., Bruni, S., 2003. Sludge dewatering using macrophytes in a small wastewater treatment system: a case study of a pilot scale plant in Northern Italy. Journal of Environmental Science and Health. Part A, Toxic/Hazardous Substances \& Environmental Engineering 38 (10), 2425-2433.

59. Sanborn, Sarah. "Harnessing The Hidden Power of Cow Manure"

60. Ralph Waldo Emerson, and David Mikics. The Annotated Emerson. Cambridge, MA: Belknap Press of Harvard University Press, 2012 


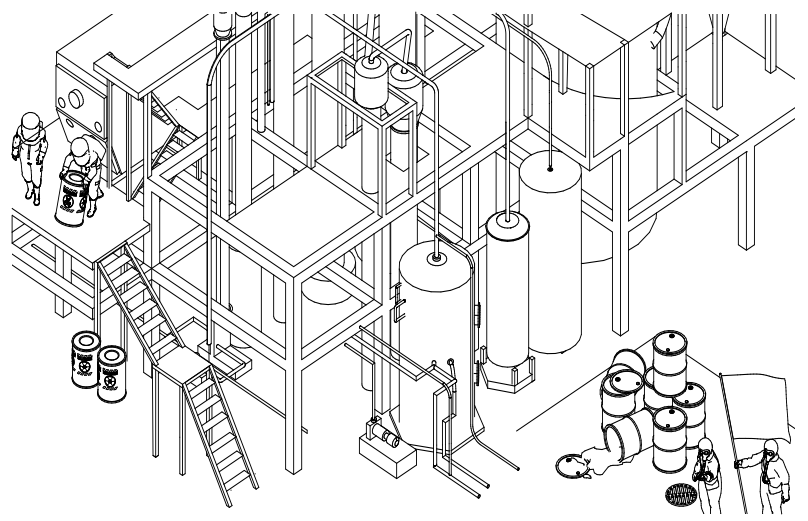




\section{BIBLIOGRAPHY}

"789D." Off-Highway Trucks, October 18, 2015. "789D." OFF-HIGHWAY TRUCKS. Accessed October 18, 2015. http://www.cat.com.

Alexander, Samuel. Peak Oil, Energy Descent, and the Fate of Consumerism (January 15, 2012). Available at SSRN: http://ssrn.com/abstract=1985677 or http://dx.doi.org/10.2139/ssrn.1985677.

Aureli, Pier Vittorio, and Martino Tattara. Dogma: 11 Projects. Edited by Gabriele Mastrigli. 1st ed. London: AA Publications, 2013.

Bae, Doona. Cloud Atlas. Directed by Tom Tykwer. Germany / USA / Hong Kong / Singapore: Distributed by Warner Bros. Entertainment Australia, 2012. Film.

Baker, Robin. "Birds." The Mystery of Migration, 148. Ontario: Wiley Publication of Canada Limited, 1980.

Ballard, J. G The Atrocity Exhibition. London: Flamingo, 2001.

Barbieri, A., Garuti, G., Avolio, F., Bruni, S., 2003. Sludge dewatering using macrophytes in a small wastewater treatment system: a case study of a pilot scale plant in Northern Italy. Journal of Environmental Science and Health. Part A, Toxic/Hazardous Substances \& Environmental Engineering 38 (10), 2425-2433.

Baudrillard, Jean. The Consumer Society Myths and Structures. Thousand Oaks, CA: Sage Publications, 2008

Begley, Ed. Overpopulation, overconsumption - in pictures. The guardian, 2015. http://www.theguardian. com/global-development-professionals-network/gallery/2015/apr/01/over-population-over-consumptionin-pictures. (Accessed Jan 14, 2015).

Berkman, Alexander. What Is Anarchism? Edinburgh, Scotland: AK Press, 2003.

Bhatia, Neeraj. The Petropolis of Tomorrow. Edited by Mary Casper. New York, NY: Actar D, 2013

Blackwell, Andrew. Visit Sunny Chernobyl: And Other Adventures in the World's Most Polluted Places. New York: Rodale, 2012.

Bookchin, Murray. Post-scarcity Anarchism. Edinburgh: AK Press, 2004.

Brooks, Max. The Zombie Survival Guide: Complete Protection from the Living Dead. New York: Three Rivers Press, 2003.

"1980s Bumper Sticker." Canada.com, http://www.canada.com/calgaryherald/news/story.html?id=042ce3819138-4dc7-b358-372a4b0a4774 (accessed Jan 15, 2016)

Canada pulls out of Kyoto Protocol. CBC News Posted: Dec 12, 20114:00 PM ET Last Updated: Dec 13, 2011 7:57AM. http://www.cbc.ca/news/politics/canada-pulls-out-of-kyoto-protocol-1.999072.

Chang, Michael I. Pollution in China. New York: Nova Science Publishers, 2011.

Crary, Jonathan. 24/7: Late Capitalism and the Ends of Sleep. London: VERSO, 2013.

Corner, James. Recovering Landscape: Essays in Contemporary Landscape Architecture. New York: Princeton Architectural Press, 1999. 
Diken, Bülent. Nihilism. Milton Park, Abingdon, Oxon: Routledge, 2009.

Emerson, Ralph Waldo, and David Mikics. The Annotated Emerson. Cambridge, MA: Belknap Press of Harvard University Press, 2012.

Ghidoni, Matteo. SAN ROCCO . ECOLOGY, October 1, 2014.

Goodman-Hill, Tom. "Mega structures." Ultimate Oil Sands Mine, National Geography, Youtube, Posted by, RandomLTU. 01:01, 2005. https://www.youtube.com/watch?v=nFBXQCBG3DA.

Golding, William. Lord of the Flies: A Novel. London: Faber and Faber, 1958.

Gregotti, Vittorio. Inside Architecture. Chicago, IL: Graham Foundation for Advanced Studies in the Fine Arts, 1996.

Gropius, Walter. "Programme of the Staatliches Bauhaus in Weimar." In Programs and Manifestoes on 20thcentury Architecture, edited by Ulrich Conrads, 50. Cambridge, Mass.: MIT Press, 1971.

Hands, Tatum L., ed. Pleasure-Interdisciplinary Journal of Landscape Architecture. Vol. 02. ORO Editions, 2015.

Herber, Lewis. Post-scarcity Anarchism. Berkeley: Ramparts Press, 1971.

H. LA ROI, GEORGE. "Boreal Forest." Historic Canada. April 3, 2015. Accessed October 18, 2015. http://www. thecanadianencyclopedia.ca/en/article/boreal-forest.

Hoffmann. H., Platzer, C., von Münch, E., Winker, M. (2011): Technology review of constructed wetlands - Subsurface flow constructed wetlands for grey water and domestic wastewater treatment. Deutsche Gesellschaft für Internationale Zusammenarbeit (GIZ) GmbH, Eschborn, Germany.

Hollier, Denis. Against Architecture: The Writings of Georges Bataille. Cambridge, MA: MIT Press, 1989.

Hudema, Mike, Climate and Energy Campaigner. Greenpeace Canada. July 15, 2014 Edmonton, Alberta.

Ibañez, Daniel, and Nikos Katsikis. Grounding Metabolism. Cambridge by Universal Wilde, 2014.

Johnson, Kevin P. Sorenson, Michael D. Kevin P. Sorenson, Michael D. (1999). "Phylogeny and biogeography of dabbling ducks (genus Anas): a comparison of molecular and morphological evidence" (PDF). The Auk 116 (3): 792-805. doi:10.2307/4089339. Retrieved 13 December 2015.

Lambert, Leopold. The Beginning of the End of the Beginning. In Too Much: Magazine of Romantic Geography, Tokyo: Editions OK FRED, 2015.149.

Leeb, Stephen, and Donna Leeb. "Moving Beyond Oil." In The Oil Factor: Protect Yourself and Profit from the Coming Energy Crisis, New York, N.Y.: Warner Business Books, 2004. 73.

Lefebvre, Henri, Łukasz Stanek, Robert Bononno, and Henri Lefebvre. Toward an Architecture of Enjoyment. University of Minnesota Press. 2014. 
Len Garth. "The true cost of oil," TEDxVictoria, 17:40, November,2011, Transcribed by Morton Bast https:// www.ted.com/talks/garth_lenz_images_of_beauty_and_devastation/transcript?language=en.

Locher, Maria, ed. Dream of Building or the Reality of Dreaming: Checking the Pulse of Design Build Bluff Practices. University of Utah, 213.

Marsden, William. Stupid to the Last Drop: How Alberta Is Bringing Environmental Armageddon to Canada (and Doesn't Seem to Care). Toronto: Alfred A. Knopf, 2007.

Mathur, Anuradha, Dilip Da Cunha, and Anuradha Mathur. Design in the Terrain of Water. United States: Applied Research Design Publishing, 2014.

"Mega trucks," History Chanel. October 17, 2015. "Mega trucks." History Chanel. March 11, 2014. http:// www.history.com/shows/rise-of-the-machines/videos/rise-of-the-machines-mega-truck.

McLuhan, Marshall, and Wilfred Watson. From Cliche to Archetype. New York: Viking Press, 1970.

More, Sir. Thomas. Utopia, Dictionary.com. Dictionary.com Unabridged. Random House, Inc. http:// dictionary.reference.com/browse/utopia (accessed: November 11, 2015).

Murphy, Douglas. Last Futures Nature, Technology and the End of Architecture. New York: Verso, 2016.

Nye, David E. Technologies of Landscape from Reaping to Recycling. Amherst: University of Massachusetts Press, 1999.

Kim, Janette, and Erik Carver. The Underdome Guide to Energy Reform. New York: Princeton Architecture Press, 2015.

Klein, Naomi. No Logo: No Space, No Choice, No Jobs. London: Flamingo, 2000.

Klein, Naomi. shock doctrine - shock dogma - A GREAT DOCUMENTARY 49:56. Youtube, Posted by Stelios Pafios. https://www.youtube.com/watch?v=QxxOlfrtYYY.

Kovel, Joel. The Enemy of Nature: The End of Capitalism or the End of the World? London: Zed Books, 2002.

O'Donnell, Cori. "Sulfur Piles Larger than Buildings," Energy and Capital. Posted October 5, 2011. http://www. energyandcapital.com/articles/sulphur-piles-larger-than-bulidings/1815.

"Oil Sand Overview." Facts about Alberta's Oil Sands and Its Industry: 12. Accessed October 18, 2015. http:// history.alberta.ca/oilsands/resources/docs/facts_sheets09.pdf.

Orwell, George. Nineteen Eighty Four. St Ives: Penguin Books, 1987.

Partanen, Rauli, Harri Paloheimo, and Heikki Waris. The World after Cheap Oil. New York: Routledge, 2015.

Os, Will. "Dystopia". University of Anarchists. http://pandora.library.uanatcist.com/node/557 (accessed Jan 14, 2015).

Phaedra C, Pezzullo. "Tourist Itineraries." In Toxic Tourism Rhetorics of Pollution, Travel, and Environmental Justice. Tuscaloosa: University of Alabama Press, 2007. 
Pyramid. тupauic, Henry George Liddell, Robert Scott, A Greek-English Lexicon, on Perseus Digital Library, Oxford. Clarendon Press. 1889.

Punjalte, Dani. Puig-Serra, Rita. Breathing in the dust of the world,. Too Much, Magazine of Romantic Geography. Issue 6, Editions OK FRED, Summer 2015. 65

Raquel, Cepeda. "Picture Quotes". http://www.picturequotes.com/paradise-is-a-state-of-being-more-thanjust-the-name-of-a-suburb-or-a-home-quote-227766 (accessed Jan 14, 2015).

Responsible Canada Energy, CAPP 2014 Progress Report, 12. http://www.capp.ca/ /media/capp/customerportal/publications/255363.pdf.

Reguly, Eric. Helbig, Louis. "PETRO-STATE: CANADA." Beautiful Destruction. Rocky Mountain Books, 2006. 95.

Rumi, Jalāl ad-Dīn Muhammad. khamush. http://www.khamush.com/life\&death.htm (accessed Jan 14, 2016).

Sanborn, Sarah. "Harnessing The Hidden Power of Cow Manure." Kqed-science. August 29, 2013. Accessed March 15, 2016. http://ww2.kqed.org/quest/2013/08/29/harnessing-the-hidden-power-of-cow-manure/.

Schrijver, Lara. docutopia, Catalogue to the exhibition COMING SOON. Bureau Europa, 2014.

Scruton, Roger. Green Philosophy: How to Think Seriously about the Planet. London: Atlantic Books, 2012.

Shiva, Vandana. Soil Not Oil: Environmental Justice in a Time of Climate Crisis. Cambridge, MA: South End Press, 2008.

Shmoop Editorial Team. "Threats to Biodiversity: Invasive Species - Shmoop Biology." Shmoop.com. November 11, 2008. Accessed December 12, 2015. http://www.shmoop.com/conservation-biology/threatsinvasive-species.html.

"Sulfur." The Canadian Encyclopedia. Accessed October 18, 2015.

"Sulfur", The Sulfur Industry, http://www.sultran.com/sulphur.aspx October 18, 2015.

Thaler, Andrew David. Alberta, Canada is the proud owner of the largest man-made pyramid on the planet, Southern Fried Science, October 18, 2012. http://www.southernfriedscience.com/alberta-canada-is-theproud-owner-of-the-largest-man-made-pyramid-on-the-planet. Accessed October 18, 2015.

Vaclav, Smil, 'World History and Energy' in C.Cleveland (ed), Encyclopedia of Energy, Vol. 6 (2004) Elsevier Inc. 557.

Weber, Bob. "Alberta Government Not Doing Enough About High Oilsands Emissions: Critics." HUFFPOST ALBERTA, August14, 2014.

Wingårdh, Gert, and Rasmus Wærn. Crucial Words: Conditions for Contemporary Architecture. Basel: Birkhäuser, 2008.

Wood, Jeff. The Glacier: A Cinematic Novel. Two Dollar Radio, 2015. 


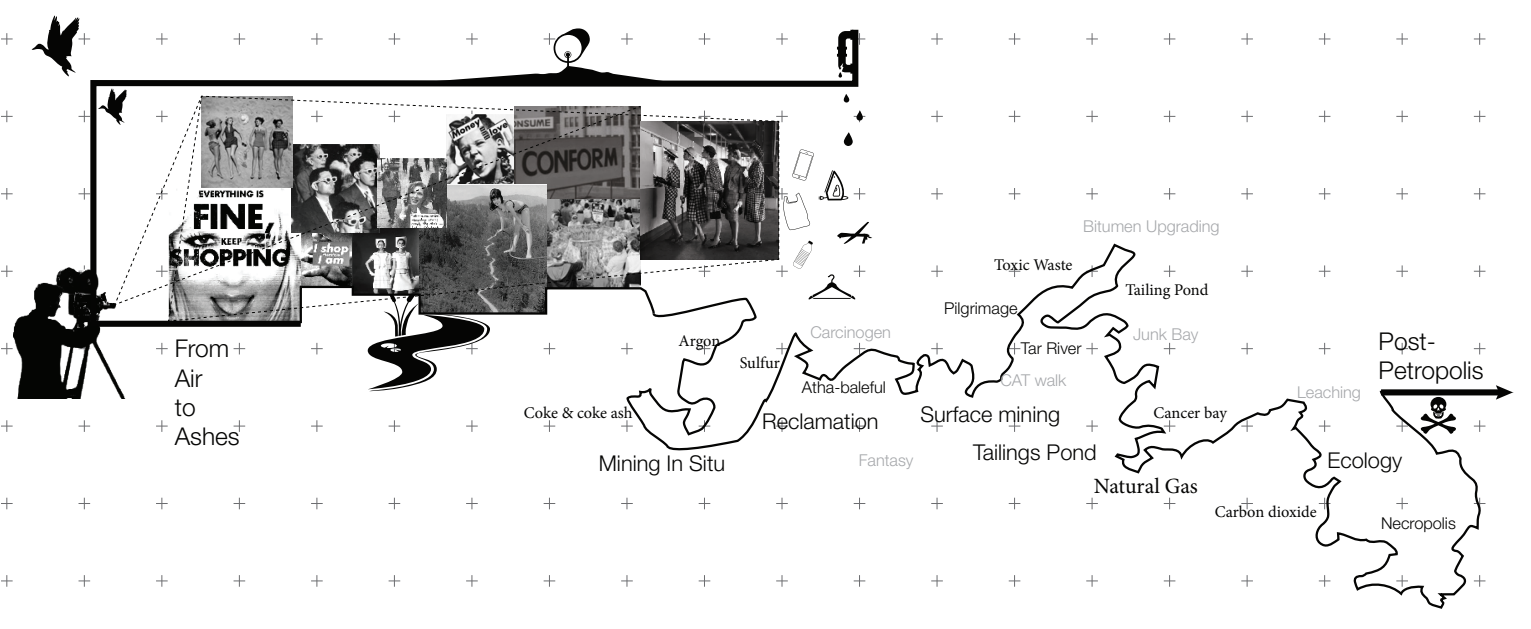

